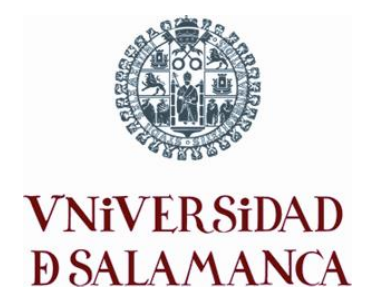

Facultad de Medicina

Departamento de Anatomía e Histología Humanas

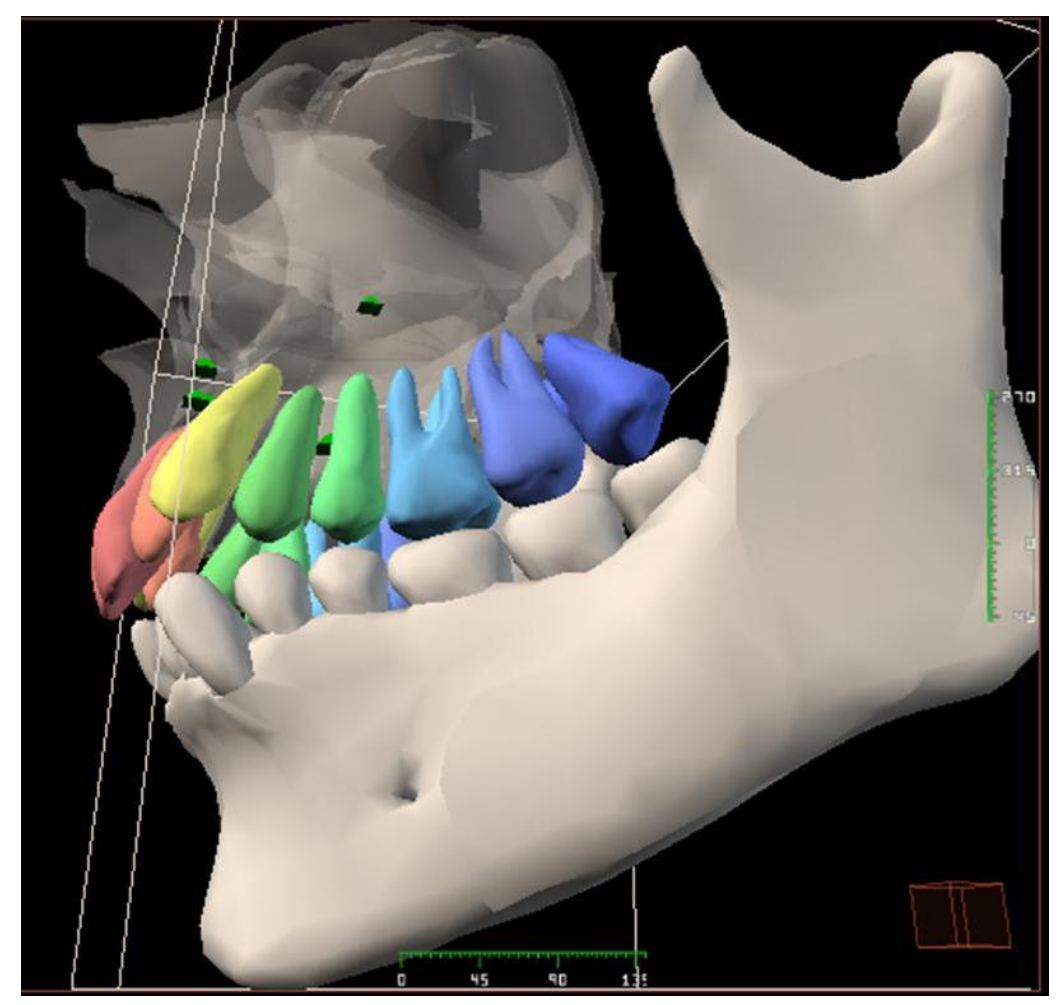

\title{
ENTORNO VIRTUAL DE VISUALIZACIÓN ANATÓMICA DEL APARATO DENTARIO, TRAS SU MODELADO TRIDIMENSIONAL CON TÉCNICAS RADIOLÓGICAS
}

\section{Laura Rubio Martín}

Tesis Doctoral

Salamanca - 2014 
VNiVERSIDAD

DSALAMANCA

D. JUAN ANTONIO JUANES MÉNDEZ Y D. MANUEL RUBIO SÁNCHEZ, DOCTORES EN MEDICINA Y CIRUGÍA, PROFESORES DEL DEPARTAMENTO DE ANATOMÍA E HISTOLOGÍA HUMANAS DE LA UNIVERSIDAD DE SALAMANCA

\section{CERTIFICAMOS:}

Que el trabajo titulado "ENTORNO VIRTUAL DE VISUALIZACIÓN ANATÓMICA DEL APARATO DENTARIO, TRAS SU MODELADO TRIDIMENSIONAL CON TÉCNICAS RADIOLÓGICAS“, ha sido realizado por Dña. Laura Rubio Martín, bajo nuestra dirección; reuniendo, a nuestro juicio, los requisitos y méritos suficientes para que la autora del mismo, pueda optar al Grado de Doctor por la Universidad de Salamanca.

Y para que así conste, firmamos la presente certificación en Salamanca a treinta de octubre de dos mil catorce. 


\section{Dedicatoria}

A mis padres, mi hermana y mi marido 


\section{ÍNDICE}

1.- Agradecimientos ............................................ 6

2.- Prólogo ..................................................... 9

3.- Introducción ................................................... 11

3.1.- Desarrollo embrionario de los dientes ......................... 12

3.2.- Importancia de la imagen 3D para el diagnóstico clínico y el reconocimiento de estructuras anatómicas........................... 19

3.3.- Papel de las técnicas de imagen diagnóstico para el reconocimiento de estructuras del aparato dentario................... 23

3.4.- La informática en las ciencias de la salud: programas docentes informatizados

4.- Planteamiento del trabajo

5.- Material y Métodos .......................................... 55

5.1.- Material gráfico y documental .................................. 56

5.1.1.- Adquisición y procesamiento de imágenes de tomografía

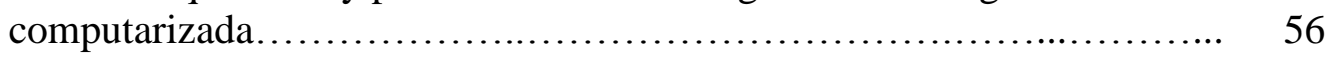

5.1.2.- Modelos 3D ....................................................... 59

5.1.3.- Material documental ................................................ 62

5.2.- Implementación de la aplicación en el visor DirectX............. 63

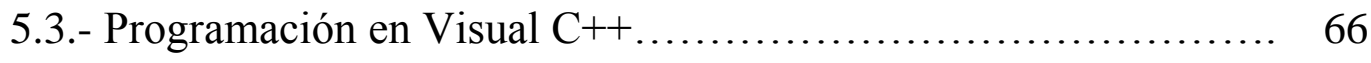

5.4.- Encuesta de satisfacción........................................ 68

6.- Resultados ............................................. 71

6.1.- Maxilar superior........................................ 76

6.2.- Maxilar inferior................................................ 81

6.3.- Aparato dentario.............................................. 85

6.4.- Nervio mandibular.......................................... 108

6.5.- Encuesta de satisfacción.................................... 113 
7.- Discusión ................................................. 116

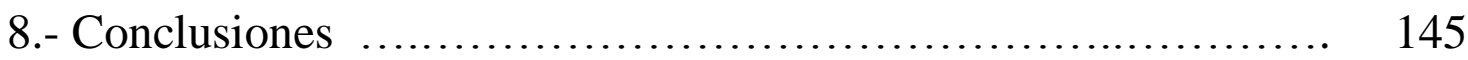

9.- Bibliografía ............................................. 148 
AGRADECIMIENTOS 
Quiero expresar mi más sincero reconocimiento a los Profesores Doctores D. Juan Antonio Juanes Méndez y D. Manuel Rubio Sánchez, de la Universidad de Salamanca, por la magnífica dirección de este trabajo de Tesis Doctoral.

Igualmente, quiero agradecer al Profesor Dr. D. Alberto Prats Galino, de la Universidad de Barcelona, por su gran aportación y ayuda en la ejecución del trabajo informático para el estudio tridimensional de las estructuras anatómicas del aparato dentario.

Mi agradecimiento también al servicio de radiodiagnóstico del Hospital Universitario de Salamanca, por su aportación en la adquisición de las imágenes radiológicas.

Al Dr. José Ignacio Salmerón Escobar, Cirujano maxilofacial del Hospital Gregorio Marañón de Madrid, y al Profesor José Ramón Mérida Velasco, del departamento de Ciencias Morfológicas de la Universidad Complutense de Madrid, por sus contribuciones a este trabajo.

Al personal técnico de la empresa CITEC-B, de Madrid, por la implementación de la aplicación informática.

Deseo hacer extensiva mi gratitud a todos aquellos que de una forma $u$ otra han colaborado en el desarrollo de esta Tesis Doctoral y sobre todo por la cesión de las imágenes radiológicas necesarias para nuestra Tesis.

No puedo dejar de agradecer a mis padres, a mi hermana y mi marido, que al igual que en todos los proyectos de mi vida, han estado ayudando y alentándome para que este trabajo de Tesis también llegara a buen fin. 
A todos mis amigos que, de alguna manera, se interesaron y me alentaron para que esta Tesis fuera terminada.

A todos, muchas gracias. 


\section{PRÓlogo}


Una vez terminada la carrera de Odontología es nuestro sino adentrarnos en el mundo laboral, para poder desarrollar nuestra gran ansiada faceta asistencial y, para ello, durante algún tiempo debimos aislarnos del mundo circundante. Después, tras varios años de dedicación asistencial exclusiva, se me ha brindado la posibilidad de poder empezar a realizar mis primeras incursiones en el terreno de la investigación y de la docencia.

Durante el desarrollo de mi carrera profesional, siempre he tenido especial interés por la labor docente compaginada con la práctica clínica odontológica.

Gracias al Departamento de Anatomía e Histología Humanas de la Universidad de Salamanca, pude conocer diversos proyectos tecnológicos desarrollados en el departamento, uno de los cuales llamó especialmente mi atención y fue motivación suficiente para incorporarme a un proyecto de gran esfuerzo y dedicación que ha culminado con el desarrollo de mi Tesis Doctoral.

Para este proyecto se han necesitado los sistemas más avanzados y de última generación en desarrollo y reconstrucción de imágenes informáticas, lo que ha generado mi necesidad de ampliar conocimientos en otros terrenos tan alejados de la Odontología como tan necesarios y cada día más presentes en nuestra actividad asistencial diaria.

Este trabajo de Tesis Doctoral ha permitido también incentivar mi faceta docente. 
INTRODUCCIÓN 


\section{1.- DESARROLLO EMBRIONARIO DE LOS DIENTES}

Los dientes se desarrollan a partir de brotes epiteliales que, normalmente, empiezan a formarse en la porción anterior de los maxilares y luego avanzan en dirección posterior. En el curso de su desarrollo aparecen sucesivamente dos clases de dientes; los dientes primarios (deciduos o de leche) y los permanentes o definitivos. Ambos se originan de la misma manera y presentan una estructura similar.

El ciclo vital de los órganos dentarios comprende una serie de cambios químicos, morfológicos y funcionales que comienzan en la sexta semana de vida intrauterina y continúan a lo largo de toda la vida del diente. La matriz extracelular del diente está formada por dos elementos principales, el esmalte y la dentina, cada uno de ellos procede de diferente epitelio embrionario entre los que se establecen íntimas interacciones durante el desarrollo intrauterino. Son numerosos los mecanismos que guían y controlan el desarrollo dental, pero el esencial, es el fenómeno inductor para el comienzo de la organogénesis dentaria.

Cada diente posé una morfología típica y cada tipo de diente se forma en una localización característica. El patrón de dentición, durante largo tiempo desconocido, gracias entre otros, al trabajo de Kraus y Lufkin (1999), actualmente, vamos conociendo las bases moleculares de dicho patrón, así, los arcos maxilar y mandibular expresan los genes que contienen homeobox Dlx-1 y Dlx-2 y la supresión de estos genes en ratones transgénicos inhibe la formación de los molares en el maxilar pero no en la mandíbula. 
Debemos mencionar que el desarrollo dentario es un proceso continuo al que para un mejor estudio e interpretación dividimos en etapas, pero no es posible establecer distinciones claras entre los estadios de transición, ya que una etapa se transforma paulatinamente en la siguiente. Los términos que se siguen para cada una de estas etapas son meramente descriptivos de la morfología, y no hacen referencia a los profundos cambios funcionales que ocurren en el mismo, es por ello, por lo que se llega a cierta disparidad en su nomenclatura dependiendo de la bibliografía empleada, para unificar criterios y evitar este problema hemos adaptado la terminología de textos clásicos de embriología como (Lagman, Carlson, Larsen, Moor).

El desarrollo embrionario de los dientes comienza en la sexta semana de vida intrauterina, se originan a partir del ectomesénquima del primer arco, procedente de la cresta neural rombencefálica a la altura del rombómero dos y, del ectodermo que recubre este arco. Se forma en el maxilar y en la mandíbula la placoda dental, engrosamiento del epitelio bucal con forma de herradura inducido por las células ectomesenquimatosas en el epitelio de la boca, que proliferará recibiendo el nombre de lámina dental (Figura 1).

A su vez el epitelio de la placoda dental induce la condensación del mesénquima circundante en aquellos puntos en los que se formará un diente temporal, dando lugar a la papila dental de la que derivarán la dentina y la pulpa dentaria. El cemento y el ligamento periodontal también se forman de este mesénquima, pero el origen del esmalte, se forma a partir de una yema ectodérmica local, el órgano del esmalte, que aparece en cada punto en el que ha de formarse un diente, aún no se sabe bien si dependiente de la cresta neural o del ectodermo de la placoda dental. Durante esta fase del desarrollo dentario tienen gran importancia los factores de trascripción msx-1 y msx-2, los factores de crecimiento como BMP-4 (proteína morfogenética ósea, de la familia de los TGF betas), EGF (factor de crecimiento epidérmico), PDGF (factor de crecimiento derivado de las plaquetas) y otros. 
Estos cambios en el primordio de diente nos conducen al estadio o fase de copa o caperuza (Figura 2), la yema dentaria adopta dicha forma por estar unida al epitelio bucal mediante el borde dental, tallo que desaparecerá posteriormente. Entre el epitelio dental externo, que recubre la periferia de la copa, y el interno, que reviste el interior, existe un tejido laxo que recibe el nombre de retículo estrellado, denominándose estrato intermedio al tejido inmediatamente en contacto con el epitelio interno. Al progresar la invaginación del órgano del esmalte podemos hablar de fase de campana (Figuras 3 y 4).

Durante la fase de copa, el epitelio dental interno, inducido por el mesénquima de la papila dental, se diferencia en preameloblastos, futuras células generadoras del esmalte, que a su vez inducen el mesénquima subyacente la diferenciación de preodontoblastos y odontoblastos. En el proceso de maduración de los odontoblastos parecen estar fuertemente implicadas moléculas de la membrana basal situada entre el epitelio dental interno y la papila dental, tales como fibronectina, decorina, tenascina, amelogeninas y esmaltinas, así como factores de crecimiento como TGF-beta1 (factor de crecimiento transformante beta 1) y BMP-2 (proteína morfogenética 2), secretados por los preameloblastos. Los odontoblastos secretarán la predentina, cuya calcificación dará lugar a la dentina en cuyo espesor se encuentran los canales dentinarios ocupados por prolongaciones de los odontoblastos: los procesos odontoblásticos.

El paso de preameloblastos a ameloblastos, que requiere la presencia de dentina producida por los odontoblastos, da lugar a la secreción de proteínas aniónicas especificas en la unión amelodentinaria que actúan como núcleos para la formación de cristales de hidroxiapatita, componente inorgánico dominante del esmalte, cuyo crecimiento y orientación depende de las amelogeninas y las esmaltinas. Cuando entran en la fase de maduración, los ameloblastos segregan proteinasas que reabsorben la matriz orgánica con lo que aumenta el contenido inorgánico del esmalte y son rechazados hacia el epitelio dental externo con el que desaparecerán al poco de erupcionar el diente. 
Al ir madurando el esmalte y formándose la corona, el cuello del órgano del esmalte se alarga alrededor del mesénquima de la papila dentaria como un cilindro constituido por dos capas celulares que continúan el epitelio dental externo e interno: es la vaina epitelial radicular, implicada en el desarrollo de la raíz dental. La capa interna, como el epitelio dental interno, induce la diferenciación de odontoblastos a partir de las células mesenquimatosas contiguas, conformando la raíz e iniciándose la dentinogénesis en esta región, momento en el que el epitelio de la vaina radicular se vuelve fenestrado, permitiendo el contacto de la zona más externa de dentina radicular con el mesénquima en el que se diferenciarán los cementoblastos, formadores de cemento y las fibras de Sharpey del ligamento periodontal, momento en el que los restos de la vaina epitelial radicular desaparecen. El diente se rodea pronto de hueso salvo en su porción coronal, se fija al alveolo dentario por el ligamento periodontal y a partir del sexto mes del nacimiento el crecimiento radicular es suficiente para hacer erupcionar el diente en la cavidad bucal. La secuencia de erupción se inicia con los incisivos centrales, a los pocos meses (6-8) del nacimiento y continúa de forma escalonada hasta que se forma el último molar deciduo al final de los dos años, en total se forman 20 dientes caducos o de leche

El desarrollo de los dientes permanentes tiene lugar de forma similar al de los temporales. Aproximadamente en la decimosexta semana, cuando el diente temporal está en forma de copa, aparece una yema en el borde dental del diente temporal que originará el diente definitivo, situado en el mesénquima lingual al diente temporal, $\mathrm{y}$, conforme va creciendo, los osteoclastos del hueso circundante van reabsorbiendo de forma progresiva la raíz del temporal. Por el contrario, los molares, se forman a partir del borde profundo de un compacto cordón epitelial, que en ningún momento está en contacto con la superficie bucal, producido por el alargamiento en sentido distal de la lámina dental al crecer la mandíbula y en el que se desarrollan en sentido mesiodistal las yemas dentarias de los tres molares permanentes (la del primer molar en la semana decimosexta, la del segundo hacia el año de vida y la del tercero hacia los cinco años). Las yemas se inician en la rama de la mandíbula, pero la reabsorción progresiva del borde 
anterior de la apófisis coronoides hace que ocupen el cuerpo de la mandíbula. La erupción de los dientes permanentes comienza generalmente durante el sexto año de vida, su secuencia es la misma que la de los caducos, pero se forman 12 piezas adicionales que no tenían representación en los dientes caducos, 32 piezas totales. (Enlow y Hans, 1998; Martínez y Linares, 1998; Silio y Arechaga, 1998). 


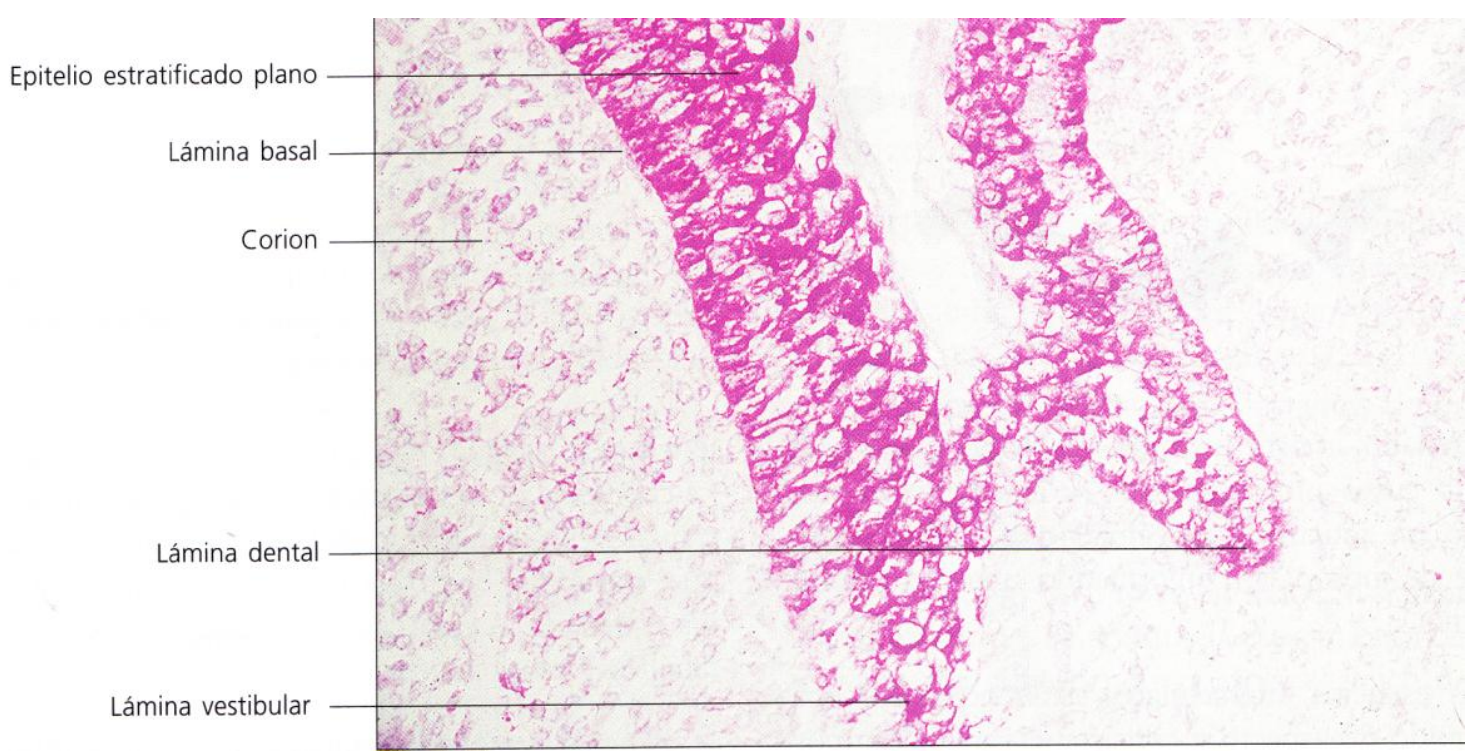

Figura1.- Estadio de yema dentaria en la que se aprecia la diferenciación de lámina dental y lámina vestibular. (Tomado de Gómez y Campos, 2000)

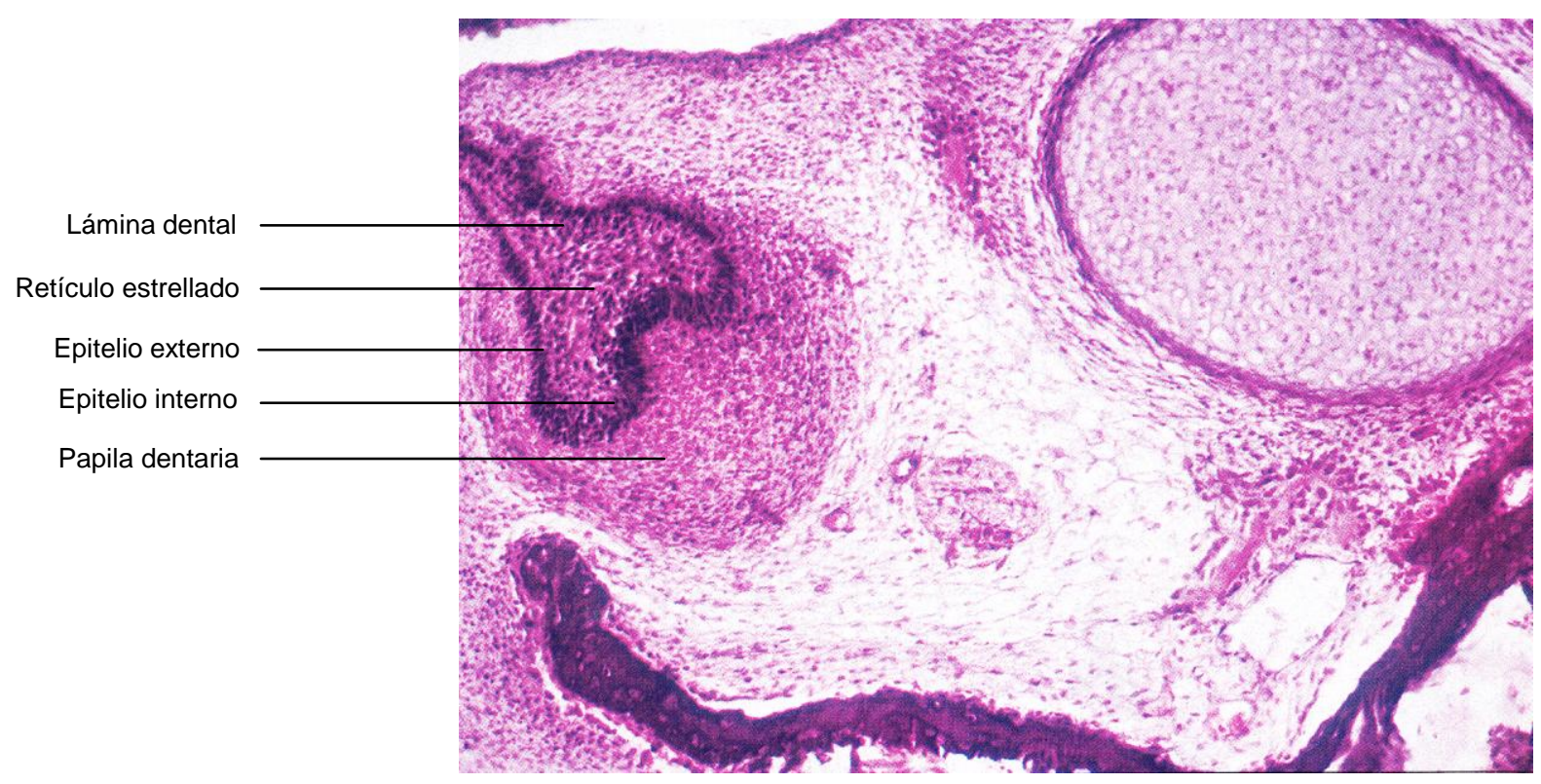

Figura 2.- Estadio de copa o casquete, periodo inicial. (Tomado de Gómez y Campos, 2000) 


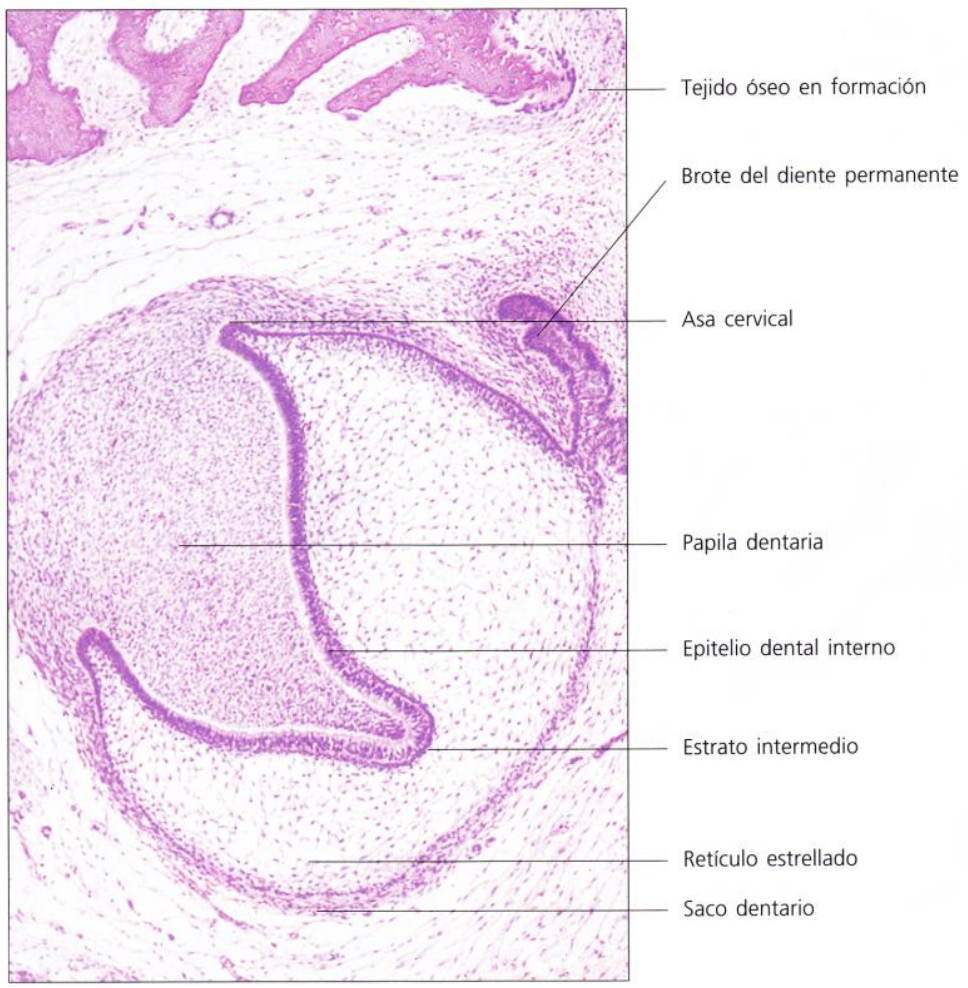

Figura 3.- Fase inicial del estadio de campana. (Tomado de Gómez y Campos, 2000)

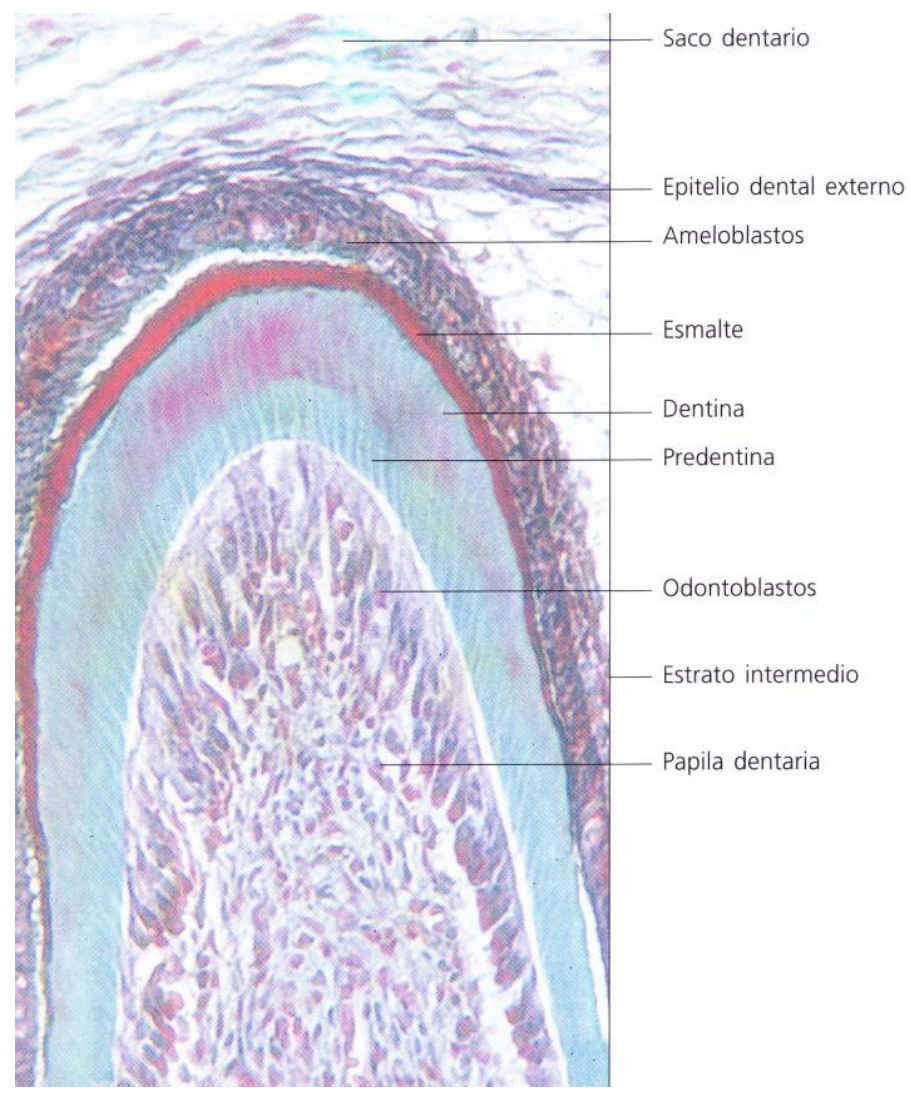

Figura 4.- Fase final del estadio de campana, en el que se detallan los tejidos duros del diente.

(Tomado de Gómez y Campos, 2000) 


\section{2.- IMPORTANCIA DE LA IMAGEN 3D PARA EL DIAGNÓSTICO CLÍNICO Y EL RECONOCIMIENTO DE ESTRUCTURAS ANATÓMICAS}

En los últimos años se han llevado a cabo estudios que permiten automatizar el análisis de imágenes médicas y la reconstrucción tridimensional con gran valor para el diagnóstico clínico y para el desarrollo de sistemas quirúrgicos de navegación (Dumoulin y cols., 2003; Verhey cols., 2006; Rosen y cols., 2014 ).

Los exámenes tomográficos y de resonancia contienen enorme cantidad de información, permitiendo diferenciar diversas estructuras anatómicas. A esta información puramente morfológica, se agregan las variaciones de la normalidad, tanto por aparición de elementos nuevos (por ejemplo, tumores) como por los desplazamientos y cambios en la densidad de los órganos corporales.

Por otro lado, las técnicas de imagen aportan valores numéricos que en la actualidad comienzan a tenerse en cuenta y a comprenderse su significado y aplicación en la práctica clínica. Los avances diagnósticos mediante el empleo de técnicas de imágenes corporales tridimensionales, revolucionaron el ámbito de la radiología convencional. Otra utilización de las imágenes 3D, de gran interés en la práctica clínica, es en el desarrollo de simuladores, y en especial los

quirúrgicos. Hasta hace pocos años, las prácticas que recibían los cirujanos se basaban en el empleo de cadáveres, animales vivos o intervenciones quirúrgicas tuteladas; todo ello conllevaba problemas: éticos, escasez de sujetos y posibilidades intervencionistas mínimas en algunas patologías. Con la llegada de la tecnología informática aplicada a las ciencias de la salud y la generación de modelos anatómicos en 3D surgieron los simuladores quirúrgicos. Entre sus ventajas más notables destaca la reducción en costes en sujetos utilizados, así como el aporte de ámplia experiencia para los cirujanos, posibilidad de simular abundantes tipos de patologías y posibles complicaciones, repetir los ensayos quirúrgicos tantas veces como sea necesario, incluso realizar las operaciones 
virtuales de una forma planificada, en el momento más conveniente para el cirujano.

Los sistemas de simulación quirúrgica están compuestos básicamente por dos subsistemas: el interface de usuario, cuya finalidad es suministrar una visualización de la reconstrucción computarizada de los órganos internos de interés, para lo cual se emplean modelos avanzados de geometría compleja para objetos en visualización 3D y modelos deformables para incorporar propiedades físicas a las estructuras 3D generadas por el ordenador junto con técnicas de visualización avanzadas (Montserrat, 1999; Monserrat y cols., 2000). El segundo subsistema corresponde a los sensores, compuestos por un conjunto de dispositivos "haptic" que pueden imitar a los utensilios empleados por los cirujanos en las situaciones reales de cirugía (Eve y cols., 2014).

En la creación de estos simuladores se han empleado con éxito los cortes de cadáveres procedentes del "Proyecto Visible Human" (VHP), en sus diversas versiones. El primero se planificó en 1986 por la National Library of Medicine en Bethesda (Maryland, USA) y fue desarrollado por la Universidad de Colorado (Denver, USA). Compila datos a partir de RM, TC e imágenes anatómicas de cadáveres de un varón de 39 años y de una mujer de 59 (Spitzer y cols., 1996). En el año 2001, se inició en la Universidad de Ajou (Suwon, Corea) el experimento para obtener el "Visible Korean Human" cuyos datos suplementaron a los del VHP (Chung y cols., 2000; Park y cols., 2005 y 2006). Poco después se desarrolló el proyecto del "Chinese Visible Human" (Zhan y cols., 2003 y 2006) con imágenes anatómicas, de TC y RM de varios cadáveres de varones y mujeres chinos.

Mediante reconstrucción volumétrica, las imágenes de los cortes transversales obtenidos en los diferentes modelos del VHP pueden transformarse en imágenes 3D de estructuras anatómicas, incluidas el cuerpo entero, que constituyen por sí mismas una biblioteca de valor incalculable para la educación en ciencias de la salud y para la investigación (Park y cols., 2006). A partir de las 
secciones de los VHP y debido a que los cortes tienen siempre un grosor constante y a que han sido practicados a distancias constantes, es posible crear un medio que puede ayudar al médico en la planificación pre y post-operatoria.

La cirugía asistida por ordenador es un campo de tecnología desarrollado recientemente que intenta crear y dotar de herramientas a los cirujanos en sus diversas vertientes, para el diagnóstico y la planificación de intervenciones quirúrgicas (Adams y cols., 1990). Se aplica a un número amplio de especialidades médico-quirúrgicas (Taylor y cols., 1996; Lund y cols., 2011) si bien donde se ha encontrado una mayor utilización es en el campo de la neurocirugía ya que es la especialidad que demanda mayor precisión en el abordaje quirúrgico (Widmann, 2007).

La neurocirugía tradicional, la cirugía maxilofacial, la cirugía bucal, etc... implican la utilización de técnicas manuales basadas en la coordinación entre manos y vista del cirujano usando los datos suministrados por técnicas radiográficas proyectivas y signos clínicos deducidos a partir de hallazgos anatómicos que llevaban a largas y tediosas intervenciones con importantes secuelas para los pacientes.

Estas cirugías actualmente están mejorando constantemente sus procedimientos teniendo como base los avances tecnológicos en imagen corporal, lo que ha permitido el desarrollo de técnicas quirúrgicas asistidas por ordenador.

En los procedimientos actuales se comienza con una fase de adquisición de datos que defina la lesión patológica y su relación espacial con las estructuras normales que deban ser preservadas. El siguiente paso, tras el diagnóstico, es la planificación quirúrgica que defina el abordaje más seguro durante la intervención y es aquí donde tiene máximo interés la composición 3D de la anatomía del paciente y de la localización de la lesión. Además, imágenes 3D conseguidas durante la cirugía serían útiles para identificar marcas anatómicas con el fin de mantener la orientación espacial (Park y cols., 2006). 
Los prototipos pioneros en simulaciones quirúrgicas fueron desarrollados sobre colecistectomía laparoscópica, en la universidad de California (Downes y cols., 1997), el simulador laparoscópico, de la universidad de MisssouriColumbia (Basdogan y cols., 1998) y actualmente modificado por Santos y cols., (2011); "Virtual Endoscopy" (Robb, 2000); "Hepatic Surgery Simulator" desarrollado por Cotin y cols., (1996) en Francia; "anastomosis Simulator" desarrollado por Boston Dynamics Inc. o el "Arthroscopic Knee Surgery Simulator" desarrollado por Gibson y cols., (1997).

En España, existe una línea de investigación sobre el tema desde hace años y se han desarrollado varios simuladores en la Universidad Politécnica de Valencia para el entrenamiento en cirugía avanzada (Montserrat y cols., 2000).

Además de las potenciales aplicaciones de las imágenes 3D generadas a partir de los cortes del "Human Visible" en el campo de la cirugía virtual y de la endoscopia virtual, existen también aplicaciones para la resucitación cardiopulmonar virtual.

Las interpretaciones endoscópicas o broncoscópicas virtuales, con color real, podrían ser de gran utilidad en el entrenamiento y preparación del personal sanitario.

También puede diseñarse un programa virtual sobre resucitación cardiopulmonar, basado en imágenes creadas a partir de imágenes anatómicas segmentadas de tórax. Un maniquí con sensores de presión y utensilios "haptic" podría unirse a las imágenes 3D de la pared torácica, corazón y pulmones, generadas en el ordenador y podrían ir transformándose en tiempo real, a medida que se manipula el maniquí. Cada actuación virtual podría ser valorada y puntuada en relación con un patrón previamente diseñado (Park y cols., 2006). 


\section{3.- PAPEL DE LAS TÉCNICAS DE IMAGEN DIAGNÓSTICA PARA EL RECONOCIMIENTO DE ESTRUCTURAS DEL APARATO DENTARIO}

Las técnicas de diagnóstico radiológico aportan información anatómica y posibilitan la detección de procesos patológicos por lo que son un adecuado complemento no invasivo del diagnóstico clínico.

\section{Radiografía intraoral}

Abarca todas aquellas técnicas en las que la película radiográfica se coloca dentro de la cavidad oral. Por su sencillez, es el procedimiento de examen radiográfico más utilizado en Odontología.

Se pueden diferenciar tres tipos de técnicas: periapical, oclusal y de aleta de mordida.

Técnica periapical o retroalveolar

De utilidad en la valoración detallada del diente y del proceso alveolar, de un sector determinado del maxilar superior o inferior, y como orientación de la clase de trabeculación ósea.

\section{$\underline{\text { Técnica de la bisectriz }}$}

La más clásica y frecuente en la práctica odontológica. El rayo central incide perpendicularmente a la bisectriz formada por el eje dentario y el eje de la película pasando a través del ápice dentario.

Tiene el inconveniente de que produce una deformación geométrica del objeto radiografiado.

$\underline{\text { Técnica de paralelismo }}$

Por su buena definición, es de elección en los casos de valoración periodontal o implantológica del paciente (durante el acto quirúrgico o como 
comprobación de la osteointegración), permitiendo una valoración orientativa de la calidad ósea y resaltando la localización exacta de determinadas estructuras anatómicas tales como las fosas nasales, los senos paranasales y los conductos dentarios.

También es muy útil a la hora de valorar el espacio mesiodistal disponible en un sector concreto, o entre un diente y una estructura anatómica como el seno maxilar o el agujero mentoniano, pero si no se realiza de forma correcta, puede dar lugar a errores en la medida de la anchura observada por la distorsión que se produce debido a las diversas formas anatómicas y a la dificultad de colocación de la película, con la limitación añadida del pequeño campo observado.

En la actualidad hay en el mercado diferentes sistemas de radiología intraoral digital que, manteniendo una buena resolución, disminuyen la dosis que recibe el paciente e incorporan diferentes programas de tratamiento de imágenes con posibilidades de medida de densidades, etc.

\section{Técnica oclusal}

Nos proporciona una imagen completa del maxilar superior o de la mandíbula con escasa magnificación dado que la película se sitúa en contacto con los dientes o con el reborde alveolar.

Sirve para evaluar la anchura mandibular y la posición, en sentido vestíbulo-lingual, del conducto dentario inferior, pero debido a la superposición de todo el espesor mandibular, no es demasiado fiable, siendo por el contrario de gran utilidad en la comprobación de perforaciones de la cortical durante la colocación de implantes.

\section{Técnica de aleta de mordida}

Recibe este nombre porque la película está alojada en un paquete que tiene una "aleta" que debe ser mordida por el paciente. 
Podemos visualizar el reborde óseo marginal y las coronas de los dientes tanto superiores como inferiores, por lo que sus indicaciones principales son la localización de caries interproximales, detección de obturaciones desbordantes, determinación del ajuste de prótesis fijas, descubrimiento de depósitos de sarro, etc. (Carranza, 1990; Verdasco y cols., 1994; Hernandez, 1998; Macorra, 1998; Clark y Curzon, 2004; Goga y cols., 2004; Khan y cols., 2004; Emmott, 2005; Erten y cols., 2005).

\section{Técnicas radiográficas extraorales}

Se pueden clasificar, en función del plano de referencia observado, en:

\section{Frontales}

Pueden ser anteroposteriores o posteroanteriores, siendo más útiles estas últimas al ofrecer una mejor definición del macizo facial. Igualmente pueden llevarse a cabo de forma unilateral o bilateral, en cuyo caso se puede realizar una comparación entre ambos lados.

Podemos diferenciar dos métodos diferentes:

- Técnicas fronto-naso

- Técnicas naso-mento, destacando entre éstas la proyección descrita por Waters en 1915 para el estudio de los senos paranasales (principalmente maxilares).

Laterales

Podemos dividirlas en dos grupos:

- Radiografías laterales estrictas: Telerradiografía lateral de cráneo con cefalostato:

Técnica muy estandarizada y por lo tanto fácilmente reproducible en la misma posición, lo que la convierte en una proyección ideal para realizar mediciones, 
siendo utilizada habitualmente en ortodoncia y en algunas aplicaciones en implantología. Con ella podemos valorar los sectores anteriores y observar la relación ósea maxilomandibular y su correspondencia con el perfil blando.

- Variantes (actualmente desplazadas por la radiografía panorámica):

Localizadas en los huesos propios de la nariz.

Para la visualización de la articulación temporomandibular.

Técnicas laterales desenfiladas para observar la mandíbula.

\section{Axiales}

Son utilizadas para la observación axial del cráneo, y pueden también dividirse en:

- Proyección clásica descrita por Hirtz que permite observar la angulación de los cóndilos articulares en relación con la línea media del cráneo (actualmente sustituida por la tomografía computarizada).

- Variantes:

> Técnica para visualizar la pirámide nasal.

Técnica para observar los arcos cigomáticos.

(Pasler, 1992; Goaz y White, 1995; Martinez, 1998; Ortega, 1998; Gijbels y cols., 2004).

\section{Radiografías con contraste}

La utilización de medios de contraste permite visualizar estructuras que normalmente no podrían observarse en las radiografías. El medio de contraste puede absorber la radiación en mayor (contraste positivo) o menor (negativo) proporción que los tejidos corporales circundantes. Se emplean para visualizar 
los vasos sanguíneos, las glándulas salivales y las articulaciones temporomandibulares.

\section{Angiografía}

Técnica invasiva y por tanto de segunda elección que está indicada principalmente:

- En el estudio de malformaciones del sistema vascular en la región máxilofacial.

- En el diagnóstico diferencial de masas pulsátiles.

- Para definir las relaciones con los vasos y el grado de vascularización de los tumores malignos.

- Para visualizar de forma detallada y de conjunto la anatomía vascular de la zona objeto de estudio (Abu-Serriah y cols., 2004). La angiografía por sustracción digital, en la que se realiza un proceso de sustracción computarizada a partir de la imagen simple y la imagen con contraste, permite obtener una buena información de la vascularización arterial de la zona con un menor volumen de contraste.

\section{Sialografía}

Permite, mediante la introducción retrógrada de un contraste a través del sistema excretor, la visualización de las glándulas salivales. El medio de contraste es introducido mediante un catéter de plástico. En la actualidad, se utilizan contrastes hidrosolubles.

Contraindicada en los casos de lesión o inflamación aguda, es de utilidad en el diagnóstico de las enfermedades de las glándulas salivales, permitiendo el estudio del sistema excretor y del parénquima glandular:

- Enfermedades litiásicas (permite la detección de cálculos radiolúcidos). 
- Sialoadenitis de tipo glandular (dilatación de los acinos glandulares sin afectación del sistema conductor) o ductal (dilataciones nodulares del sistema excretor sin visualización de las ramificaciones finas ni de los acinos).

- Tumores mayores de $5 \mathrm{~mm}$ : posición, tamaño, extensión y signos de infiltración (rotura de conductos, extravasación del contraste, defectos parenquimatosos y contornos borrosos).

- Delimitación de enfermedades periglandulares.

Cuando la utilización de técnicas de estratificación (que permiten detectar masas pequeñas), la sialografía fraccionada (para el estudio del flujo de saliva) o la sialografía por sustracción (mejor imagen del contraste) no son suficientes, emplearemos la tomografía computarizada y la resonancia magnética, en especial cuando se trate de valorar el crecimiento en profundidad de los tumores. (Martin-Granizo y Garcia-Gonzalez, 2004; Morimoto y cols., 2005).

\section{Técnicas radiológicas de estratificación}

\section{Radiografía panorámica}

Pese a sus deficiencias y a la necesidad de realizar radiografías complementarias, la radiografía panorámica u ortopantomografía ha demostrado su utilidad como medio diagnóstico. La radiografía panorámica proporciona una representación radiológica de conjunto de todo el aparato masticatorio, del maxilar superior, de la mandíbula, de las articulaciones temporomandibulares y de la región mediofacial, resultando de gran utilidad como método inicial de detección para:

- La visualización de los huesos maxilares.

- La detección de alteraciones en los senos maxilares.

- El estudio ortodóncico del paciente. 
- El diagnóstico de fracturas.

(Aguirre y Caballero, 1995; Alandez y cols., 1996; Acero y Somacarrera, 1998; Lucas y cols., 1998; Lee y cols.[2], 2004; Legovic y cols., 2004; Molander y cols., 2004; Alhaija, 2005; Sedaghatfar y cols. 2005).

Ecografía

La aplicación de los ultrasonidos en el diagnóstico se basa en la detección y representación de la energía acústica reflejada en las distintas interfases corporales, es decir, en las superficies que separan medios de impedancia acústica distinta.

En el campo del diagnóstico se emplean frecuencias de entre 2 y 12 $\mathrm{MHz}$.

La ecografía:

- Constituye un método eficaz para el diagnóstico de las lesiones ocupantes de espacio (clasificándolas ecográficamente en sólidas, quísticas o complejas).

- Posibilita la libre elección del plano de corte y el estudio de los movimientos en tiempo real.

- Permite controlar y dirigir la PAAF (punción-aspiración con aguja fina).

- Es biológicamente inocua y de escaso coste económico.

En la zona de cabeza y cuello se emplea sobre todo para el estudio de los órganos parenquimatosos y tumoraciones de partes blandas de estas regiones:

- Ganglios linfáticos: es la técnica más sensible para la valoración (no etiológica) de los ganglios cervicales, posibilita calcular su volumen, permite estudiar la infiltración de paredes vasculares, no precisa la aplicación de 
medios de contraste y, en el control de recidivas, permite distinguir entre el tejido cicatrizal (ecodenso) de las recidivas (ecolúcidas).

- Tumores de la cavidad oral y de la orofaringe, fundamentalmente tumores malignos del suelo de la boca y de la lengua: permitiendo determinar con exactitud tamaño, longitud, relación con la línea media, afectación de la pared faríngea lateral y, al igual que en el caso de los linfáticos, distinguir entre recidivas y cicatrices (aunque no se puede diferenciar una recidiva de otras alteraciones ecolúcidas: inflamación, absceso...). También presenta gran sensibilidad para la detección de infiltraciones óseas y reacciones periósticas.

- Procesos parenquimatosos de las glándulas salivales, especialmente de la parótida, debido a su localización superficial: en la litiasis salival detecta cálculos no radiopacos, la morfología ecográfica varía en función del tipo histológico del tumor, poseyendo un mayor valor diagnóstico en los casos de ademoma pleomorfo, cistoadenolinfoma o carcinoma, y también permite distinguir entre alteraciones cicatriciales y recidivas tumorales.

- Infiltrados inflamatorios y abscesos: permite su diferenciación, localización y control, proporcionando información muy útil para su drenaje.

- Senos paranasales.

- Tejidos blandos de la órbita.

- Quistes cervicales.

- Hemangiomas.

- Tejidos blandos de la cara y diagnóstico intraútero de las fisuras labioalveolopalatinas.

- Estudio ecográfico de las articulaciones temporomandibulares, del reborde alveolar, del ligamento periodontal y, con la ayuda de la ecografía Doppler, del estado de la vascularización de una zona determinada. 
(Bernstein, 1978; Bernstein, 1990; Van holsbeeck e Introcaso, 2002; Windisch y cols., 2004; Shimizu y cols., 2005).

\section{Tomografía convencional}

Está basada en la visualización radiológica detallada de los órganos en un plano corporal correspondiente al plano de rotación de un sistema móvil constituido por el tubo de rayos $\mathrm{X}$ y el sistema receptor.

La ventaja de las imágenes tomográficas es la posibilidad de visualizar estructuras determinadas evitando superposiciones. Por el contrario, tienen como inconveniente una pérdida de contraste y de precisión, sobretodo cuando se trata con estratos muy finos.

La visualización tomográfica del esqueleto máxilofacial supera a las imágenes convencionales principalmente en las siguientes situaciones:

- Determinación de la relación espacial de los dientes incluidos con el nervio dentario inferior.

- Localización de cuerpos extraños.

- Valoración de la extensión de lesiones quísticas o tumorales.

- Diagnóstico de fracturas, especialmente del suelo de la órbita.

- Estudio de las formaciones quísticas de los senos maxilares.

- Determinación de la extensión de la osteomielitis mandibular.

- Enfermedades que afectan a la articulación temporomandibular.

\section{Tomografía computarizada}

Es una técnica radiológica especial en la que solamente se visualiza la información relativa al corte objeto del estudio. La detallada imagen obtenida matemáticamente a partir de los datos medidos está libre de superposiciones 
(imagen de sustitución). Las imágenes de cortes transversales (axiales) del cuerpo humano tienen la ventaja de que, con los programas informáticos adecuados, pueden obtenerse imágenes secundarias (imágenes multiplano) de corte sagital, coronal, paraaxial o incluso oblícuos. Se han desarrollado equipos diseñados específicamente para el estudio maxilomandibular que utilizan un haz cónico en lugar del tradicional haz en abanico, por lo que la técnica recibe el nombre de tomografía computarizada de haz cónico (CBCT).

La TC permite la visualización de las partes blandas, pudiéndose determinar la densidad y el grado de vascularización de algunos procesos expansivos mediante la inyección de un contraste intravenoso. Por tanto su principal ventaja es la visualización simultánea de huesos y partes blandas con gran definición de densidades.

Sus principales aplicaciones en la región bucomaxilofacial son:

- Visualización de procesos tumorales de zonas poco accesibles para la radiología convencional (fosa pterigopalatina, infratemporal, región parafaríngea, senos paranasales, órbita, base del cráneo, contenido craneal...).

- Detección de ganglios linfáticos aumentados de tamaño.

- Valoración de inflamaciones, tumores (con medio de contraste) y calcificaciones de las glándulas salivales. En el caso concreto de la parótida, proporciona información sobre la relación del nervio facial con el tumor y, combinada con la sialografía, permite localizar topográficamente los tumores intraglandulares.

- Evaluación rápida y global de las lesiones craneofaciales, permitiendo un diagnóstico preciso de la fractura y proporcionando el grado de afectación de las partes blandas.

- Visualización clara de modificaciones en la forma o defectos de las estructuras óseas de las articulaciones temporomandibulares como las que 
ocurren en la hiperplasia condilar y la poliartritis, aunque no se observa bien el disco articular.

- Diagnóstico general de las alteraciones morfológicas y estructurales de toda la zona craneal y, mediante el empleo de programas de reproducción tridimensional de contornos, la obtención de imágenes tridimensionales.

Un inconveniente relativamente frecuente es la presencia de cuerpos metálicos, materiales de osteosíntesis y prótesis dentales, que pueden generar artefactos que deterioran sensiblemente las imágenes.

(Joseph y Spital, 1978; Glover y Eisner, 1979; Glover y Pelc, 1980; Joseph, 1981; Pasquet y Cavezian, 1993; Yanagisawa y cols., 1993; Muñoz y cols., 1998; Rothman, 1998; Alberico y cols., 2000; Cova y cols., 2003; Donado y cols., 2003; Kim y cols., 2003; Scribano y cols., 2003; Varvara y cols., 2003; Baba y cols., 2004; Mupparapu y Singer, 2004; Nkenke y cols., 2004; Podesser y cols., 2004; Katsumata y cols., 2005; Rachmiel y cols., 2005).

\section{DentaScan.}

La creciente necesidad de una mayor precisión en el diagnostico y tratamiento de los problemas odontoestomatológicos, ha exigido a los profesionales de esta especialidad un mejor conocimiento de la anatomía para la mejor interpretación de los estudios exploratorios que el desarrollo tecnológico pone a su alcance.

Si bien, durante largo tiempo la radiología simple ha sido de gran ayuda para el médico estomatólogo. Fue la aplicación de los estudios mediante Tomografía convencional (TC) en el campo de la odontología por Hounsfield (1973), la que dio un gran impulso para el manejo clínico de la alteraciones dentales y patología oral. A partir de esta fecha se han desarrollado varias generaciones de $\mathrm{TC}$, hasta que a finales de los años noventa aparece la Tomografía Digital Volumétrica o tomografía de haz cónico (CBCT) con el 
objeto de obtener scaneres tridimensionales del esqueleto máxilofacial con una menor dosis de radiación (Arai y cols., 1999; Mozzo y cols., 1999). Ello ha ofrecido una alternativa a la imagen convencional intraoral y panorámica que elude la superposición y la distorsión de imágenes para planificar una mejor pauta de tratamiento.

Sin embargo, aunque hay autores entre ellos Hanazawa y cols. (2004) y Oviedo-Muñoz y Hernández-Añaños (2012), quienes señalan esta técnica como ideal para la planificación implantológica e incluso para el resto de patologías bucales, aún persisten ciertas discrepancias respecto a su uso rutinario en la implantología dental por el efecto adverso que supone la radiación recibida por el paciente (Arana Fernández de Moya y cols. 2006).

Otra explicación que limitaría su utilización sistemática es la recomendación de la Academia Americana de Radiología Oral y Maxilofacial quien recomienda que la obtención e interpretación de imágenes no sea realizada sin el adecuado entrenamiento y que antes de la reparación e implante, el clínico busque el citado entrenamiento u obtenga la necesaria información radiográfica del radiólogo (Tyndall y Brooks, 2000).

Independientemente de los pros y contras, la evolución de la imagen convencional a imágenes 2D y 3D otorga enormes beneficios al clínico y al paciente, a este último, por el menor tiempo de exposición a la radiación comparando la tomografía convencional y la de haz cónico (Gamba y cols., 2007). Al clínico, porque el tomógrafo de haz cónico representa el desarrollo tecnológico de un equipo relativamente pequeño y de menor costo, dedicado especialmente a la región dentomaxilofacial, lo que permite realizar exploraciones dinámicas de las imágenes adquiridas, incluso la reproducción de la imagen tridimensional de tejidos maxilofaciales mineralizados con mínima distorsión y dosis de radiación significativamente reducida con relación a la tomografía convencional. 
Dentro de los campos de aplicación de la tomografía de haz cónico, el conocimiento de la anatomía radicular se ha enriquecido enormemente, con la aplicación de esta técnica se ha demostrado la enorme variabilidad y complejidad de los conductos radiculares, conductos accesorios y múltiples forámenes (Kau y Richmond, 2005).

Por ello, muchos profesionales consideraron que pudiera ser una técnica ideal de uso rutinario previo al tratamiento endodóntico, sin embargo, (Estévez y cols., 2009) consideran que la tomografía volumétrica permite realizar reconstrucciones en $3 \mathrm{D}$ de una manera no invasiva y reproducible del sistema de conductos, siendo una herramienta muy útil para el entrenamiento preclínico, y un mejor entendimiento del sistema de conductos, pero que no se debe emplear para uso clínico, por su alta radiación y el elevado coste que supone.

Son varios los autores, (Kottoo y cols., 2010; La y cols., 2010) entre otros, quienes han utilizado la tomografía de haz cónico en una amplia muestra de pacientes, algunos con tratamiento anterior, observaron gran cantidad de variantes de conductos radiculares, contabilizando casos de hasta cinco conductos en una misma raíz, no observables con otras técnicas diagnósticas, considerándola como técnica ideal en aquellos casos con tratamiento previo de conducto y persistencia de sintomatología.

Adicionalmente, (Hassan y cols., 2009) y más tarde (Hassan , 2010) en pacientes con fracasos del tratamiento de obturación radicular sin apreciación de datos relevantes tras radiografía periapical, la realización de scanner CBCT demostró que la mayoría de los pacientes presentaban fracturas radiculares longitudinales, desapercibidas mediante la radiografía convencional, considerándola por tanto, como la técnica de elección para el diagnóstico, pronóstico, plan de tratamiento para el manejo de estos casos (Tetradis y cols., 2010). En los mismos, también se pueden reconocer reabsorciones radiculares 
perforaciones y comunicación con el espacio del ligamento periodontal (Cotton y cols., 2007).

Teniendo en cuenta que el principal objetivo del tratamiento endodóntico es la preparación mecánica y limpieza química de todo el sistema de conductos radiculares y dentina contaminada, seguida de una adecuada obturación. Con demasiada frecuencia durante el trabajo clínico únicamente nos basamos en conceptos teóricos sobre la anatomía dental pero no tomamos en cuenta las variaciones anatómicas que se pueden presentar, lo cual podría conllevar al fracaso del tratamiento, es por ello, por lo que un diagnóstico adecuado previo, nos conducirá a un adecuado plan de tratamiento que aumentará el prestigio del profesional y la satisfacción del paciente (Patel y cols., 2009), a ello, contribuye en gran medida el scaner CBTC.

Sin embargo, actualmente donde más extendida está su utilización de forma rutinaria es en el campo de la implantología, donde se pueden analizar las dimensiones de hueso, la calidad y la altura del hueso alveolar (Monsour y Dudhia, 2008).

Para Guerrero y cols. (2006), el estudio previo con scaner de haz cónico en 3D optimizará el plan de tratamiento con implantes dentales en los siguientes puntos: Para localizar y determinar la distancia a las estructuras anatómicas vitales. Medir la anchura del hueso alveolar y visualizar el contorno del hueso. Determinar si es necesario un injerto de hueso o un levantamiento de seno. Seleccionar el tamaño y el modelo de implante más adecuado. Optimizar la localización del implante y su angulación. Reducir los tiempos quirúrgicos.

Otra de su recomendación es en la ortodoncia, permite obtener un diagnóstico ortodóntico más comprensible y un plan de tratamiento más preciso ya que permite realizar un análisis cefalométrico en tres dimensiones (Lamichane y cols., 2009; Lenguas y cols., 2010). 
Los avances en la imagen han evolucionado el tratamiento de las deformidades dentofaciales y el campo de la cirugía ortognática, la utilización de la tecnología de la fusión de la imagen permite crear una reconstrucción ana tómica real de ese paciente, con un registro preciso de todas las imágenes tridimensionales superpuestas en una estructura anatómica tridimensional válida (Schendel y Lane 2009).

\section{Resonancia magnética}

Esta técnica se basa en la interacción de campos magnéticos y ondas de radiofrecuencia con la materia. En la región oromaxilofacial, permite visualizar los músculos, las amígdalas, las mucosas, los ganglios linfáticos y los vasos mejor que con la tomografía computarizada. Sin embargo, la visualización de la cortical ósea y de los dientes es deficiente por su alto contenido en calcio y pobre contenido protónico, por lo que es muy difícil detectar los procesos destructivos localizados en el interior de la cortical.

Debe tenerse en cuenta que en las personas con marcapasos, implantes metálicos o clips quirúrgicos ferromagnéticos están contraindicadas las exploraciones por resonancia magnética.

Sus aplicaciones en dicha región son amplias:

- Tumores: consigue una buena visualización en regiones anatómicamente complicadas, proporcionando mayor seguridad que la ecografía y la TC cuando se trata de determinar el estadio de desarrollo del tumor, siendo el método de elección para la detección de alteraciones tumorales de la lengua y de la orofaringe. También permite detectar alteraciones mucosas, siempre que presenten cierta extensión superficial, y alteraciones tumorales de la órbita, permitiendo una detección precoz de su extensión intracraneal. 
- Glándulas salivales: permite visualizar directamente el nervio facial, distinguir entre lesiones quísticas, tumorales e inflamatorias y evidenciar el grado de penetración retromandibular y retromaxilar.

- Senos paranasales: para detectar modificaciones localizadas en su mucosa, principalmente en enfermedades inflamatorias extensas.

- Ganglios linfáticos: en estos casos presenta la ventaja de obtener en una misma toma la localización y sus relaciones topográficas.

- Quistes cervicales: tamaño, extensión y relación con los grandes vasos.

- Angiomas: proporcionando valiosa información complementaria.

- Articulación temporomandibular: proporciona una imagen directa de sus partes blandas, siendo el único método que permite la visualización directa del disco articular determinando su forma, posición dentro de la ATM e incluso detectar perforaciones del mismo.

(Juanes y cols., 1996; Hirschmann, 1998; Sato y cols., 2002; Okano y cols., 2003; Chirani y cols., 2004; Imamura y cols., 2004; Kitai y cols., 2004). 


\section{4.- LA INFORMÁTICA EN LAS CIENCIAS DE LA SALUD: PROGRAMAS DOCENTES INFORMATIZADOS}

El desarrollo de aplicaciones informáticas avanzadas para el estudio de distintos aspectos anatómicos corporales, se está introduciendo cada vez con más fuerza en el terreno médico (Gutierrez, 1997), generándose programas muy valiosos para el estudio anatomo-radiológico como el que presentamos en esta Tesis Doctoral.

La tecnología informática ofrece enormes beneficios a las actividades docentes y de entrenamiento profesional, porque permite descentralizar y acceder a las principales bases de datos, recopilar y poner al día los conocimientos y evaluar de forma multidisciplinar los problemas que se suscitan a diario en la docencia, investigación y práctica clínica.

El extraordinario desarrollo de las nuevas tecnologías ha provocado enormes cambios en la formación en ciencias de la salud. Estos cambios conciernen a varios aspectos de la relación profesor/alumno e implica nuevas tácticas para la enseñanza teórica y práctica y para la preparación de materiales auxiliares (DraKe, 1998; Paalman, 2000; Miller y cols., 2002; Pereira y cols., 2003).

Muchas iniciativas docentes unen nuevas necesidades en el conocimiento anatómico con las cualidades emergentes ofrecidas por los ordenadores (Carmichael y cols., 2000; Trelease y cols., 2000; Hallgren y cols., 2002) manteniendo resultados prometedores (Reidenberg, 2002).

Los desarrollos informáticos 3D, muchos de los cuales tienen como base los cortes anatómicos procedentes de los cadáveres del Proyecto Visible Human $(\mathrm{PVH})$ en sus diversos orígenes (americano, coreano y chino) han revolucionado los paradigmas del aprendizaje anatómico, ya sea por sí mismos o cuando las imágenes 3D se implementan con materiales multimedia y otras fuentes de realidad virtual (Hoffman y Murray, 1999). 
Existen múltiples y variados desarrollos informáticos 3D dirigidos al aprendizaje y mejora de la docencia de la Anatomía, muchos de ellos presentados en CD-Rom's o DVD's, otros localizados en la red y presentados en múltiples "websites".

Los programas multimedia 3D permiten al estudiante y al personal clínico en formación un alto grado de independencia a la hora de programar su formación y la posibilidad de instruirse a distancia a través de Internet accediendo a programas y desarrollos informáticos de universidades repartidas por todo el mundo.

Entre las primeras aplicaciones a los PVH se encuentra la reconstrucción de modelos anatómicos 3D (Kerr y cols., 1996). Este tipo de reconstrucciones 3D son de gran utilidad en la formación docente en ciencias de la salud y en la aplicabilidad al diagnóstico y seguimiento terapéutico de las enfermedades.

La técnica de la renderización permite la creación de modelos 3D donde las texturas asignadas a cada objeto pueden ser colores sólidos, lo que resulta útil para identificar y separar estructuras anatómicas. Una vez renderizadas las imágenes se procede a su reconstrucción volumétrica o "visualización 3D” en la que los colores o texturas asignados a los objetos se obtienen directamente de los valores de cada uno de los vóxels que forman el objeto 3D. Con esta técnica se obtienen reconstrucciones muy realistas y ofrece la posibilidad de ver estructuras situadas en el interior de un corte determinado, a diferencia de la situación en la renderización, donde sólo se consigue la superficie del objeto estudiado.

Un hecho añadido supone la posibilidad de integrar los distintos procedimientos de reconstrucción con lo que se refuerza el objetivo del aprendizaje. En este sentido, es posible obtener una estructura 3D fotorrealista y, sobre ella, asignar un color ficticio a un objeto, como por ejemplo una arteria, que destacaría sobre el resto de la estructura 3D (Juanes y cols., 2003). 
Los desarrollos informáticos 3D deben ser interactivos con el usuario, permitiéndole variar las escenas visuales obtenidas, con rotaciones, cortes, superposición o eliminación de capas, órganos o estructuras, lo que facilita la comprensión de la morfología y relación espacial que mantienen entre sí los diversos objetos que integran la imagen.

A través de imágenes estereoscópicas mezcladas con imágenes de disección junto con narración digital se consiguen programas multimedia interactivos con gran potencial docente (Trelease, 1998). Un ejemplo actualizado de desarrollo informático 3D es el realizado mediante métodos de reconstrucción estereoscópica 3D a partir de imágenes de CT y de RM archivadas en formato DICOM, con el fin de obtener patrones morfológicos y de comportamiento de estructuras vasculares cerebrales que puedan aplicarse al diagnóstico y evaluación terapéutica de aneurismas y otras alteraciones vasculares endocraneales (Zurada y cols., 2008).

Otro programa de desarrollo informático 3D con gran impacto entre los anatomistas y con gran potencial didáctico para la enseñanza y aplicabilidad de la neuroanatomía es el denominado Voxel-Man, el cual es fruto de un proyecto de investigación cuyo objetivo era representar la morfología y la función del cuerpo humano mediante técnicas basadas en la utilización de ordenadores (Schubert y cols., 1997; Pflesser y cols., 2001). El Voxel-Man/Brain es un modelo obtenido a partir de cortes de RM tomados con una resolución espacial de $1 \mathrm{~mm}$; incluye además imágenes de la colección del PVH. En el modelo Voxel-Man/skull se utilizaron imágenes de TC obtenidas con una resolución espacial de $1 \mathrm{~mm}$. El proyecto Voxel-Man, desarrollado en 1998, por el Institute of Mathematics and Computer Science in Medicine (IMDM) (Universidad de Hamburgo, Alemania), está basado sobre un modelo de cuerpo virtual que permite realizar múltiples y diferentes tipos de exploración lo que le convierte en una excelente herramienta para la enseñanza de la anatomía humana y de la anatomía radiológica. 
Un nuevo intento para mejorar los desarrollos informáticos 3D y su aplicación a la docencia de la medicina consistente en tratar de unificar los sistemas de anatomía virtual 3D (basados en sitios Web, incluyendo VH databases e interfaces de navegación), con utensilio "haptic" que permiten añadir el tacto a las estructuras geométricas generadas (Temkin y cols., 2002).

Los programas docentes informatizados no se han estancado en los últimos años; por el contrario, el desarrollo tecnológico aplicado a los grandes aparatos para el diagnóstico de la imagen (por ejemplo, el TC helicoidal multicorte que utilizaremos ampliamente en nuestro trabajo de Tesis Doctoral) junto al gran desarrollo tanto del software como de las técnicas infográficas, están consiguiendo nuevos y depurados desarrollos informáticos al servicio de las ciencias de la salud, en sus diversos campos, que irán modificando los sistemas de enseñanza, como ya se está haciendo en los países con las tecnologías más avanzadas. En este aspecto, es donde se enmarca nuestro trabajo de Tesis Doctoral. 


\section{PLANTEAMIENTO DEL TRABAJO}


En el año 2006, Ackerman y cols., afirmaron que "El arte del pasado se combina con la tecnología del presente para proporcionar una nueva vía de estudio y comprender la complejidad total de la Anatomía Humana en el futuro".

El modo de observar, interpretar, enseñar, aprender Anatomía, hacerla más aplicativa, que sirva para resolver problemas, que ayude al diagnóstico y tratamiento de enfermedades, ha sido una constante desde que empezó a enseñarse Anatomía Humana en todos los centros universitarios del mundo entero.

Desde antiguo y hasta ahora, se ha ido modificando la forma y el modo de interpretar las diferentes estructuras del cuerpo humano. Así, antes del Renacimiento el conocimiento de Anatomía era empírico, basado en la lectura de textos, conociéndose las estructuras, gracias a las disecciones efectuadas en animales y trascritas a los libros sin ilustraciones; las más utilizadas eran las de Galeno y en España la anatomía de los textos árabes (Vázquez y cols., 2007). A partir del Renacimiento y hasta el siglo XVIII, es decir, durante unos doscientos años y para que fueran aprendiendo los futuros galenos, se empezaron a utilizar verdaderas ilustraciones anatómicas, realizadas por artistas, teniendo una base anatómica obtenida de la disección del cadáver; basta ver las ilustraciones de Vesalio, de Albinus o de Valverde de Amusco, por citar algunos de los más conocidos (ver citas en Vázquez y cols., 2007).

Ya bien entrado el siglo XIX, concretamente a partir de su segunda mitad, aparecen los primeros atlas anatómicos, basados en fotografías obtenidas de cadáveres diseccionados, por lo que los conocimientos de la estructura del cuerpo humano fueron más exactos; entre ellos debemos citar el de Gray (1858, tomado de Platzer, 1995), que fue perfeccionándose ya entrado el siglo XX, cuando se 
llegó a combinar datos obtenidos de fotografías con los realizados por artistas, lo cual dio lugar a imágenes reales en cuanto a las relaciones de estructuras se refiere, pero se las retocaba y se dejaba a un lado aquello que no era fundamental para la comprensión de la propia imagen; ejemplo de ello es el atlas anatómico de Grant que apareció en 1943 en dos volúmenes.

Junto con estos atlas, y en la segunda mitad del siglo XIX, aparecen representaciones con láminas sobrepuestas, abriéndose como las hojas de un libro (Witkoswski, 1890) en los que las relaciones entre las estructuras se podían analizar mucho mejor, así como la visión e identificación de los elementos anatómicos.

Un salto importante en los conocimientos anatómicos se produjo con las imágenes radiológicas. En 1896, Roentgen descubrió los R ayos X y obtuvo así la primera fotografía radiológica. Con esta técnica se logró visualizar el cuerpo humano y se pudieron apreciar diferentes estructuras en el individuo vivo, sin tener que abrir el cuerpo; sin embargo, no era tan fácil poder apreciar la anatomía a través de los Rayos X, pues se obtenía una estructura plana en la que todos los elementos estaban en el mismo plano. A pesar de que la obtención de imágenes mediante Rayos X se fue poco a poco perfeccionando, siempre seguía existiendo falta de profundidad de campo.

Hounsfield desarrolló en 1967 una nueva técnica, la tomografía axial computarizada (TAC) que pudo ser utilizada en la clínica en 1973. Con el TAC se obtiene una imagen de una sección corporal, que en principio fue axial y de ahí su nombre; esta sección pudo ser escaneada y digitalizada. Poco a poco, esta técnica fue ganando en aspectos, tales como, mejora de aparatos para poder hacer el barrido del corte, modificación de los cortes, tiempo en efectuar la prueba, etc. Todo ello condujo a su utilización en la clínica, para el estudio de pacientes y también en la enseñanza de la Anatomía, ya que pone de manifiesto las diversas estructuras corporales de una manera topográfica, en un plano, pero pudiéndose estudiar diversos planos de forma secuencial. 
Por el mismo tiempo se empezó a utilizar la resonancia magnética (RM) para la obtención de imágenes corporales; no utiliza rayos X y, sí en cambio, campos magnéticos variables; fue en 1977 cuando Damadian obtuvo las primeras imágenes corporales en el individuo vivo.

Tanto las imágenes de TAC como las de RM les falta la tercera dimensión y así se suscitó la cuestión ¿cómo obtener imágenes en tres dimensiones (3D)?

El problema se solventó con la digitalización de estas imágenes, pues al ser tomográficas y estar digitalizadas, el ordenador puede apilarlas unas con otras y así reconstruir partes e incluso el cuerpo humano en 3D. Así se concibió el Proyecto del Human Visible, dirigido y realizado por la Nacional Library of Medicine (NLM) en Bethesda (Spitzer y cols., 1996) basado en la obtención de imágenes digitalizadas obtenidas de secciones consecutivas en el plano axial del cadáver de un cuerpo humano, varón, que había donado su cuerpo a la ciencia. Los datos se presentan en correlación con imágenes de RM y TAC. Un poco más tarde se amplió este estudio, mejorado, en el cadáver de una mujer anónima de 59 años. Con estos proyectos los datos anatómicos pueden ser aprendidos en una Anatomía tridimensional.

A estos modelos del Human Visible han seguido otros, como Chinese Visible Human Proyect (Zhang y cols., 2003), el Visible Korean Human (Park y cols., 2005) así como numerosas aplicaciones basadas en las imágenes del Visible Human, pues como dicen Spitzer y Scherzinger (2006) este proyecto permite visualizar, manipular y interactuar con imágenes.

Es importante y debe quedar claro, que la Anatomía 3D es específica de cada paciente. Ello permite a distintos especialistas como cirujanos y radiólogos, estudiar al propio paciente y les proporciona la disposición exacta de sus órganos, pues éstos pueden ser diferentes de unos individuos a otros.

La generación de imágenes 3D del cuerpo humano está sufriendo un incremento en los últimos años, habiéndose generalizando su uso en diferentes ámbitos médicos (Fielding y cols., 2000; Hoyte y cols., 2001). La implementación creciente de aplicaciones informáticas avanzadas, como la que 
se presenta en esta Tesis Doctoral, para la visualización de modelos-3D de estructuras anatómicas que constituyen el aparato dentario, permite comprender su estructura y relaciones espaciales. Entre otras muchas aplicaciones podemos citar las de Spitzer y Whitlock, (1998), Garg y cols., (1999), Jashtrow y Vollrath (2002), Bajka y cols., (2004), Parikh y cols., (2004), Robb y Hanson (2006), Temkin y cols., (2006), Zary y cols., (2009), Poulton y cols., (2009), Round y cols., (2009), Papadopoulos, (2010), Kononowicz y cols., (2012) Hege y cols., (2012) y, entre nosotros, Juanes y cols., (2003).

Una de las regiones corporales, de especial complejidad anatómica, es la cavidad oral, y su aparato dentario, caracterizada por contener estructuras morfológicas de soporte dental, en ocasiones difíciles de representar y comprender a partir de esquemas reproducidos en dos dimensiones.

La complejidad y amplitud de estructuras que abarca esta región anatómica hace que la patología (infecciones, anomalías congénitas, lesiones traumáticas y cicatriciales) sea igualmente abundante y difícil:

Odontopediatría: alteraciones del desarrollo de la dentición y la oclusión, caries, traumatismos, etc.

Ortodoncia: dientes impactados, asimetrías mandibulares, maloclusiones, agenesias, etc.

Patología de la oclusión: síndrome de disfunción craneomandibular, trastornos funcionales, rehabilitación oclusal, etc.

Patología y Terapéutica dental: procesos destructivos de los tejidos duros dentarios de etiología cariosa o no, alteraciones cromáticas, patología pulpar, etc.

Medicina bucal: enfermedades y lesiones de la mucosa bucal, cáncer oral, sida, quistes, tumores, inflamaciones glandulares, manifestaciones orales de otras enfermedades, patología lingual, etc.

Periodoncia: enfermedad periodontal. 
Odontogeriatría: enfermedades de la cavidad oral en el anciano.

Cirugía: exodoncia, dientes incluidos, frenillos, infecciones, traumatismos, quistes, tumores benignos, cáncer oral, tumores de las glándulas salivales, traumatismos, malformaciones craneomaxilofaciales, etc.

Es pues la relevancia de las funciones que realiza y la frecuente y variada patología que se observa en la clínica diaria, que requiere cada vez tratamientos más complejos, lo que acredita la importancia del conocimiento de la morfología humana normal y patológica de la cavidad bucal.

El aparato dentario lo constituyen unas piezas de considerable dureza y coloración blanquecina que inmersos en las cavidades alveolares de los maxilares, constituyen una unidad morfológica integrada en un complejo sistema funcional, el sistema masticatorio, con funciones fonéticas, estéticas, protectoras, etc., además de las propiamente masticatorias.

La Anatomía Humana es una materia fundamental para todos los profesionales de la salud, que precisan tener unos conocimientos generales de la estructura del cuerpo humano y ahondar en el entendimiento de aquellas partes del cuerpo que son esenciales para el desarrollo de su profesión. Así ocurre con odontólogos, estomatólogos, cirujanos maxilofaciales y otros profesionales cuyo campo de actuación se centra de forma permanente o eventual en la cavidad bucal.

La mayor revolución en el campo del radiodiagnóstico ha venido dada gracias a la introducción de técnicas informáticas asociadas a los equipos de diagnóstico por imagen (Zary y cols., 2009).

En la región que nos ocupa, técnicas como el DentaScan, han contribuido a conocer mejor la anatomía del aparato dentario (Lenguas y cols., 2010).

La capacidad actual, que las técnicas de tomografía computarizada ofrecen para el reconocimiento de estructuras anatómicas, hacen de esta técnica un 
excelente procedimiento diagnóstico por imagen, para el estudio normal y patológico del aparato dentario.

Para el odontólogo el conocimiento y visión tridimensional de las estructuras anatómicas que lo componen es tan esencial como su pericia en abordaje de esta zona corporal. Sin éste conocimiento exhaustivo de la anatomía tridimensional, la cirugía que efectúa el odontólogo deja de ser una ciencia y se convierte en un simple procedimiento técnico que puede ser peligroso para la paciente. Por tanto, el conocimiento anatómico debe formar parte de la base fundamental de todo odontólogo y/o estomatólogo.

Durante los últimos años se ha investigado intensamente con el objetivo de automatizar el análisis de imágenes médicas 3D para el apoyo de las tareas diagnósticas y terapéuticas. Sin embargo, las aplicaciones totalmente automáticas están lejos de hacerse realidad en un campo tan complejo como lo es el de la imagen médica 3D, por lo que la interacción manual aporta robustez y aumenta la utilidad de la aplicación (Eve y cols., 2014).

Si bien, existen muchos estudios morfológicos del aparato dentario, son escasos los datos que analizan con detalle, su anatomía tridimensional, mediante aplicaciones abiertas para la representación de escenas virtuales para plataformas Windows de bajo coste.

Tras realizar una exhaustiva revisión de la bibliografía médica (Medline, Index Medicus, Pub Med, Radiology, Radiographics, Gold Miner AARS, SpringerLink, Scopus, Science Direct, EMBASE, entre otras), sobre el tema propuesto como Tesis Doctoral, desde el punto de vista anatomorradiológico, hemos encontrado escasa bibliografía que estudie la anatomía del aparato dentario bajo entornos tridimensionales, dado que la mayoría de los estudios se centran en alguna porción en particular de este sistema dentario, y sobre todo en su vertiente patológica. Por lo tanto, nuestro el trabajo de Tesis Doctoral que planteamos y que hemos titulado "ENTORNO VIRTUAL DE VISUALIZACIÓN ANATÓMICA DEL APARATO DENTARIO, TRAS SU MODELADO TRIDIMENSIONAL CON TÉCNICAS RADIOLÓGICAS" 
supondrá una excelente herramienta para la visualización y análisis 3D de las estructuras anatómicas que forman parte del aparato dentario, con la posibilidad de valorarlas en cualquier posición espacial.

Los objetivos que nos hemos marcado con este procedimiento informático se basan en las siguientes consideraciones:

1. Potenciar sobre los usuarios que manejen nuestra aplicación informática, capacidades y destrezas a través de la utilización de los sistemas de simulación gráfica y visualización espacial.

2. Generar una herramienta de trabajo práctica para la identificación anatómica 3D y planificación quirúrgica ante posibles trastornos de las estructuras del aparato dentario.

3. Aumentar la motivación de profesionales odontólogos y estomatólogos, así como a estudiantes de odontología y/o medicina, etc., proporcionándoles una herramienta de aprendizaje y destreza en el conocimiento de las estructuras que conforman el aparato dentario.

4. Proporcionar conocimientos sobre la estructura del aparato dentario centrándonos en las relaciones anatómicas de las diversas estructuras morfológicas que configuran este sistema, mediante su visualización en diferentes posiciones espaciales y tridimensionalmente.

El desarrollo de aplicaciones informáticas avanzadas para el estudio de distintos aspectos anatómicos corporales, se está introduciendo de forma cada vez más progresiva, en el terreno de las ciencias de la salud, generándose programas informáticos muy valiosos para el estudio anatomo-radiológico. Las intervenciones asistidas por ordenador comienzan a ser una realidad en las actuaciones quirúrgicas $\mathrm{y}$, aunque es cierto que esto no ha hecho más que comenzar, parece evidente que su evolución es progresiva, avanzando a gran velocidad.

La aplicación informática que pretendemos desarrollar permitirá visualizar e interactuar simultáneamente con: 1) imágenes de las estructuras óseas que 
forman parte del aparato dentario, observándolas en los tres ejes ortogonales del espacio; 2) modelos-3D de superficie, que incluyen fundamentalmente estructuras óseas (maxilar superior y mandíbula), piezas dentarias y nervio dentario inferior o alveolar.

De esta manera, la aplicación informática que se propone como trabajo de Tesis Doctoral, esperamos que suponga un buen método de visualización 3D, teniendo como referencia secciones de tomografía computarizada en los tres planos del espacio, facilitando la valoración anatómica volumétrica, mediante el uso de las capacidades gráficas avanzadas que hoy en día ofrecen los ordenadores.

Para el desarrollo de nuestra aplicación informática, utilizaremos tecnología informática, de última generación, empleando para su elaboración, software de creación propia, así como estándares del mercado, con el fin de que el desarrollo informático se presente en un soporte compatible con la mayoría de los equipos informáticos y con las diferentes versiones del sistema operativo Windows, que disponen la mayor parte de los alumnos, así como en las diferentes clínicas odontológicas y en la mayor parte de los centros universitarios españoles.

En una primera fase de nuestro desarrollo, se recogerán las imágenes radiológicas procedentes de la tomografía computarizada de cráneos del Departamento de Anatomía e Histología Humanas de la Universidad de Salamanca, para la posterior identificación de las diferentes estructuras anatómicas que configuran el aparato dentario. Nos apoyaremos además, sobre reconstrucciones llevadas a cabo en cera, de piezas procedentes del Museo Anatómico de Valladolid, gentilmente cedidas por el Prof. Dr. D. Francisco Pastor Vázquez, responsable del museo.

Los modelos anatómicos 3D se visualizarán en un software, específicamente desarrollado por nosotros, programado en Visual C, que incluirá controles directX para la renderización de imágenes y modelos de malla triangular. Mediante la generación de un visor, podremos representar las escenas gráficas en cualquier orientación y almacenarlas en formato bitmap. 
Obtendremos así un primer prototipo, Beta 2, que incorporará ya todos los contenidos y las diferentes funcionalidades que conformarán el máster definitivo.

El software a desarrollar se orientará hacia un modelo centrado en el usuario, basándose en el autoaprendizaje y la autoformación en esta zona anatómica; además de servir de apoyo y orientación para odontólogos y estomatólogos en su practica clínica diaria

Por otra parte, el procedimiento informático que pretendemos llevar a cabo nos permitirá experimentar con medios que se adapten a la realidad tecnológica actual en las áreas de las ciencias médicas, por lo que al diseñar procedimientos virtuales para la formación docente y experiencia práctica de la anatomía del organismo humano, ayudará a simular situaciones que se presenten en distintos pacientes mediante procedimientos tecnológicos.

En definitiva, desarrollos informáticos, como el que proponemos, supondrán alcanzar otros muchos objetivos posteriores de interés, tales como:

- Ampliar la cobertura de la formación académica.

- Disminuir los costos en la formación.

- Simular situaciones clínicas, que en la realidad tendrían escasas posibilidades de realizarlas.

- Repetir eventos o fenómenos clínicos cuantas veces necesite el alumno.

- Desarrollar habilidades en el uso de la informática y las tecnologías docentes innovadoras.

A la hora de diseñar nuestra aplicación docente, partimos de la base de que nuestro procedimiento informático debería cumplir una serie de requisitos, entre los que destacamos: el ser de utilidad práctica para el usuario, el de permanencia en el tiempo, y el de innovación (arquitectura abierta e innovadora).

Por ello, el desarrollo informático propuesto lo elaboraremos en base a las siguientes directrices: 
Utilidad: que se desarrolle una herramienta útil para la valoración morfológica del aparato dentario, a través de un buen material interactivo basado en imágenes topográficas, procedentes de cráneos humanos, y su modelado tridimensional de las estructuras anatómicas que componen dicho aparato.

Usabilidad: que permita sincronizar y correlacionar la anatomía en 3D, mediante la generación de un visor apropiado.

Permanencia en el tiempo: que nos permita la actualización de contenidos, tanto de modelos anatómicos tridimensionales como de imágenes obtenidas por distintos procedimientos diagnósticos, lo que facilitará al usuario la creación de sus propias experiencias adquiridas en la clínica diaria.

Arquitectura abierta: que permita generar un material, sincronizado y documentado para elaborar un archivo iconográfico y audiovisual con fines docentes, informativos, etc., lo que conferirá, a esta herramienta, una dimensión absolutamente innovadora y radical, al no existir, en la actualidad, ninguna aplicación de características parecidas.

Innovación: que estemos ante un desarrollo informático totalmente innovador y de gran utilidad práctica en la docencia en ciencias de la salud, y en concreto en el campo de la odontología y la estomatología.

Finalmente, dada la amplia dispersión bibliográfica que existe sobre el aparato dentario, en virtud de las diferentes fuentes de procedencia, pretendemos llevar a cabo además, un análisis exhaustivo de dichas estructuras del aparato dentario, desde distintos puntos de vista, pero potenciando el estudio anatomoradiológico, con una visión y valoración tridimensional, al ser la menos empleada según demuestra el rastreo bibliográfico realizado. Por otro lado, llevaremos a cabo una amplia revisión bibliográfica que aporte al contenido de esta Tesis Doctoral, una adecuada visión de las distintas fuentes consultadas sobre la materia a estudio. 
Es evidente que cada día surgen nuevas plataformas informáticas como estructuras coordinadas de software y hardware que proveen la base para la construcción de sistemas de información para la formación clínica. La incorporación de las tecnologías informáticas al campo de las ciencias de la salud, supone un recurso útil y atractivo en cualquiera de sus especialidades. Por tanto, la formación y documentación con el apoyo de métodos tecnológicos, a través de programas informáticos interactivos, favorece el proceso de formación de los usuarios de estos recursos tecnológicos. 
MATERIAL y METODOS 
La metodología empleada en el presente trabajo de Tesis Doctoral se relaciona con dos tipos de procedimientos:

A.- Obtención del material gráfico y documental

B.-Implementación del aparato dentario en un sistema de visualización de imágenes tridimensionales, en un visor de DirectX, bajo la denominación $\mathrm{ViX}$

\section{1.- Material gráfico y documental}

El material gráfico generado ha incluido 2 tipos diferentes de objetos gráficos: 1) imágenes óseas (maxilar superior y mandíbula) generadas con tomografía computarizada; y 2) modelos tridimensionales (3D) de las diferentes piezas dentarias. También se ha reconstruido el nervio dentario inferior, a modo ejemplo de elemento modelable desde programas comerciales; sin necesidad de su visualización con técnicas de imagen diagnóstica. En cuanto al material documental, se ha procedido a elaborar breves descripciones relacionadas con las estructuras anatómicas modelizadas. Se describen a continuación las principales fases empleadas para la obtención de estos diferentes elementos.

\subsection{1.- Adquisición y procesamiento de imágenes de Tomografía Computarizada Multidetector}

Parámetros de adquisición

El tomógrafo utilizado para la realización de nuestro estudio fue un Asteion de 8 detectores (marca Toshiba Medical Systems) del Hospital Universitario de Salamanca (Figura 5) siguiendo el siguiente protocolo. Para el estudio del cráneo: uno en proyección ánteroposterior y otro en posición lateral, 
posteriormente se seleccionó un grosor e intervalo de corte de $1,5 \mathrm{~mm}$, adquiriéndose las imágenes helicoidales con reconstrucciones volumétricas del área de interés.
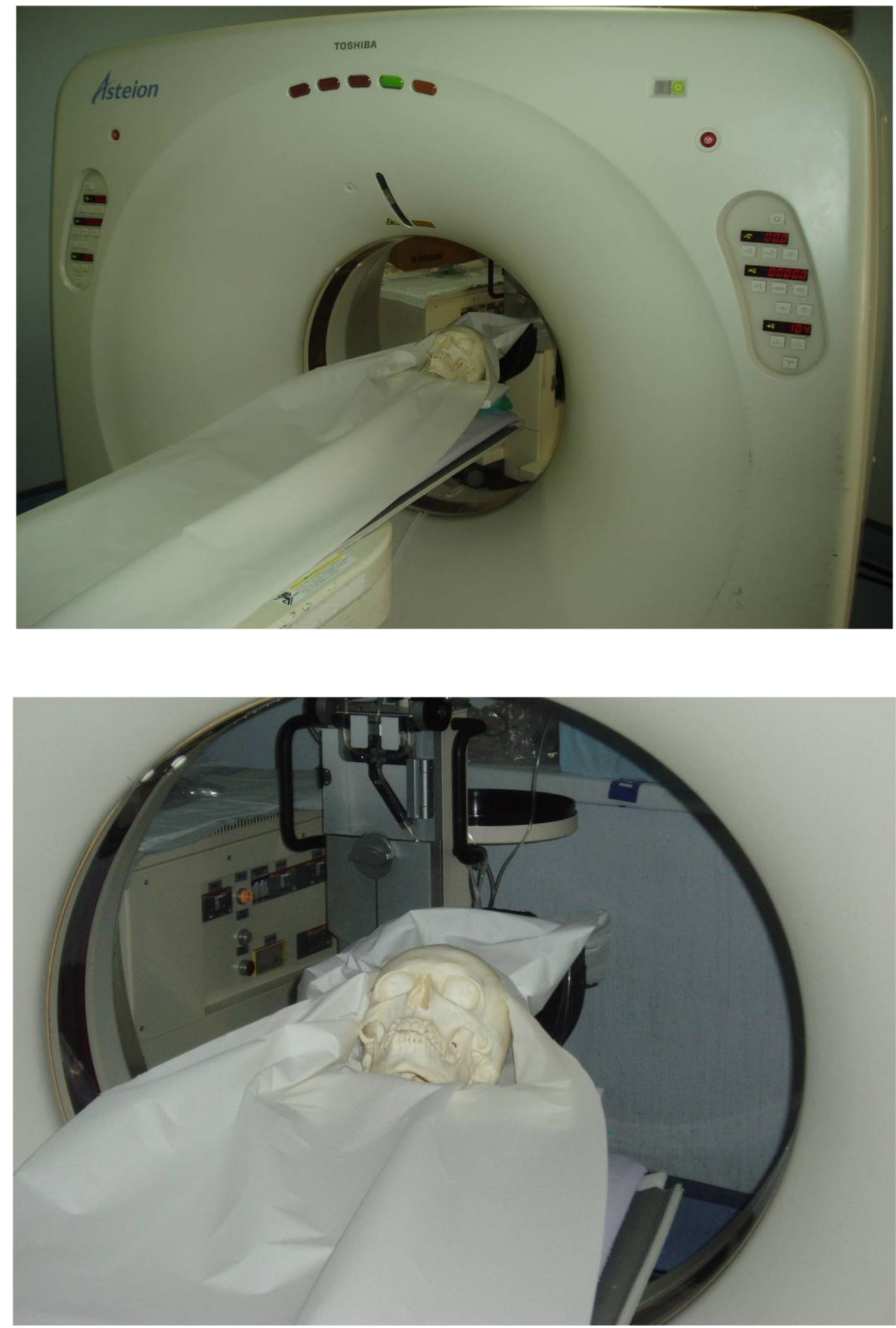

Figura 5.- Tomógrafo computarizado, modelo Asteion, de la casa comercial Toshiba Medical Systems, utilizado para la adquisición de diferentes imágenes DICOM, tanto de pacientes como de cráneos 
A partir de los ficheros raw data DICOM se reconstruyó, para cada orientación, un volumen que fue salvado en formato ANALYZE 7.5 mediante el software de libre distribución MRIcro (Nottingham, UK) (Figura 6).

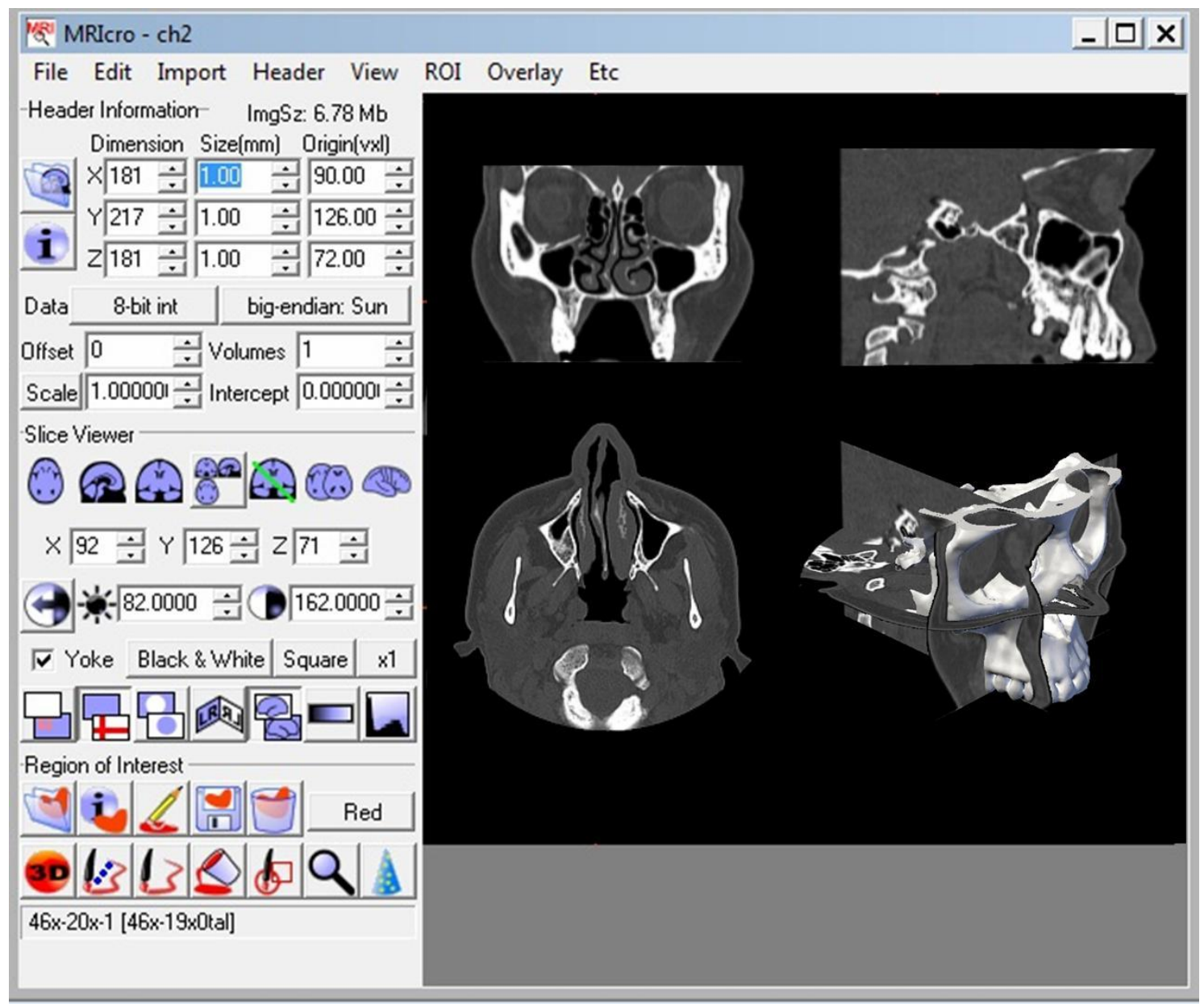

Figura 6.- Interface de usuario del software MRIcro (Nottingham, UK), para la manipulación y tratamiento de las imágenes DICOM obtenidas desde el tomógrafo computarizado

Alineación y redimensionamiento

Con la finalidad de homogeneizar al máximo las dimensiones entre los tres volúmenes, éstos fueron alineados, tomando como referencia el adquirido en el plano axial. A continuación se redimensionaron, aplicando un filtro Lanczos, resultando en un volumen axial de 600x560x30 slices (voxelsize= $0.5 \times 0.5 \times 3.5 \mathrm{~mm} 3$ ), un volumen sagital de 30x560x560 slices (voxelsize $3.5 \times 0.5 \times 0.5 \mathrm{~mm} 3$ ) y un volumen coronal de 600x28x560 slices (voxelsize 0.5x5.0x0.5 mm3). De cada uno de estos volúmenes se exportaron imágenes en 
formato PNG para su representación en un visor 3D (ver la sección visualización y renderización).

Así mismo, para facilitar la fase de modelización, los 3 volúmenes fueron redimensionamientos (reslicing), obteniéndose imágenes isotrópicas con vóxels de $1 \mathrm{~mm}$, es decir, con vóxels que poseen el mismo tamaño en todas las dimensiones.

\subsection{2.- Modelos 3-D}

Para la obtención de modelos 3-D de superficie, consistentes con modelos geométricos delimitados por mallas poligonales (triangulares), se han seguido las siguientes fases:

\section{Delimitación de regiones de interés}

Mediante un editor 3-D (Amira, 3.1; TGS Template Graphics Software) se procedió a delimitar en los volúmenes isométricos las regiones de interés (ROIs), también denominados labels, de las estructuras anatómicas a reconstruir (Figura 7).

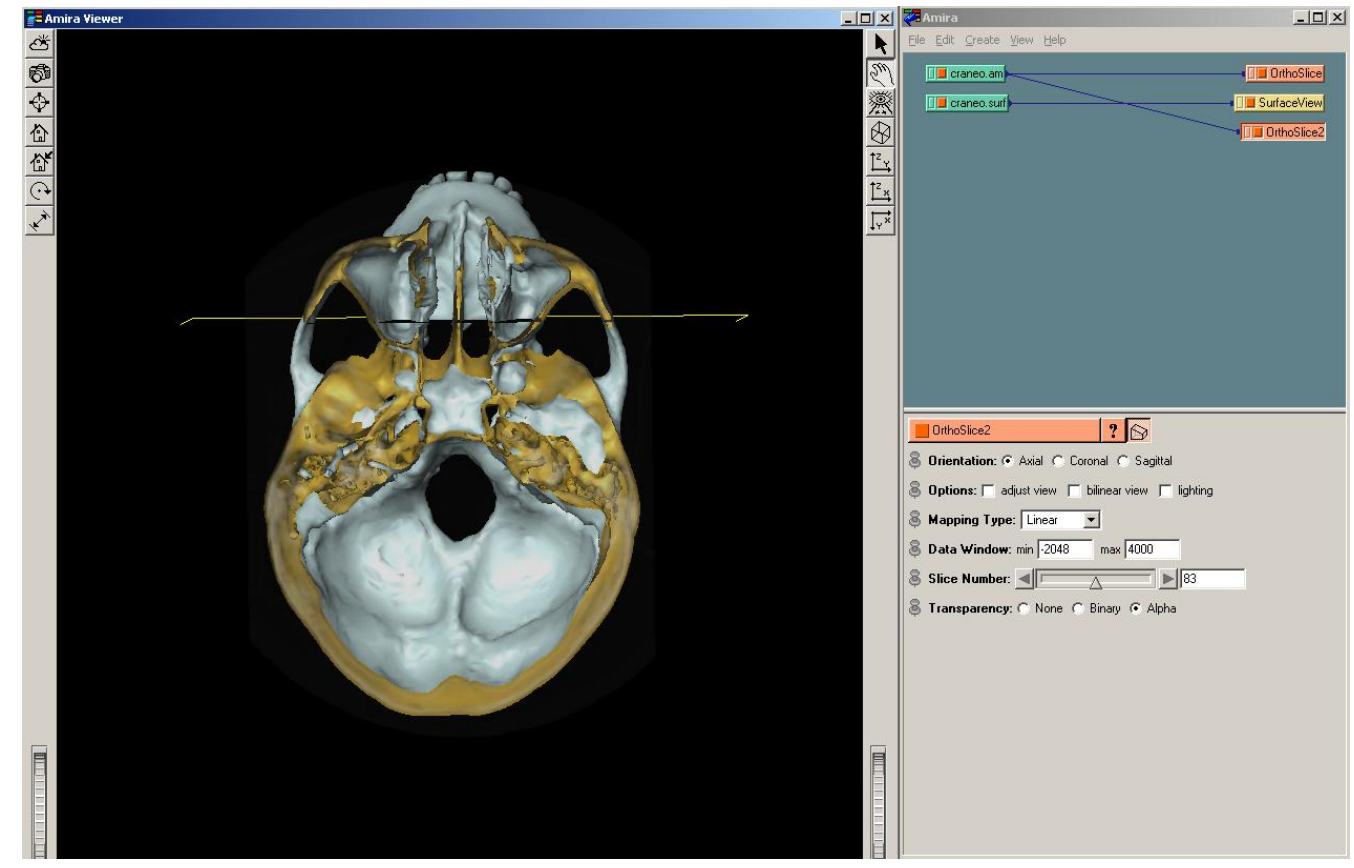

Figura 7.- Interface del editor 3-D Amira, para la delimitación de las regiones de interés (ROIs) 
Estas regiones han incluido:

\section{Estructuras óseas (Figura 8):}

a. Hueso maxilar superior

b. Mandíbula

c. Huesos vecinos: cigomático, nasales, etmoides, esfenoides, frontal, palatino

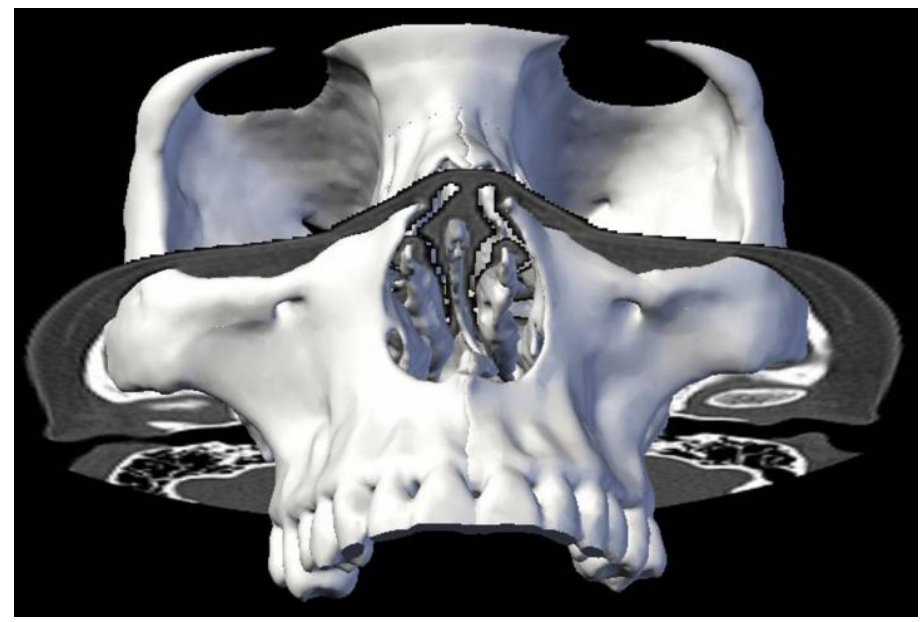

Figura 8.- Representación de la reconstrucción ósea tridimensional, embebidas en una sección axial de tomografía computarizada

\section{Estructuras dentarias.}

Modelado de cada una de las piezas dentarias de las dos arcadas (Figura 9):

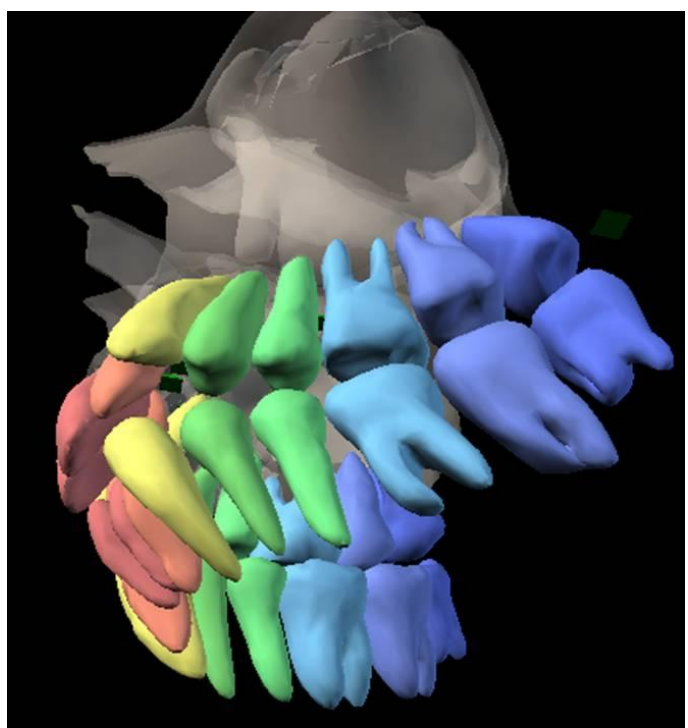

Figura 9.- Representación de la reconstrucción tridimensional del aparato dentario, con identificación en color de los diferentes grupos de dientes. Se ha eliminado el esqueleto maxilar superior y mandíbula. 


\section{Estructuras nerviosas.}

Nervio dentario inferior (Figura 10):

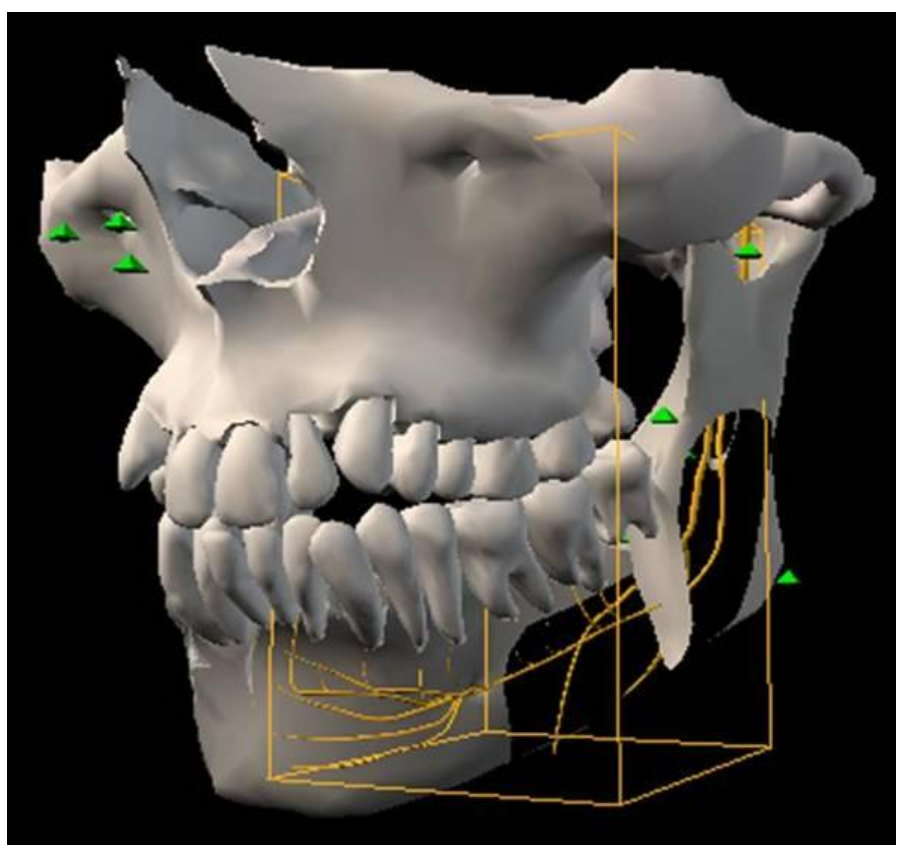

Figura 10.- Representación de la reconstrucción tridimensional del nervio dentario, con ventana abierta de la mandíbula para la valoración de su recorrido intramandibular.

\section{Generación de modelos $3 D$}

A partir de las ROIs, y aplicando un algoritmo conocido como marching cubes, se obtuvo un modelo de malla triangular de la superficie de cada una de estas estructuras identificadas (Figura 11).
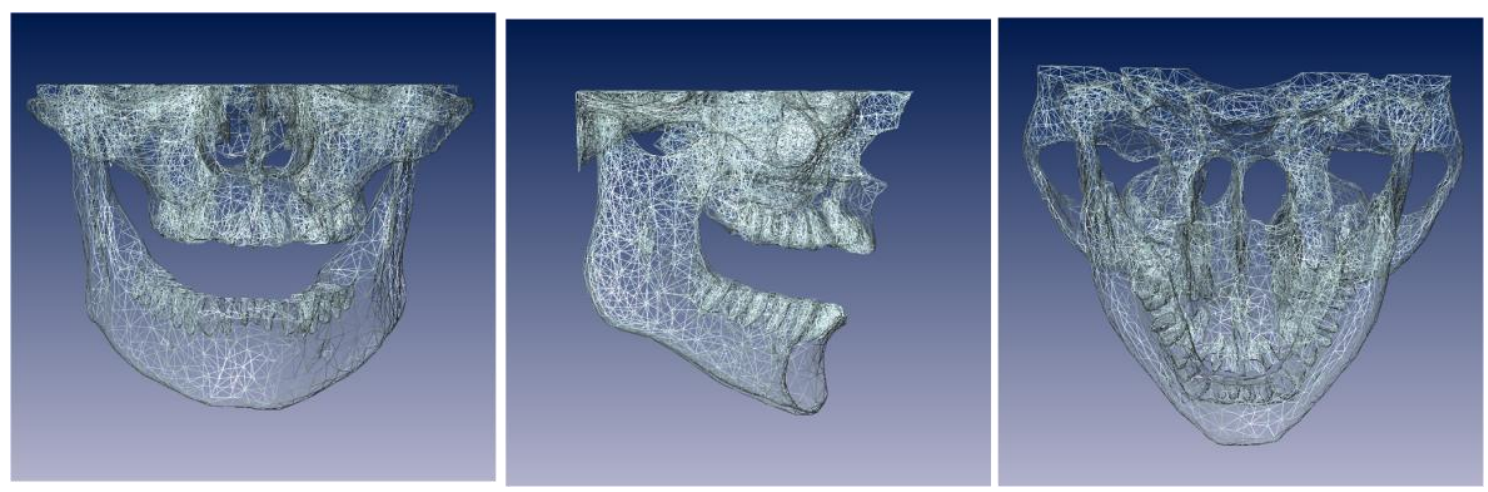

Figura 11.- Generación de modelos de superficie del esqueleto maxilar, a partir de las ROIs, aplicando algoritmos de 'marching cubes'. Modelado geométrico de malla triangular. 
Dada la alta resolución de las imágenes, se procedió a la simplificación y suavizado de la malla, obteniendo modelos poligonales que podían posteriormente editarse con mayor facilidad, mediante programas específicos de modelado (Autodesk Maya) (Figura 12).

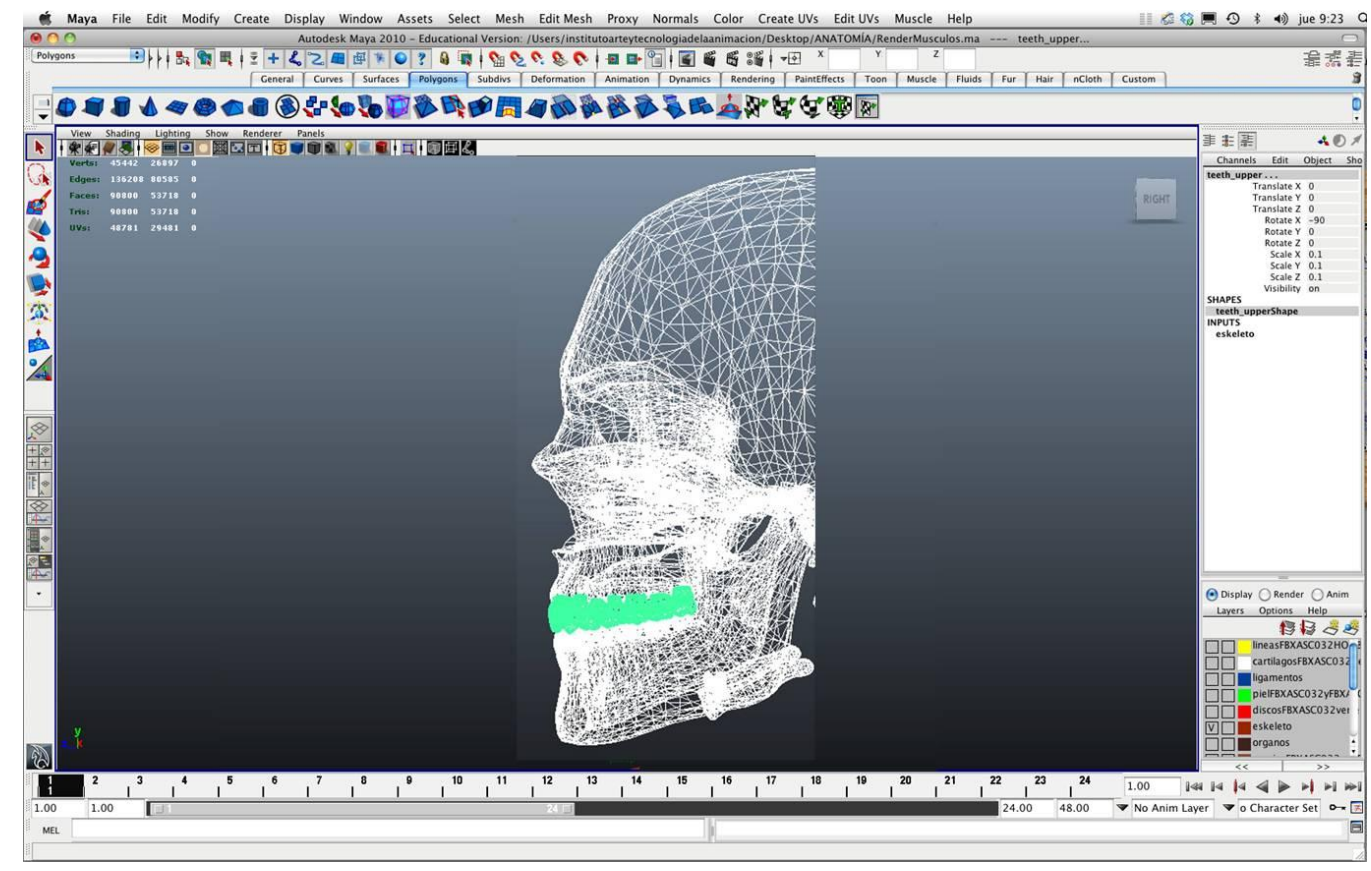

Figura 12.- Interface del software Autodesk Maya, para la simplificación y suavizado del modelado geométrico de malla triangular, que facilita un mejor manejo posterior en la aplicación informática final.

Finalmente los modelos 3D fueron exportados al formato directX, un formato gráfico estándar compatible con ViX, utilizando un programa de conversión (3D Exploration v 1.831, Right Hemisphere, Inc.; http://www.righthemisphere.com/3dexploration/).

\subsection{3.- Material documental}

Para cada uno de los modelos 3D reconstruidos se elaboró un fichero en formato html con una breve descripción anatómica (Figura 13). 


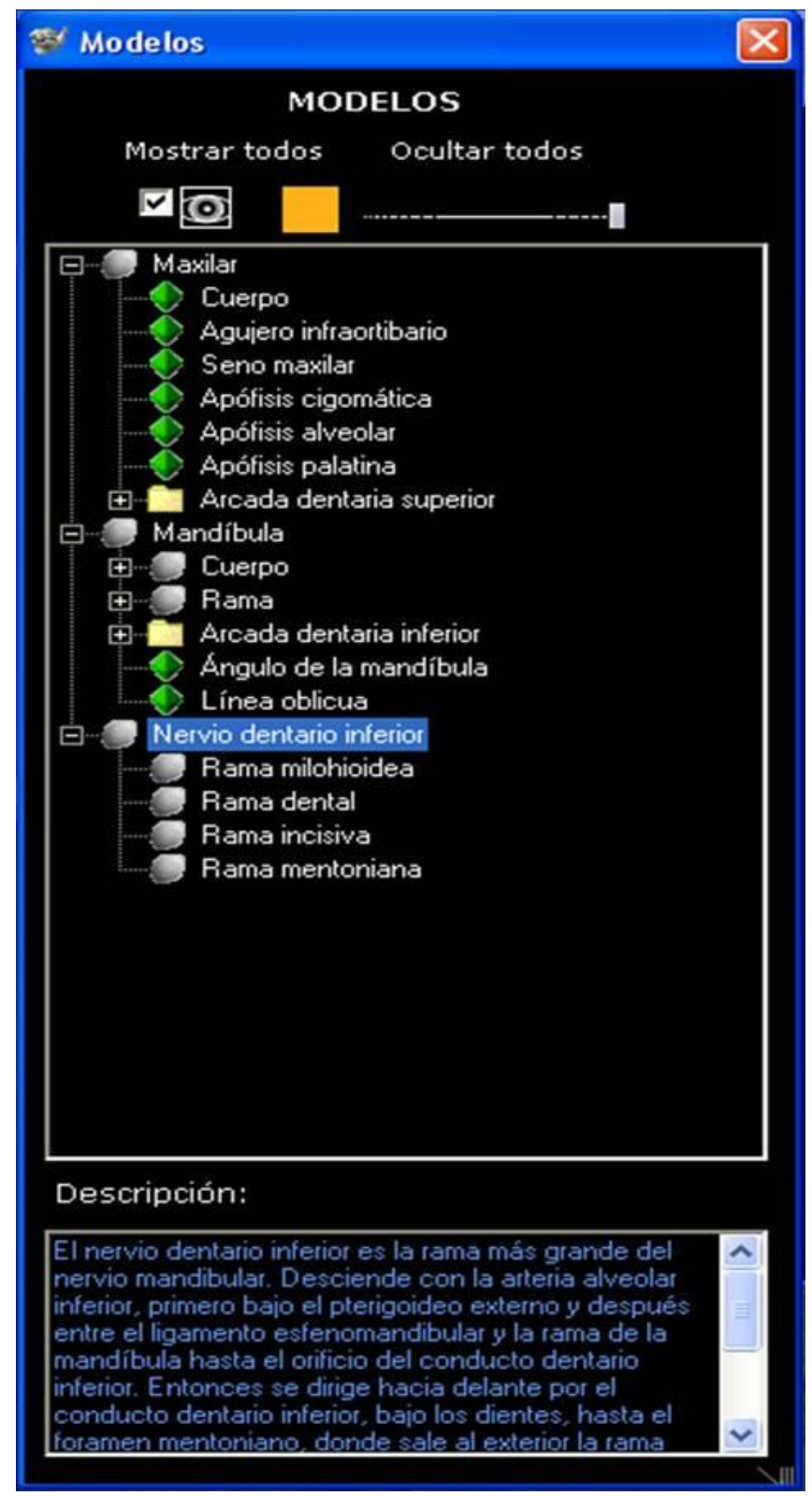

Figura 13.- Visualización del interface de usuario generado para la manipulación de los modelos anatómicos tridimensionales generados. Cada uno de ellos se describe, brevemente, en un recuadro en la parte inferior.

\section{2.- Implementación de la aplicación en el visor de DirectX}

Todo el aparato dentario fue implementado en un visor de directX, una aplicación de visualización que hemos generado, para entornos Windows, y programado en Visual C, que incluye controles ActiveX. Está diseñado para 
optimizar las capacidades de aceleración gráfica que soportan las tarjetas actuales.

La interface del visor de directX consta fundamentalmente de tres áreas que se pueden colocar en el monitor de forma libre (pantallas flotantes) (Figura 14):

- 1.- Visor 3D, para la representación de los diferentes elementos gráficos y modelos de superficie.

- 2.- Área de Control, con diferentes controles para la interacción con las imágenes y los modelos representados en el Visor (visibilidad, color del modelo).

- 3.- Selector de Escenas, menú desplegable mediante el que puede seleccionarse la escena virtual a representar, definida en un fichero de texto externo a la aplicación.

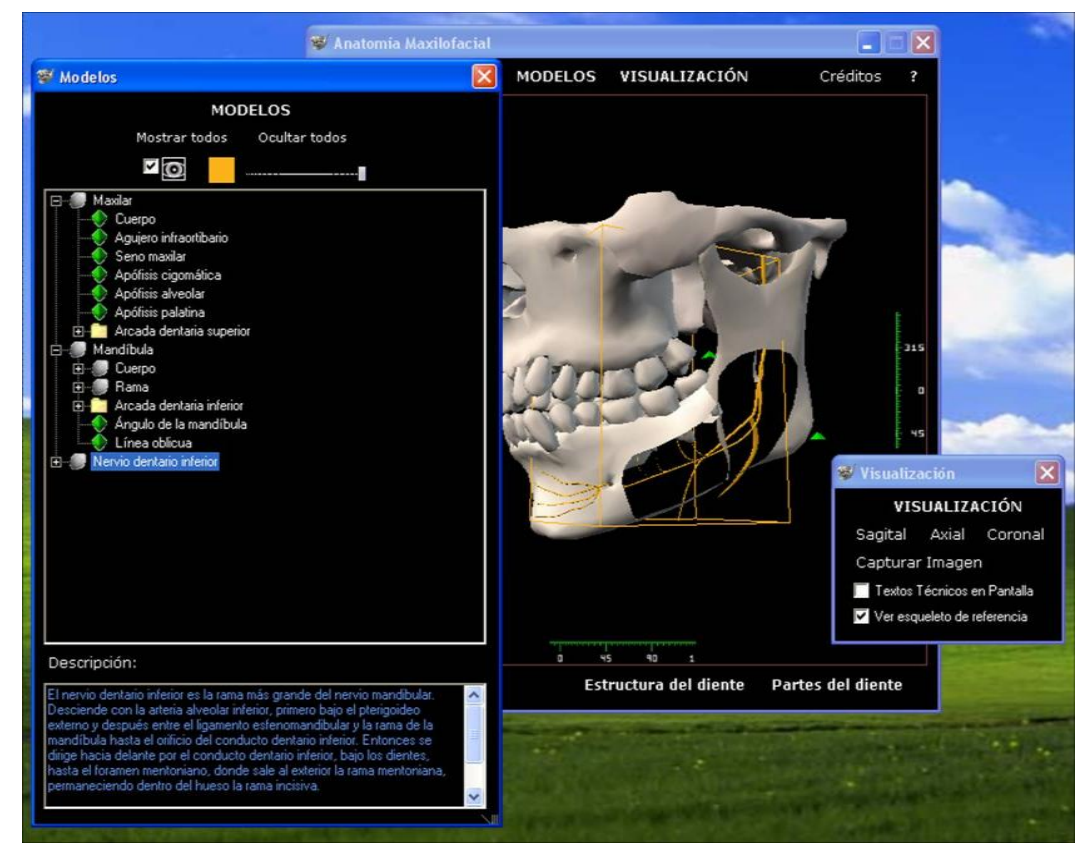

Figura 14.- Visualización del interface de usuario generado en la que se aprecian tres subpantallas flotantes, para la visualización en el plano espacial deseado y capturas de imágenes deseadas; pantalla de modelos 3D que el usuario podrá seleccionar libremente; y el propio Visor anatómico. 
Para la creación del aparato dentario se editaron dos ficheros de texto (utilizando un programa tipo WordPad) con la descripción de los elementos que constituyen la escena gráfica, que son interpretados por la aplicación ViX: un fichero de definición de imágenes y un fichero de definición de modelos.

\section{Fichero de definición de imágenes}

Este fichero contiene la información para disponer las imágenes en su orientación y posición espacial adecuada, que vienen determinadas por los siguientes parámetros:

- Dimension (x, y, z): indica la dimensión total del volumen del que se han obtenido las imágenes, es decir, el número total de slices (300x280x280)

- Pixelsize (x, y, z): tamaño del vóxel, en cada dirección espacial, expresado en milímetros $(1 \mathrm{mmx} 1 \mathrm{mmx} 1 \mathrm{~mm})$

- $\operatorname{Origin}$ (x, y, z): origen -centro de referencia- del volumen $(148,131,139)$

- Orientación: puede ser Sagittal, Coronal o Axial.

- Nombre del fichero de imagen, seguido del slice al que corresponde

Fichero de definición de modelos

Se trata de un fichero de texto, que contiene las especificaciones de cada modelo 3D.

Los principales nodos empleados en este tipo de fichero son los siguientes:

- Model. Define la creación de un nuevo modelo, cuyas características se especifican entre llaves.

- Name. Nombre con el que aparecerá el modelo en los menús desplegables de selección.

- Label. Identificador de modelo, para uso interno. 
- File. Fichero en formato DirectX con la geometría del modelo

- Color. Color del modelo, en escala RGB, con valores de cada componente entre 0 y 1

- TransparencyRange. Permite especificar el rango de variación del factor de transparencia. Generalmente 0 para objetos no transparentes y 1 para la máxima transparencia.

- Transparency. Factor de transparencia inicial del modelo.

- DrawStyle. Especifica el estilo con el que se representa la malla poligonal, que puede seleccionarse entre dibujo sombreado (shaded) o de líneas (lines).

- Visible. Nodo empleado para definir la visibilidad inicial del modelo. El valor 0 indica No visible y el valor 1, visible.

- Documentation. Fichero en formato html que contiene la documentación asociada al modelo.

\section{3.- Programación en Visual C++}

La programación se llevó a cabo mediante el software Visual C++, el cual, como entorno integrado de desarrollo, nos permitió realizar una programación orientada a objetos (POO) bajo los lenguajes de programación $\mathrm{C}$, $\mathrm{C}++$ y $\mathrm{C}++/ \mathrm{CLI}$, conjuntamente con el sistema de desarrollo SDK (también denominado API) de Windows.

Visual C++ nos permitió el desarrollo y la depuración de código escrito para las API's de Microsoft Windows, DirectX y tecnología Microsoft .NET Framework.

Por otra parte, al tratarse de un entorno integrado, Visual $\mathrm{C}++$ nos permitió utilizar otras herramientas complementarias de desarrollo:

- Editor orientado a la codificación C/C++

- Compilador/Enlazador incremental, que aceleró el proceso de construcción de nuestro desarrollo informático. 
- Depurador visual, que permitió visualizar y modificar el contenido de variables y áreas de memoria.

- Visor de datos (browser) que permitió fácilmente controlar dependencias y referencias a funciones, datos, etc. Además permitió visualizar la jerarquía de las clases utilizadas en el programa.

- Herramientas adicionales como un analizador de ventanas (Spy ++) o un trazador de funciones MFC (Microsoft Foundation Classes).

Visual C++ incluye la librería de clases MFC que permite crear y gestionar de manera intuitiva componentes típicos de Windows. Esto es, la MFC es una implementación que utiliza el API encapsulando todas las estructuras y llamadas a funciones en objetos fáciles de utilizar. En este sentido y, basándose en la potencia de la MFC, Visual $\mathrm{C}++$ se convierte así en un generador de programas $\mathrm{C}++$ para Windows.

De esta manera, el lenguaje de programación que hemos utilizado para esta aplicación informática, es compatible en la mayor parte de su código con este lenguaje, a la vez que su sintaxis es exactamente igual.

Para crear cualquier programa con Visual $\mathrm{C}++$ debemos comenzar creando un proyecto para él, codificando y añadiendo los módulos necesarios a dicho proyecto, y definiendo los recursos asociados.

En Visual $\mathrm{C}++$, la construcción de nuestro procedimiento informático se inscribe dentro del concepto de proyecto (workspace). Un proyecto define los pasos a seguir para alcanzar la construcción de un objetivo (un programa, una DLL, etc.), en realidad es un concepto análogo a lo que se conoce como "makefile" en otros entornos típicos de desarrollo en C. En realidad, Visual C++ genera para cada proyecto dos ficheros que lo definen, el fichero de workspace (con extensión wsp) y un makefile (con extensión mak) estándar que permitiría la utilización del mismo proyecto en otro entorno distinto. 
Desde el punto de vista funcional, el proyecto contiene referencias a cada uno de los ficheros fuentes $(\mathrm{C} / \mathrm{C}++$, con extensiones c y cpp respectivamente), objetos, librerías o ficheros de recursos (extensión rc) que se deben utilizar para construir el objetivo final del proyecto.

Todo el procedimiento informático finalmente fue empaquetado para su montaje en soporte CD-ROM, para su instalación en ordenadores con sistemas operativos Windows.

Los requerimientos técnicos, tanto de hardware como de software son los siguientes:

Hardware mínimo:

Tarjeta gráfica con al menos $32 \mathrm{Mb}$ de memoria (recomendado $64 \mathrm{mb}$ ) que soporte DirectX 9.0 en modo ventana con transparencias.

Pentium III a $450 \mathrm{Mhz}$ (recomendado $600 \mathrm{Mhz}$ o superior)

$128 \mathrm{Mb}$ de memória RAM (recomendado $256 \mathrm{Mb}$ o superior)

$40 \mathrm{Mb}$ de memeoria libre em disco duro.

Software necesario:

Sistema operativo Microsoft Windows 2000, XP, o superior

Software de DirectX 9.0 o superior

Microsoft NET Framework 2.0 o superior

\section{4.- Encuesta de satisfacción}

Nuestro modelo informático fue testado por distintos profesionales del área de la odontología, estomatología y cirujanos maxilofaciales. El total de profesionales voluntarios fueron 30 , distribuidos de la siguiente forma: del ámbito de la odontología (15), estomatología (10) y cirugía maxilofacial (5) de diferentes centros privados y hospitalarios nacionales. 
Además, con el objetivo de valorar la eficacia de nuestra aplicación informática, sobre estudiantes del ámbito de la odontología, se practicaron otras encuestas de satisfacción a 15 alumnos voluntarios, del último curso de la Licenciatura de Odontología.

Para esta valoración del desarrollo informático, se llevó a cabo una encuesta de satisfacción con el objetivo de analizar y comprobar su eficacia.

La encuesta se llevó a cabo con los diferentes ítems según se trataran de profesionales o de estudiantes, al ser para estos últimos, preguntas más específicas hacia el ámbito formativo.

Las preguntas formuladas se reflejan en la tabla adjunta.

Para los profesionales sanitarios, la encuesta presentó las siguientes cuestiones:

Valore el grado en que está de acuerdo con las siguientes cuestiones

( 1 = Totalmente en desacuerdo, $5=$ totalmente de acuerdo):

\begin{tabular}{|c|c|c|c|c|c|c|}
\hline $1^{\mathrm{a}}$ & El programa informático es útil como recuerdo anatómico rápido & 1 & 2 & 3 & 4 & 5 \\
\hline $2^{\mathrm{a}}$ & Resulta práctico para mostrar a los pacientes & 1 & 2 & 3 & 4 & 5 \\
\hline $3^{\mathrm{a}}$ & El interface de usuario es de fácil manejo y atractivo & 1 & 2 & 3 & 4 & 5 \\
\hline $4^{\mathrm{a}}$ & La visualización 3D facilita la comprensión & 1 & 2 & 3 & 4 & 5 \\
\hline $5^{a}$ & El contenido incorporado es abundante & 1 & 2 & 3 & 4 & 5 \\
\hline $6^{\mathrm{a}}$ & $\begin{array}{l}\text { Recomendaría este tipo de recurso tecnológico de visión 3D a mis } \\
\text { colegas como apoyo en las planificaciones clínicas }\end{array}$ & 1 & 2 & 3 & 4 & 5 \\
\hline
\end{tabular}

Para la encuesta de los estudiantes del último curso de la Licenciatura, los ítems formulados fueron los siguientes:

Valore el grado en que está de acuerdo con las siguientes cuestiones $(1$ = Totalmente en desacuerdo, 5 = totalmente de acuerdo $)$ :

\begin{tabular}{|c|c|c|c|c|c|c|}
\hline $1^{\mathrm{a}}$ & Considero que el programa informático es útil para mi formación & 1 & 2 & 3 & 4 & 5 \\
\hline $2^{a}$ & La metodología empleada motiva mi aprendizaje & 1 & 2 & 3 & 4 & 5 \\
\hline $3^{\mathrm{a}}$ & La interface del programa, lo considero de fácil manejo y atractivo & 1 & 2 & 3 & 4 & 5 \\
\hline $4^{\mathrm{a}}$ & $\begin{array}{l}\text { Se han hecho visualizaciones de estructuras anatómicas que } \\
\text { facilitan la comprensión }\end{array}$ & 1 & 2 & 3 & 4 & 5 \\
\hline $5^{\mathrm{a}}$ & El contenido incorporado es adecuado & 1 & 2 & 3 & 4 & 5 \\
\hline $6^{a}$ & Con este medio tecnológico he aprovechado mi estudio & 1 & 2 & 3 & 4 & 5 \\
\hline $7^{a}$ & Este procedimiento complementa mi formación odontológica & 1 & 2 & 3 & 4 & 5 \\
\hline $8^{\mathrm{a}}$ & $\begin{array}{l}\text { Recomendaría este tipo de recurso adicional de aprendizaje } \\
\text { autónomo }\end{array}$ & 1 & 2 & 3 & 4 & 5 \\
\hline
\end{tabular}


El formato de respuesta para todos los ítems formulados fue el siguiente:

1 , totalmente en desacuerdo; 2 , parcialmente en desacuerdo; 3 , ni en desacuerdo ni de acuerdo; 4, parcialmente de acuerdo; y 5, totalmente de acuerdo. 


\section{RESULTADOS}


Nuestro desarrollo informático permite representar e interactuar con 2 tipos de elementos visuales principales: Modelos y Visualización de escena. (Figura 15), que se podrán ubicar por cualquier parte de la pantalla, al ser elementos flotantes.

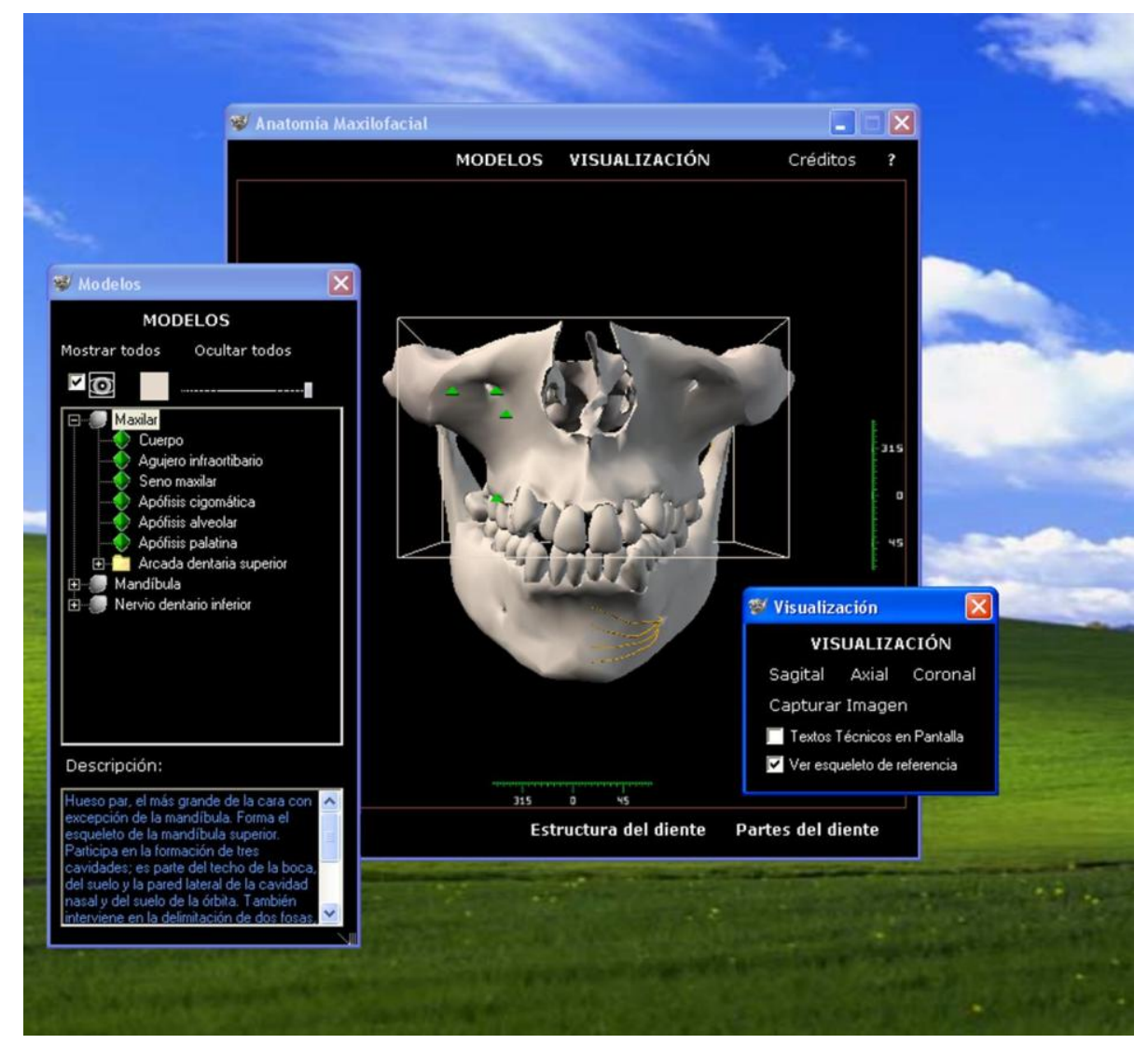

Figura 15.- Visualización de las diferentes pantallas flotantes con las que puede interactuar el usuario.

Todas las interacciones con los elementos de la escena visual (rotaciones, traslaciones, zoom y selección) se realizan situando el cursor sobre el visor, usando el ratón.

\section{Rotaciones:}

Para rotar la imagen del visor, mantener pulsado el botón principal (izquierdo) del ratón mientras se desplaza el cursor sobre la pantalla. (Figura 16).

\section{Traslaciones:}

Para trasladar la imagen del visor en el plano de la pantalla, mantener pulsados los dos botones del ratón mientras se desplaza el cursor. 


\section{Zoom:}

Para ampliar o reducir el tamaño de la imagen que se muestra en el visor, mantener presionado el botón secundario del ratón desplazando el cursor hacia arriba (ampliar) o hacia abajo (reducir).

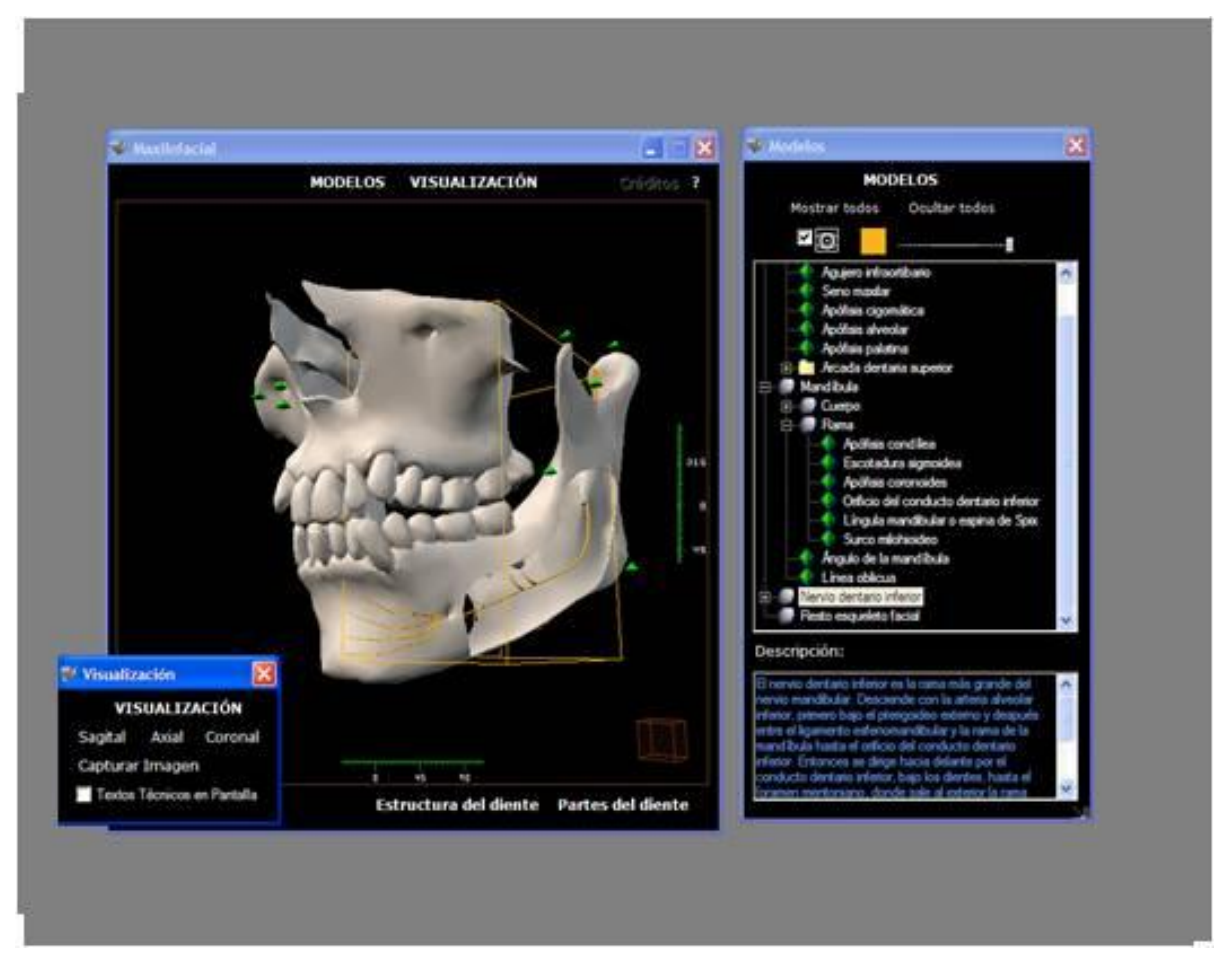

Figura 16.- Imagen de visor 3D que permite visualizar los modelos en cualquier posición espacial con los movimientos del ratón (rotaciones, traslaciones, ampliación, etc...)

\section{Selección:}

Haciendo clic en el visor, sin mover el ratón, se seleccionará el modelo sobre el que se pulse.

El modelo seleccionado se puede desplazar a lo largo de su eje manteniendo pulsada la tecla mayúsculas, mientras desplaza el ratón por la pantalla sin mantener pulsado ningún otro botón del ratón.

La vista resultante de realizar rotaciones, traslaciones o zoom puede ser almacenada mediante fichero a través del botón al efecto, que permite guardar la escena representada en el visor en un fichero con formato bitmap (.bmp), mediante la opción capturar imagen, situada en la parte superior de la columna de acciones. (Figura 17). 


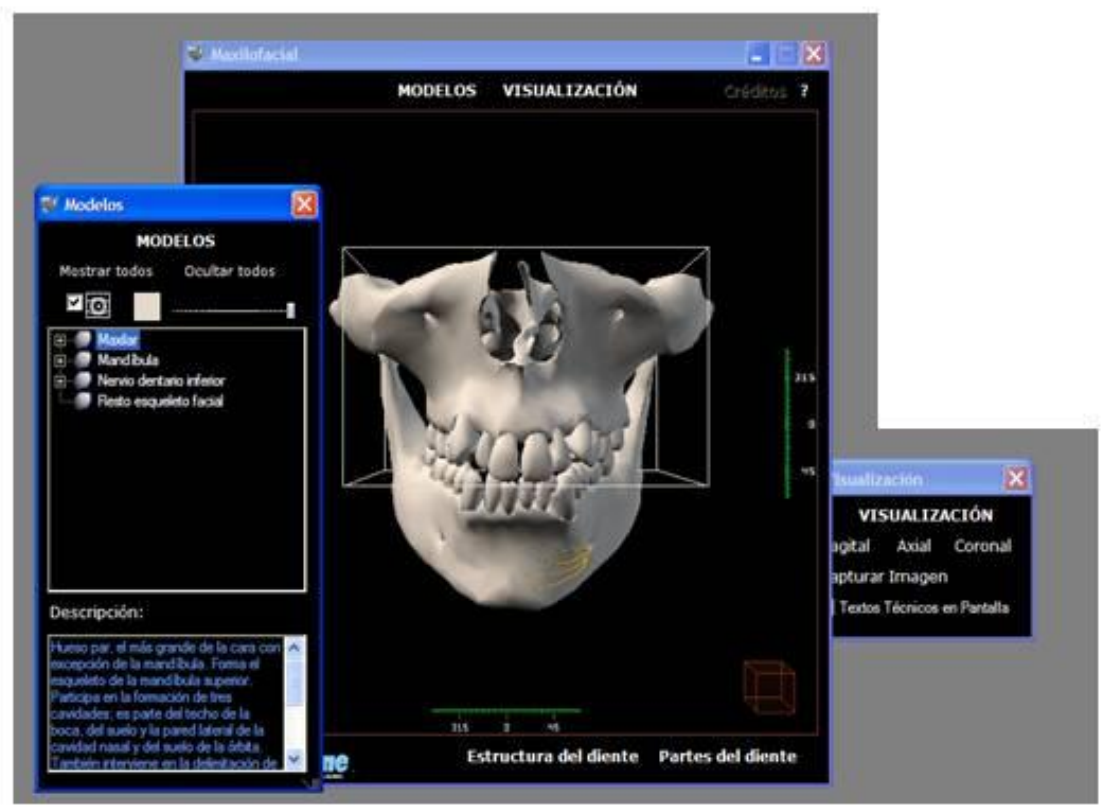

Figura 17.- La ventana de visualización de nuestra aplicación informática permite la captura de la imagen generada en el visor 3D, almacenándose en formato bitmap. Además ofrece la posibilidad de visualizar la imagen en diferentes planos espaciales. La ventana Modelos activa las estructuras anatómicas en 3D que deseamos visualizar.

Existen tres planos de orientación: Plano Sagital (lateral), Plano Axial (horizontal) y Plano Coronal (frontal); estas opciones se muestran en la opción de visualización (Figura 17).

Cada plano posee un control de selección para activar o desactivar su visibilidad, (Figura 17); también podremos cambiar la posición del plano seleccionado, moviendo el cursor horizontalmente sobre el visor, mientras se pulsa Mayúsculas, sin mantener pulsado ningún botón del ratón.

El botón Modelos (Figura 17) controla las estructuras anatómicas del aparato dentario, representadas mediante modelos tridimensionales (3D).

Los botones Mostrar Todos y Ocultar Todos (Figura 17), permiten de una forma rápida ver cómo se integran perfectamente los modelos en el visor (si éstos están visibles) así como hacer desaparecer todos los modelos 3D del visor. 
Podremos en la configuración, seleccionar / deseleccionar los modelos de forma independiente e ir visualizándolos según la selección realizada al efecto en el apartado del desplegable, donde se podrá observar la lista de todas las estructuras (modelos 3D) disponibles. El cuadro de selección Visible permite activar o desactivar la visibilidad del modelo seleccionado, que aparecerá enmarcado en su color. Seleccionando sobre el color podremos modificar éste. Pueden seleccionarse sucesivamente varios modelos para su visualización simultánea. Con el deslizador podremos controlar la opacidad y transparencia del modelo (Figura 18).

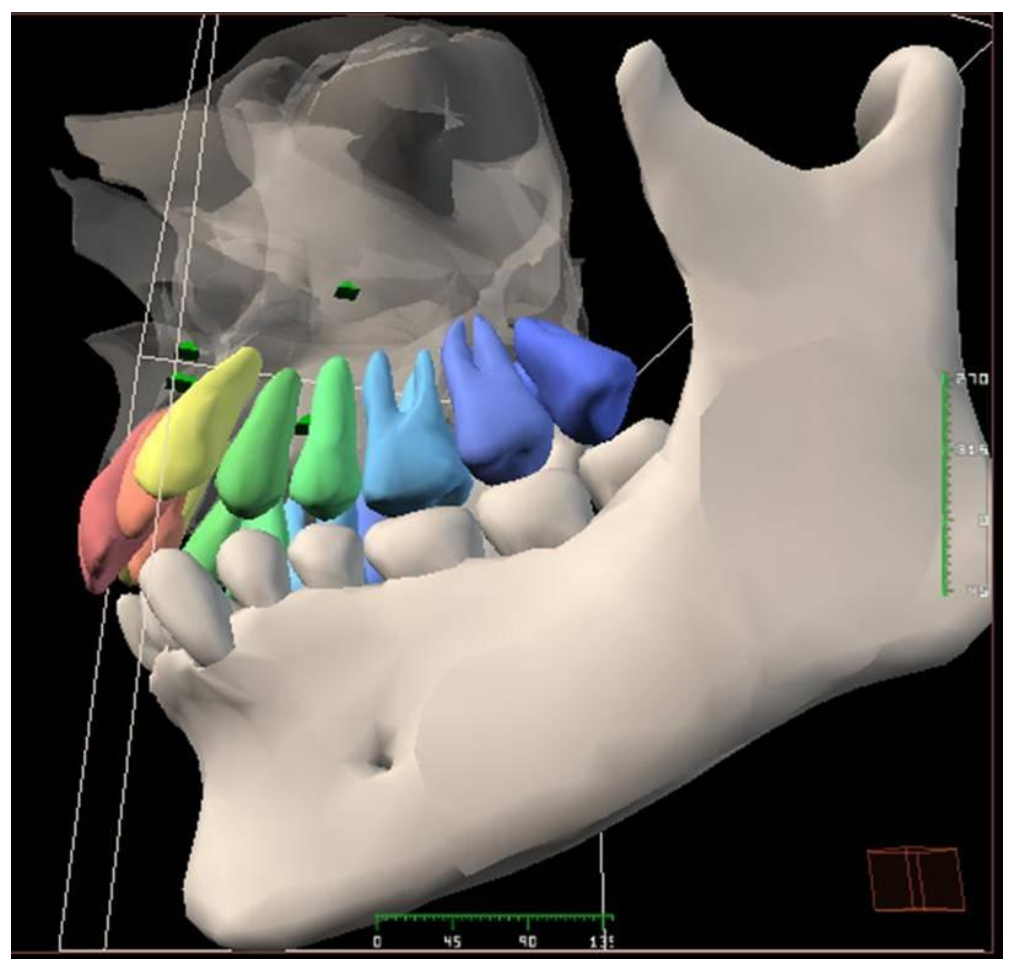

Figura 18.- Imagen 3D del visor anatómico que permite observar cada una de las estructuras anatómicas volumétricas en el color deseado e individualizarlas del resto. La posibilidad de practicar opacidades y/o transparencias de cada modelo 3D, facilita las relaciones espaciales de cada estructura.

El cuadro de texto inferior muestra una breve descripción en relación con el modelo anatómico 3D seleccionado (Figura 17).

Para ocultar la información científica y técnica mostrada en pantalla, habrá que pulsar sobre la opción Textos técnicos en pantalla 
Todo nuestro sistema informático, está controlado a la voluntad del usuario, por lo tanto existe una verdadera interacción entre el ordenador y el usuario, evitando, en la medida de lo posible, que éste último se convierta en mero espectador. De esta forma, el usuario podrá ir analizando cada una de las principales estructuras del aparato dentario susceptibles de poder ser reconstruidas tridimensionalmente y que pasaremos a describir de forma breve.

Comenzaremos por la descripción de los dos maxilares.

\section{1.- Maxilar superior (Figura 23)}

Corresponde al hueso central del macizo facial superior (Figura 19), el cual se articula con los demás huesos de dicho macizo, con el frontal, el etmoides y el esfenoides y contiene los senos maxilares.

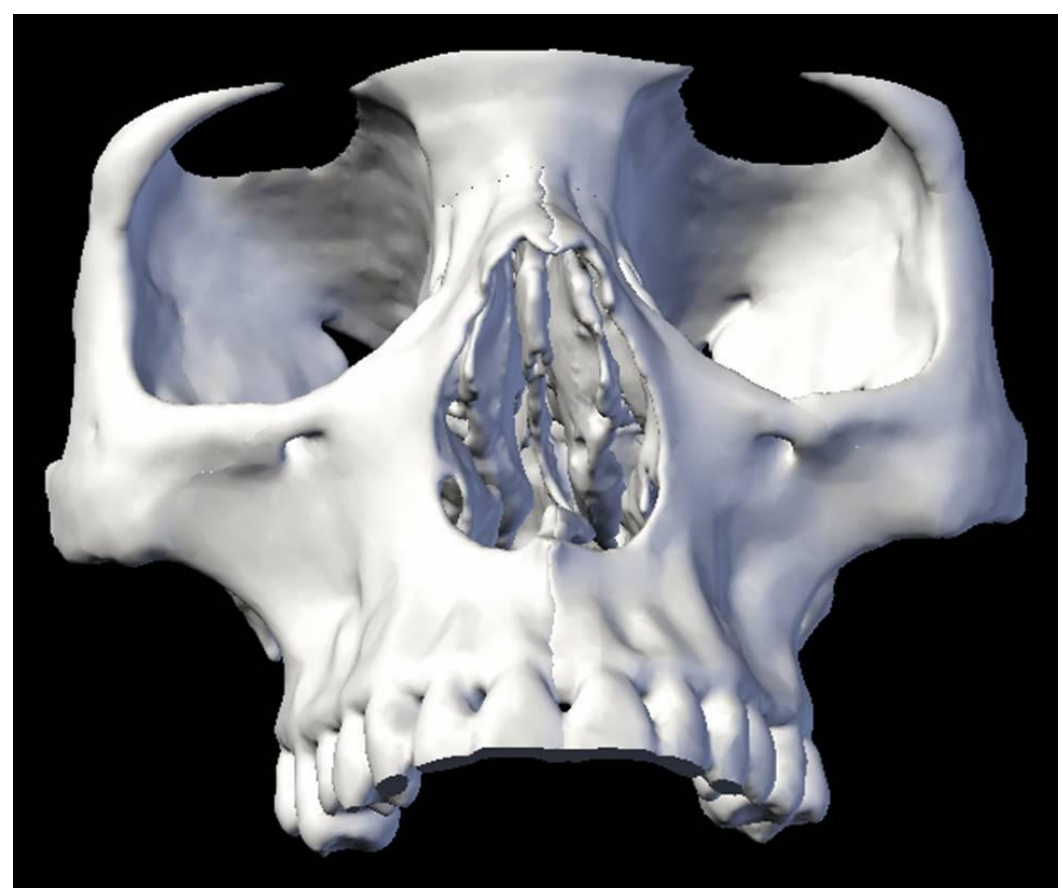

Figura 19.- Representación volumétrica de la reconstrucción tridimensional del parte del macizo facial, generadas desde secciones de tomografía computarizada.

Morfológicamente distinguimos:

Cara externa (Figura 20): que presenta en su borde inferior eminencias verticales que corresponden a las raíces de los dientes. Ocupando su parte media 
y superior encontramos la apófisis piramidal, con una cara superior u orbitaria que contiene el canal y conducto suborbitario que termina en la cara anterior de la apófisis por el agujero suborbitario del que parte un nuevo conducto por cuyo interior transcurre el nervio dentario anterior que inerva los dientes anteriores del arco superior. En esta cara anterior de la apófisis piramidal también se encuentra la fosita canina donde se inserta el músculo canino. En la cara posterior, que forma parte de la fosa cigomática, se encuentran los agujeros dentarios posteriores para el paso de los nervios dentarios posteriores. La apófisis piramidal separa una porción anterior, en la que encontramos la fosilla mirtiforme y la eminencia canina, y otra posterior que es la tuberosidad del maxilar.

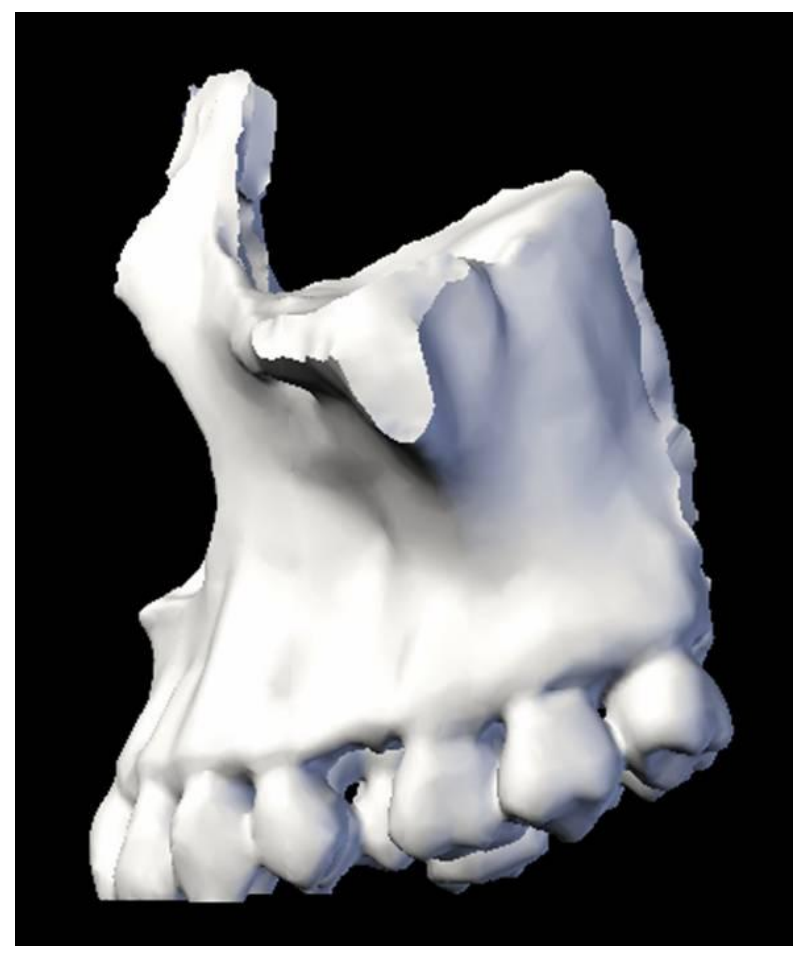

Figura 20.- Visión 3D de la cara externa del maxilar superior, generada desde secciones seriadas de tomografía computarizada

Cara interna o nasal (Figura 21): dividida por una apófisis horizontal (la apófisis palatina, que con la ayuda de las láminas horizontales de los huesos palatinos, constituye la bóveda palatina) en una porción superior mayor, que 
forma parte de las fosas nasales y en la que se observa el orificio de entrada del seno maxilar, y una porción inferior que forma la estructura ósea de la bóveda palatina.

Cara superior: forma parte del suelo de la órbita, se continúa por su parte externa con la cara superior de la apófisis piramidal, desprendiéndose de su parte más anterior e interna la apófisis ascendente que llega hasta el frontal entre el unguis y el hueso propio de la nariz.

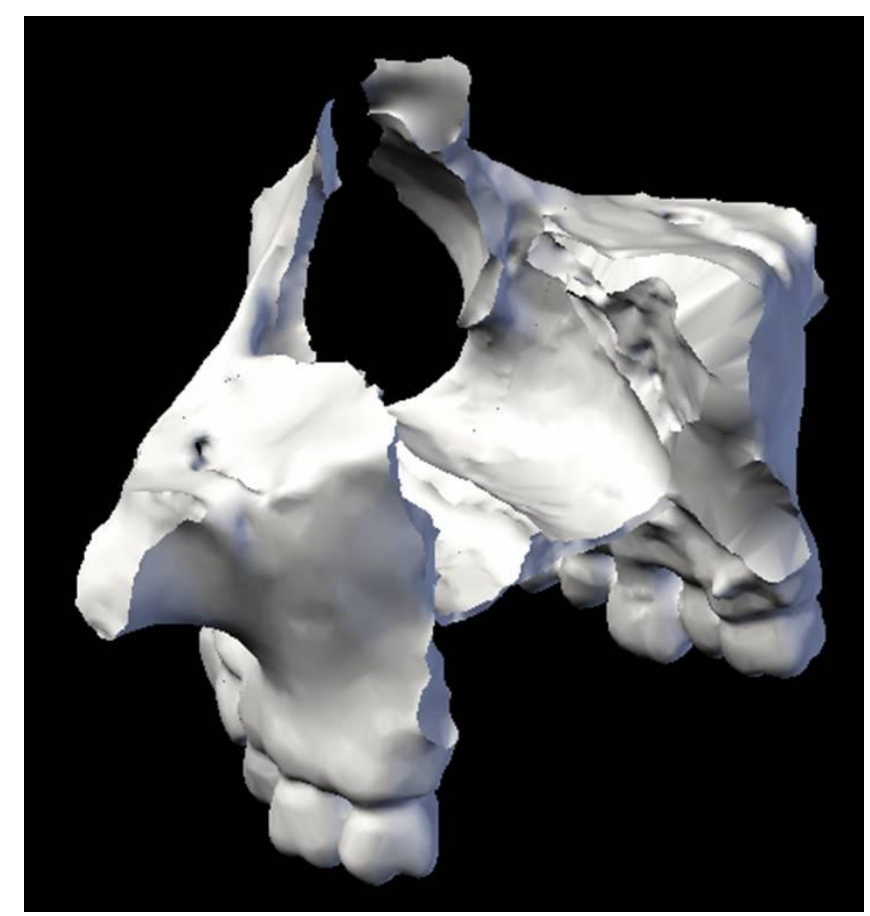

Figura 21.- Visión 3D de la cara supero-interna del maxilar superior, generada desde secciones seriadas de tomografía computarizada

Borde anterior: que da forma a la semiespina nasal anterior y a la escotadura nasal.

Borde posterior: que se articula con el palatino.

Borde inferior o alveolar (Figura 22): formado por las cavidades alveolares en las que se implantan los dientes de la arcada superior. 


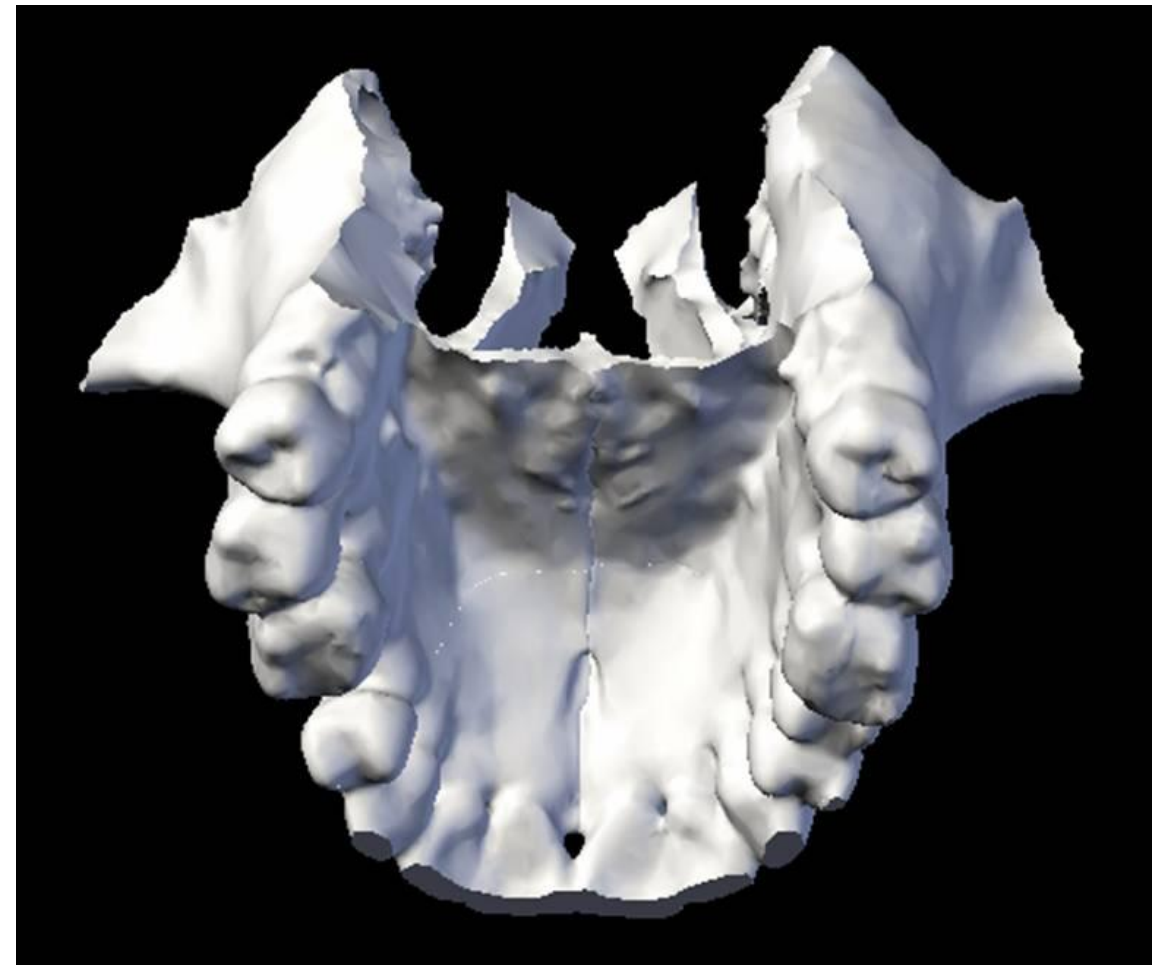

Figura 22.- Visión 3D de la cara inferior del maxilar superior, generada desde secciones seriadas de tomografía computarizada 
Resultados
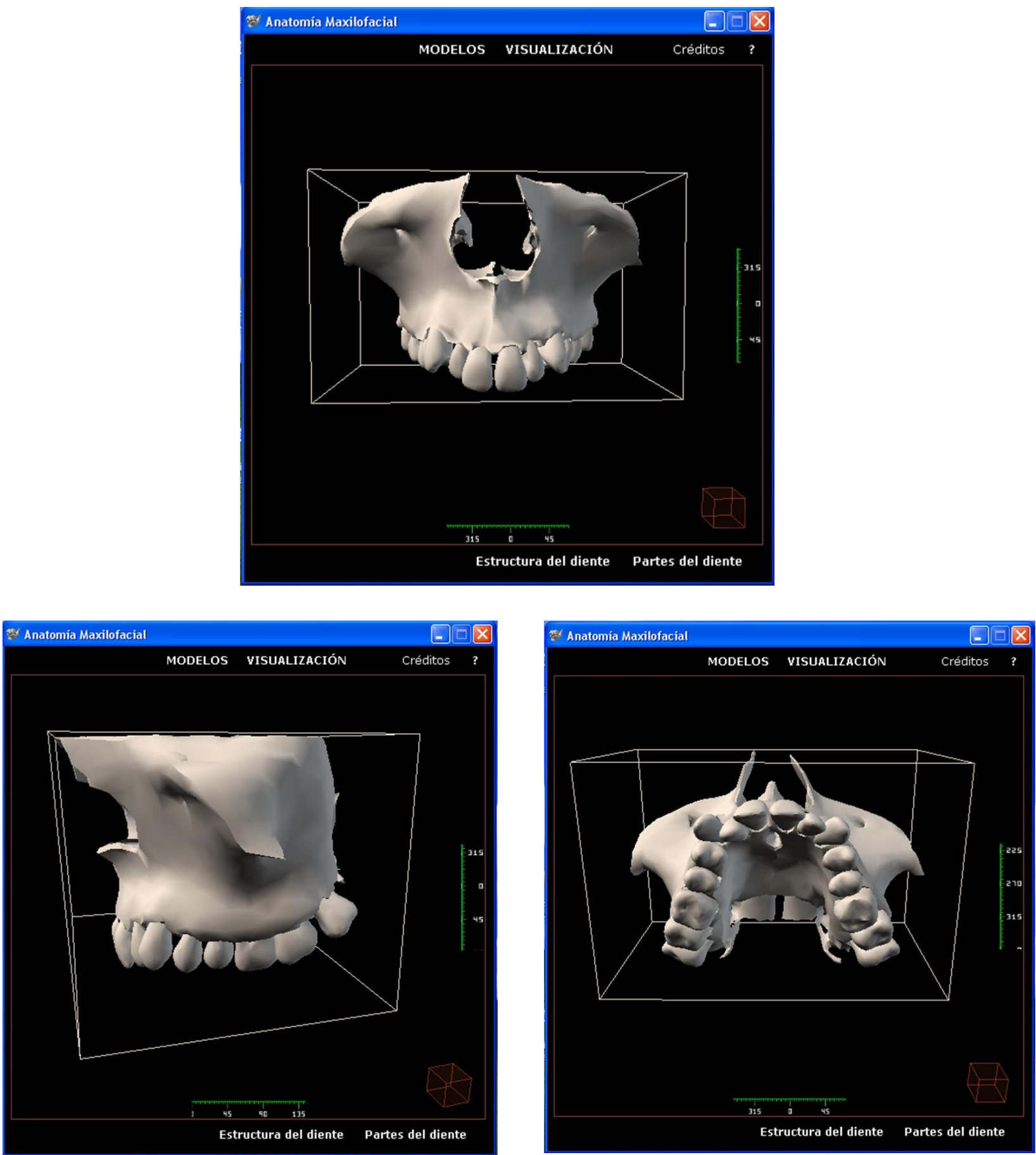

Figura 23.- Representación visual del maxilar superior en diferentes posiciones espaciales, observadas desde el visor anatómico. 


\section{2.- Maxilar inferior o mandíbula}

Hueso impar que forma por sí solo el armazón óseo del macizo facial inferior (Figura 24). Podemos distinguir una parte media o cuerpo y dos prolongaciones o ramas ascendentes.

\section{Cuerpo:}

Con forma de herradura abierta hacia atrás, distinguimos:

Cara externa: presenta una depresión longitudinal y media, la sínfisis mentoniana, signo de la unión embriológica de las dos hemimandíbulas, y que termina inferiormente en una prominencia redondeada, la eminencia mentoniana, de la que parte una cresta, la línea oblicua externa, que se dirige hacia arriba y hacia atrás, continuándose con el borde anterior. Por encima de esta línea y a nivel del segundo premolar se encuentra el agujero mentoniano por el que discurren los nervios y vasos mentonianos.

Cara interna: presenta en la línea media y cerca del borde inferior cuatro pequeñas eminencias superpuestas dos a dos, las apófisis geni superiores e inferiores, lugar de inserción de los músculos geni.

Desde la parte media y dirigiéndose hacia arriba y hacia atrás hasta el borde anterior de la rama ascendente se encuentra una rugosidad diagonal, la línea oblicua interna o milohioidea, lugar de inserción del músculo homónimo. Esta línea, divide la cara interna del hueso en una fosita superior y anterior denominada sublingual y otra posterior e inferior, la fosita submaxilar.

Reborde superior o alveolar: que contiene las cavidades o alvéolos en los que se implantan los dientes inferiores.

Borde inferior: redondeado, presenta por delante, próxima a la sínfisis mentoniana, la fosita digástrica, en la que se inserta el vientre anterior del músculo digástrico. Ocasionalmente se puede encontrar, en su unión con el borde inferior de la rama ascendente, un surco para el paso de la arteria facial. 
Ramas ascendentes:

Son dos láminas irregulares de forma cuadrangular, aplanadas de fuera adentro, dispuestas a ambos lados del cuerpo y con una dirección oblicua de abajo arriba y de delante atrás.

Cara externa: con una parte inferior rugosa por la inserción del músculo masetero.

Cara interna: con un ángulo inferior igualmente rugoso por la inserción del músculo pterigoideo interno. Hacia su mitad presenta el orifico superior del conducto dentario, por el que penetran los nervios y vasos dentarios inferiores que desembocarán en la cara externa del cuerpo mandibular a nivel del agujero mentoniano. Cubriendo por delante este orificio encontramos una lámina ósea triangular, la lámina de Spix, y por debajo parte el canal milohioideo, para los vasos y nervio milohioideo.

Borde posterior: contorneado, romo y describe una curva en S itálica. Se relaciona con la glándula parótida por lo que se le conoce también como borde parotídeo.

Borde inferior: forma el ángulo del hueso y se continua con el borde inferior del cuerpo.

Borde superior: de disposición ligeramente oblicua de delante atrás y de dentro afuera, presenta dos eminencias: una posterior, el cóndilo mandibular, y otra anterior, la apófisis coronoides, separadas por una profunda escotadura, la escotadura sigmoidea.

- El cóndilo mandibular: eminencia elipsoidea, convexa en toda su extensión excepto en su parte anterior, cóncava, en la que se inserta el músculo pterigoideo externo. Su cara superior, en ángulo diedro, se articula con el temporal. Ligeramente aplanado de delante atrás y 
dirigido oblicuamente hacia delante y hacia fuera, está unido a la rama ascendente por una parte estrecha, el cuello del cóndilo.

- La apófisis coronoides, lámina vertical aplanada de fuera adentro, de forma triangular con base inferior, en la que se inserta el músculo temporal.

- La escotadura sigmoidea, con forma de semiluna cóncava hacia arriba, a través de la cual pasarán estructuras vasculares y nerviosas. 
Resultados

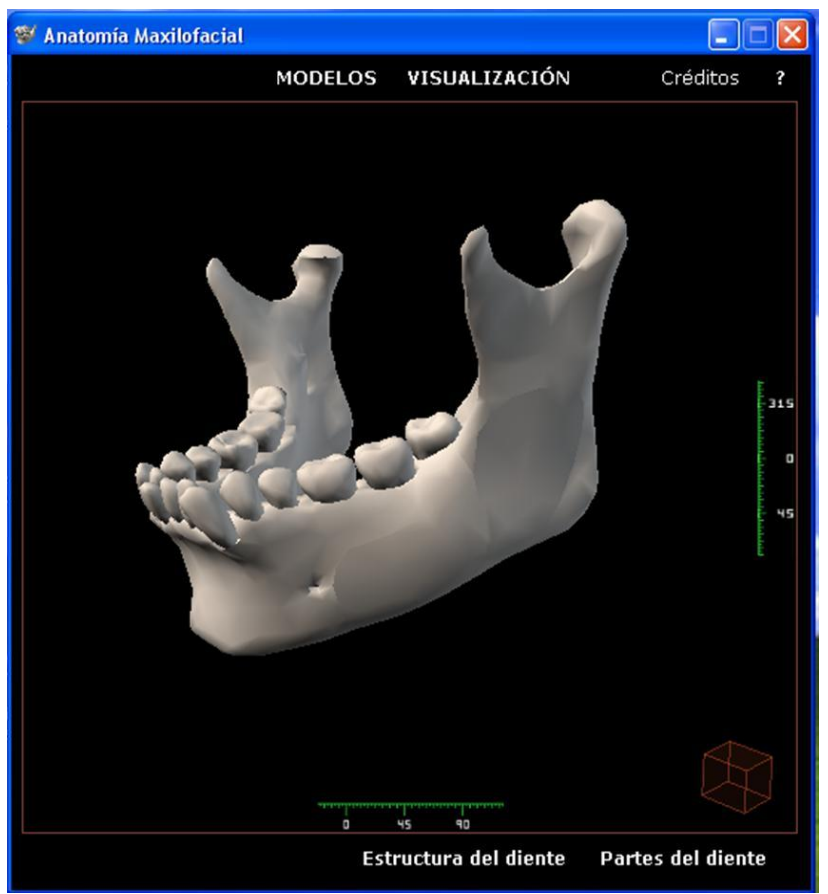

A

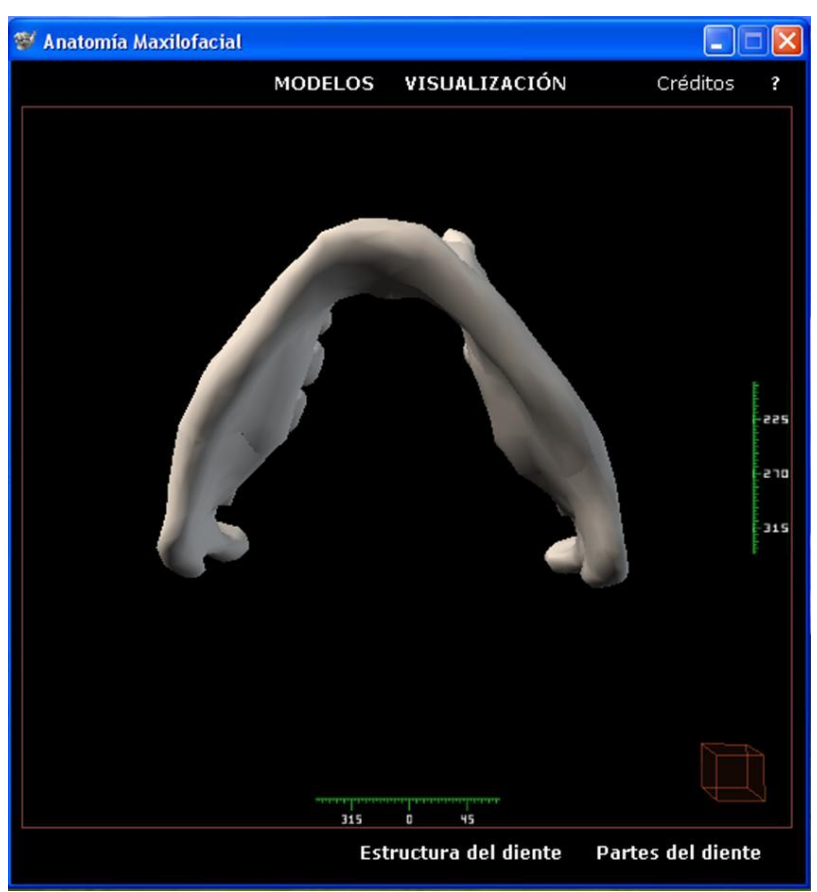

B

Figura 24.- Representación tridimensional de la mandíbula en diferentes posiciones espaciales, observadas desde el visor anatómico. A. Visión lateral. B. Visión inferior. C. Visión Posterior. D. Visión superior.

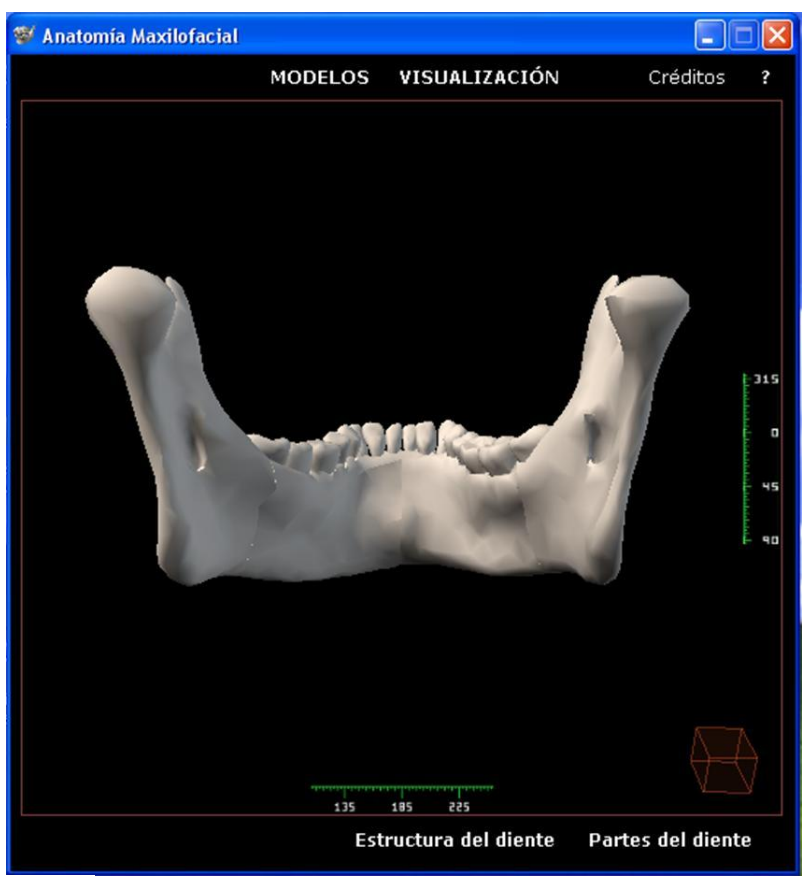

C

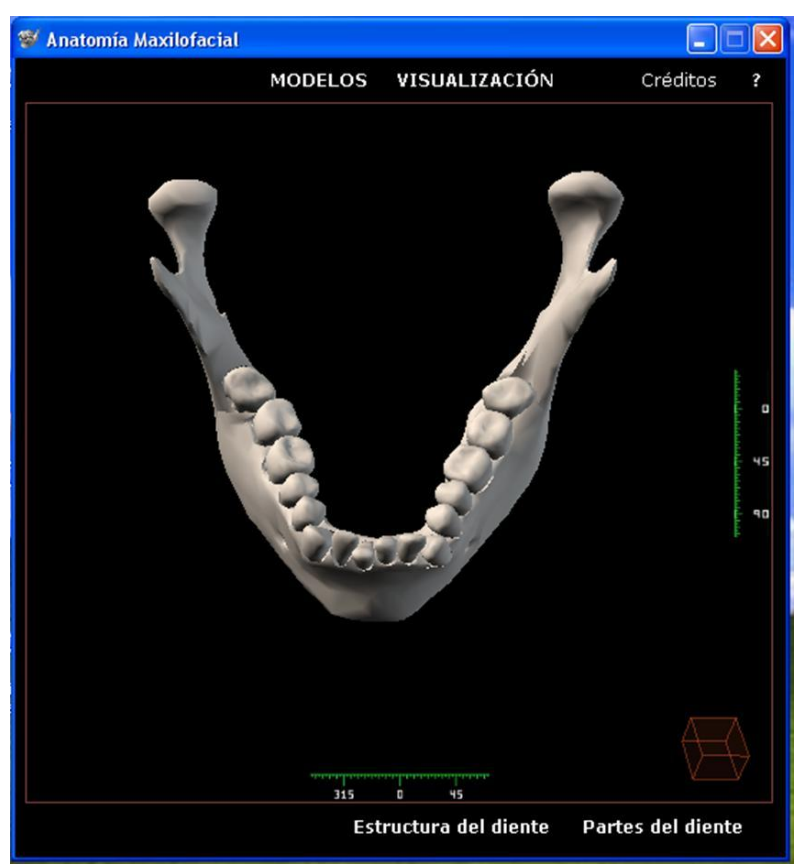

D 


\section{3.- Aparato dentario}

Los dientes son órganos de considerable dureza y coloración blanquecina que inmersos en las cavidades alveolares de los maxilares (Figura 25), constituyen una unidad morfológica integrada en un complejo sistema funcional, el sistema masticatorio, con funciones fonéticas, estéticas, protectoras, etc., además de las propiamente masticatorias.
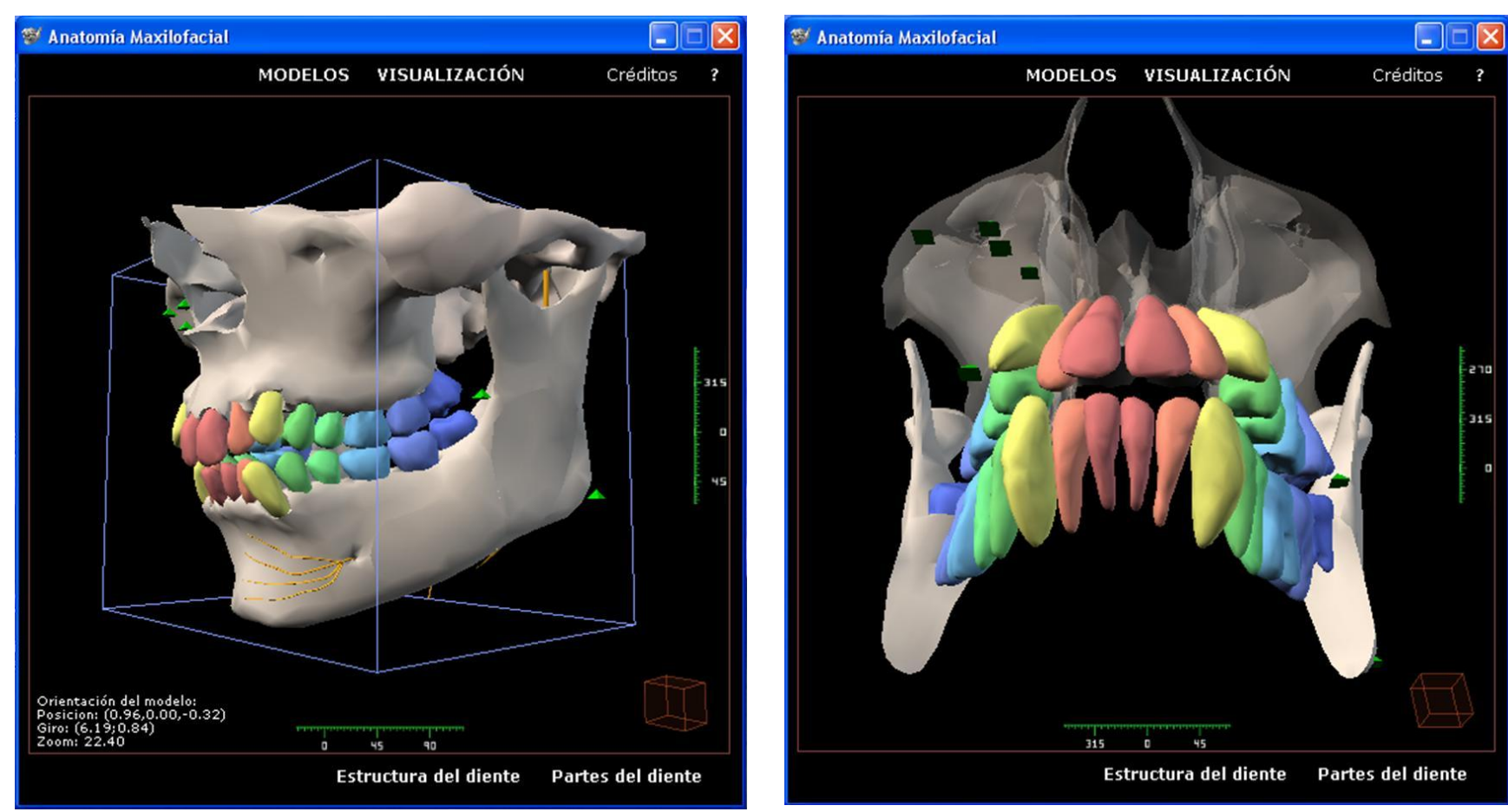

Figura 25.- Visión tridimensional de las dos arcadas dentaria, enclavadas en los maxilares. Los diferentes colores identifican cada tipo de diente.

En el diente podemos diferenciar estructuralmente unos tejidos duros, mineralizados, con un elevado contenido de cristales de hidroxiapatita (esmalte, dentina y cemento), (Figuras 26, 27 y 28) y otros blandos (pulpa dental):

El esmalte: de gran dureza (mineralización del 95\%) y por tanto fragilidad, es un tejido incoloro transparente de naturaleza cristalina que, microscópicamente, presenta una distribución muy ordenada (prismas del esmalte), con unas líneas parduscas de menor calcificación (Estrías de Retzius) que resultan del crecimiento incremental de toda esta estructura adamantina. En 
los dientes no erupcionados o de reciente erupción, está cubierto por una capa de unas 100 micras de espesor (cutícula dentis o membrana de Nasmyth).

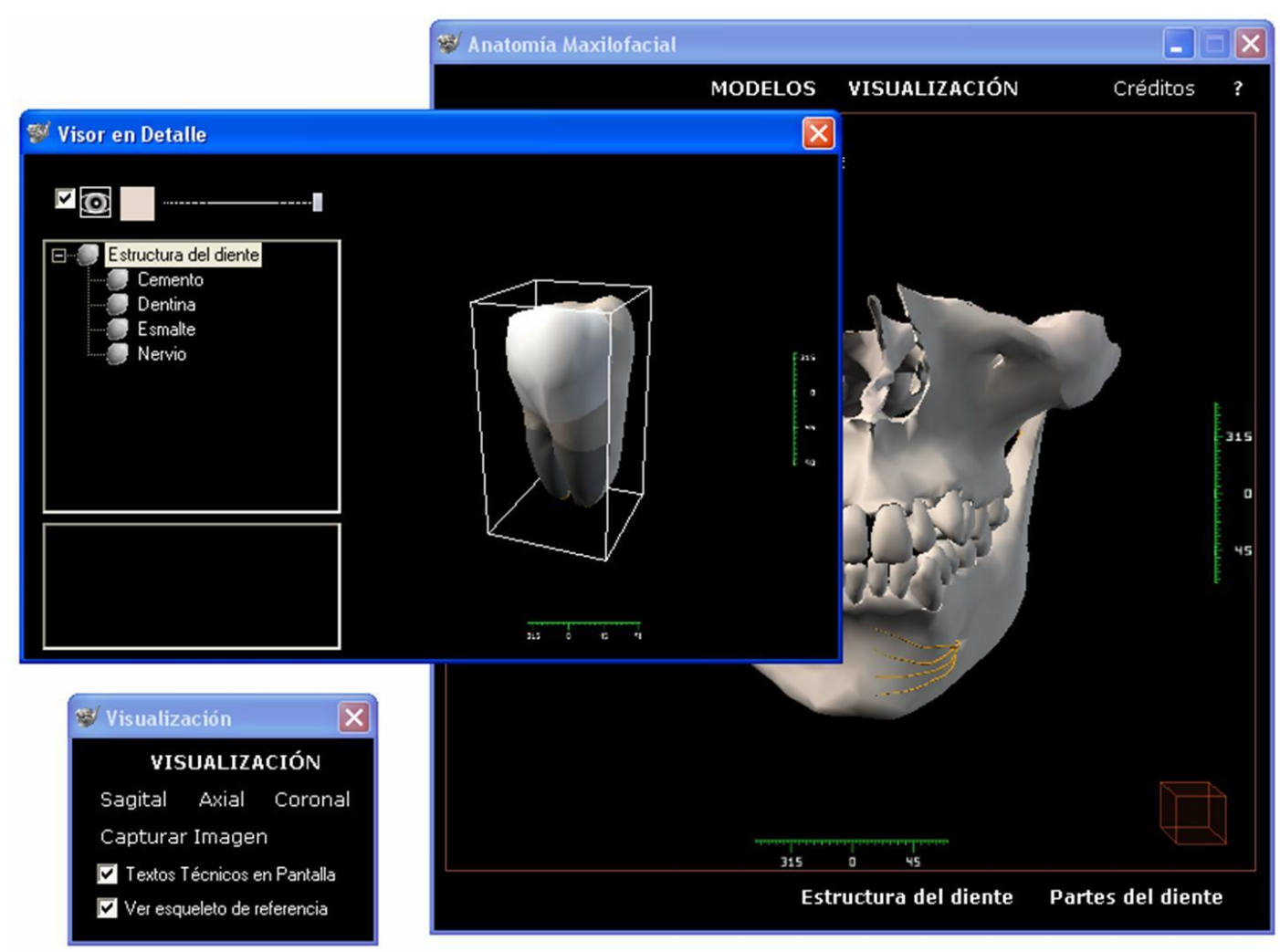

Figura 26.- Activación de la pantalla -Visor en detalle- para el análisis morfológico de una pieza dentaria con sus diferentes estructuras en un árbol desplegable.

La dentina está formada por la actividad odontoblástica, es un tejido de color blanco amarillento, acelular y sensible (por la presencia de fibras amielínicas), menos duro que el esmalte pero más elástico por su mayor porcentaje orgánico (30\% de agua y, fundamentalmente, colágeno). Está constituida por los túbulos o conductillos dentarios en los que discurren las fibras de Tomes (prolongaciones citoplasmáticas de los odontoblastos de la pulpa) y las fibras amielínicas, todo ello rodeado de la sustancia fundamental.

El cemento está en íntima relación con las paredes alveolares, es menos duro (mineralización del $50 \%$ ) y no sensible. Es la única capa en la que 
distinguimos células (cementoblastos) de los tejidos duros del diente. En su sustancia fundamental, se incorporan fibras intrínsecas (cementoblásticas) y otras extrínsecas o perforantes (de origen periodontal).

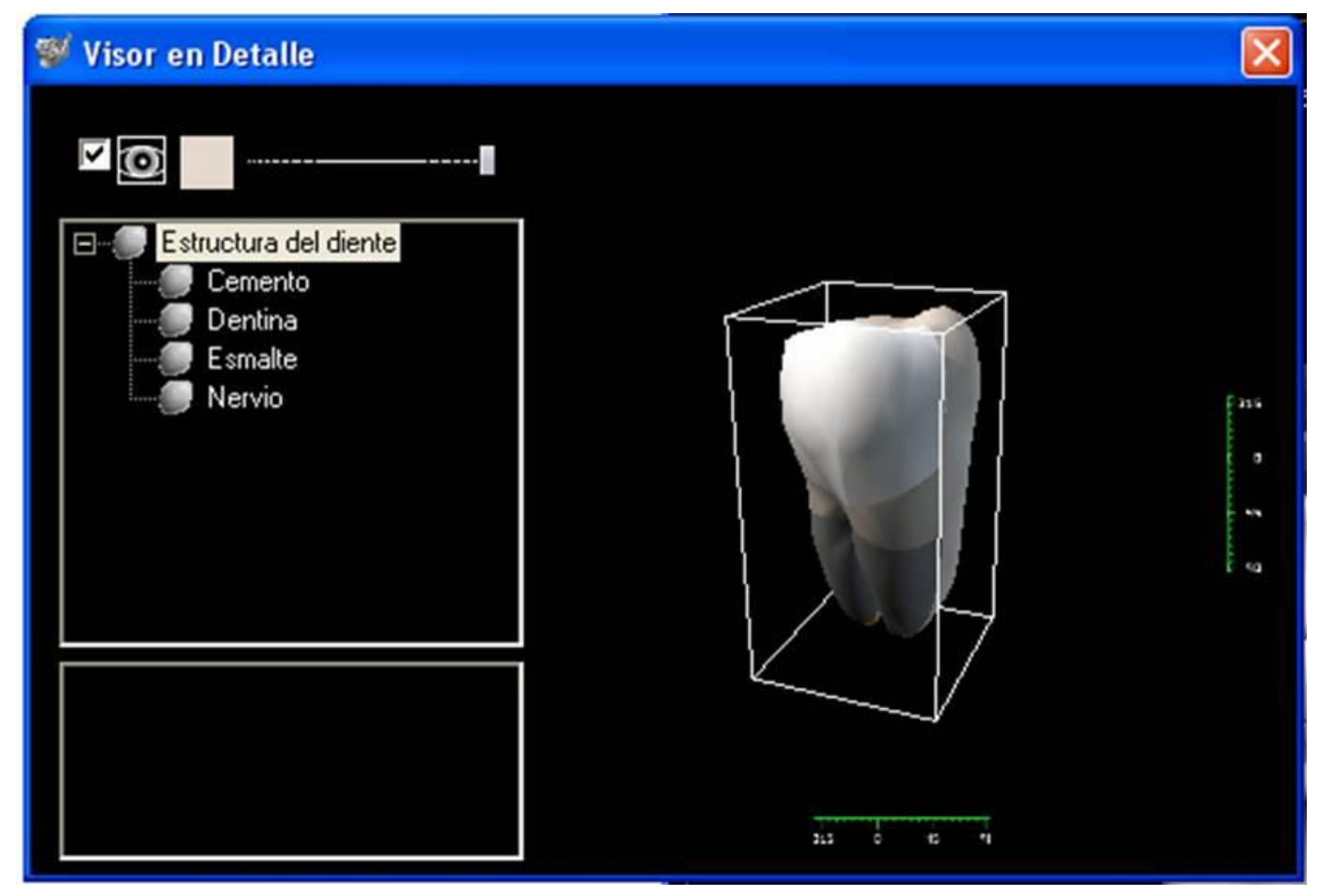

Figura 27.- Visión de la pantalla para la valoración más detallada de una pieza dentaria con sus diferentes estructuras en un árbol desplegable.

La pulpa constituye el tejido conectivo, blando y muy sensible, formado por odontoblastos, fibroblastos, histiocitos, macrófagos y células mesenquimales indiferenciadas, además de una sustancia fundamental intercelular con fibras colágenas y reticulares, vasos y nervios. Sus funciones son la formación y reparación de la dentina por los odontoblastos, la nutrición vascular y la inervación dentaria. 


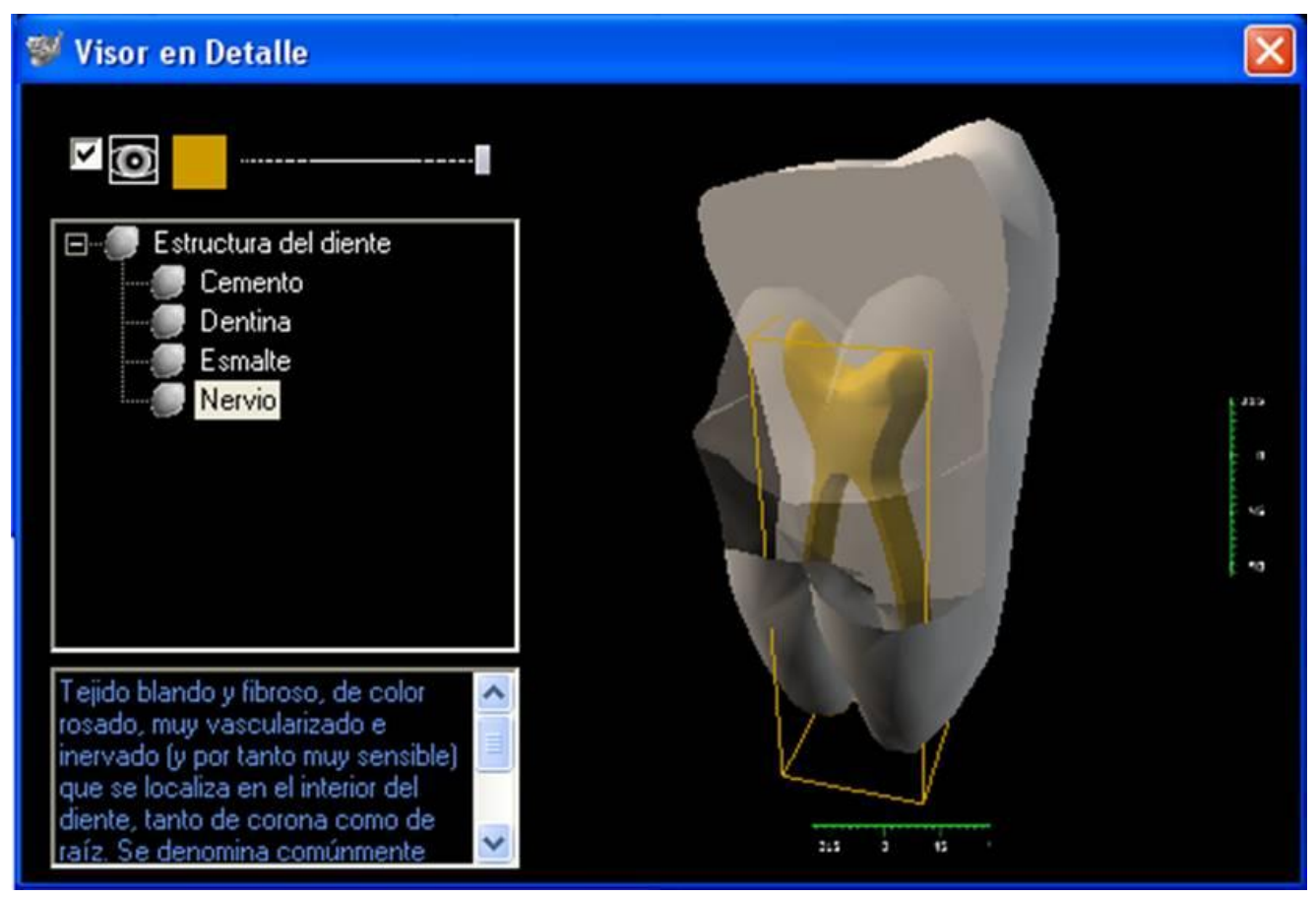

Figura 28.- Activación de la estructura nerviosa del diente, dentro del visor anatómico detallado del diente. Por transparencia se permite ver las diferentes capas envolventes.

Morfológicamente podemos diferenciar en los dientes, la corona, la línea cervical y la raíz (Figura 29).

La corona es la parte visible del diente por no estar incluida en los huesos maxilares, constituida por esmalte y dentina, y de forma variable según el diente de que se trate.

La línea cervical, unión cemento-adamantina o cuello del diente: línea curva irregular que separa el esmalte coronario del cemento radicular. 


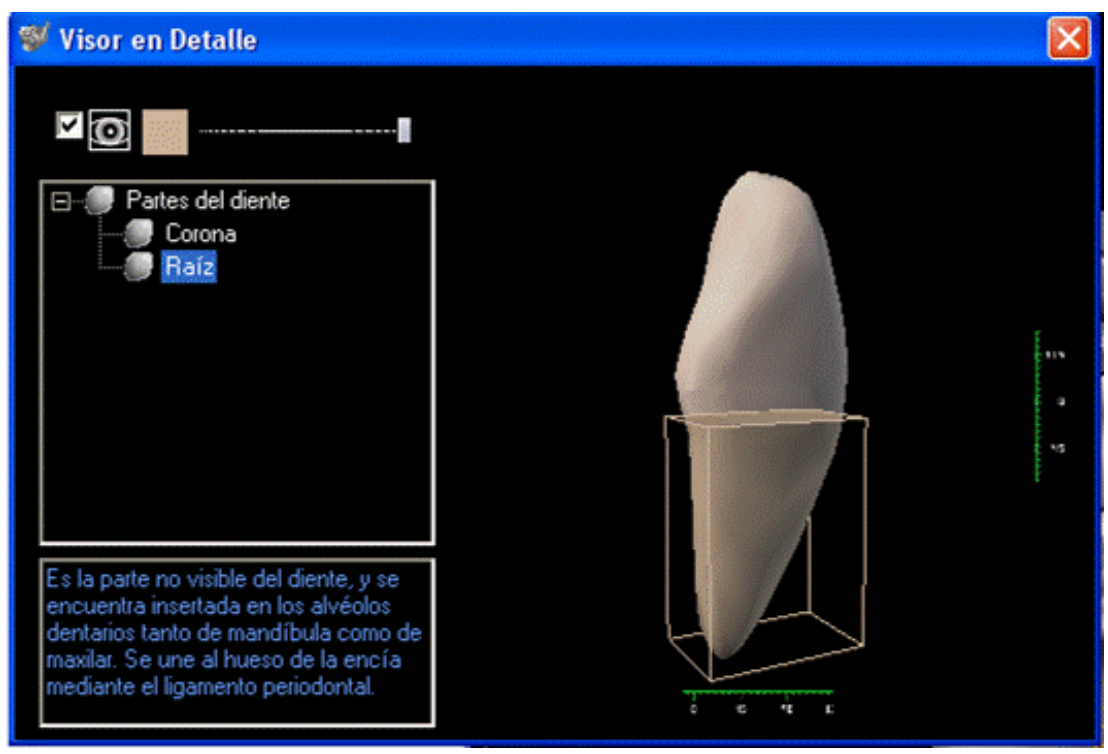

Figura 29.- Valoración morfológica de las diferentes partes del diente (corona y raíz), sobre un modelo 3D dentro del Visor en detalle del procedimiento informático

La porción radicular es única o independizada en varias porciones o raíces en los dientes multirradiculares, es aquella parte del diente incluida en los huesos maxilares. Su porción más distal recibe el nombre de ápice radicular, y está formada por cemento y la parte más apical de la dentina.

La cavidad pulpar se sitúa en el interior de la corona (cámara pulpar) y de la porción radicular (conductos radiculares) y que histológicamente se corresponde con la pulpa.

Los dientes de un individuo, debido a su relación y vinculación entre sí, conforman una unidad funcional y morfológica en la que podemos diferenciar una arcada dentaria superior, formada por los dientes superiores albergados en los maxilares superiores, y otra inferior, formada a su vez por los dientes inferiores albergados en el maxilar inferior. 
Como características comunes de la dentición humana podemos citar que todas las superficies dentarias son redondeadas, la no coincidencia en forma ni tamaño de los dientes homólogos de arcos dentarios antagónicos (anisognatismo), su asimetría y su convergencia palatal o lingual, incisal u oclusal, y cervical.

La dentición permanente consta de cuatro grupos dentarios (incisivo, canino, premolar y molar). Mientras que en la dentición temporal falta el grupo premolar.

\section{Grupo dentario incisivo (Figura 30)}

Formado por ocho piezas dentarias (dos por hemiarcada) con la corona aplanada (dientes haplodontos), situados en la parte más anterior de los arcos dentarios y cuya función es cortar los alimentos.

Incisivos permanentes:

Características comunes:

- Corona:

Borde incisal con tres mamelones.

Superficie vestibular convexa con dos surcos que parten de los mamelones.

Superficie lingual o palatina convexa en su tercio cervical (cíngulo) y cóncava en sus dos tercios incisales, limitada lateralmente por los rebordes marginales.

- Línea cervical:

Con un trayecto cóncavo hacia incisal en las superficies vestibular y lingual o palatina; en las superficies mesial y distal es alternativamente cóncava, convexa y cóncava. 
- Raíz:

De forma cónica. Son dientes unirradiculares.

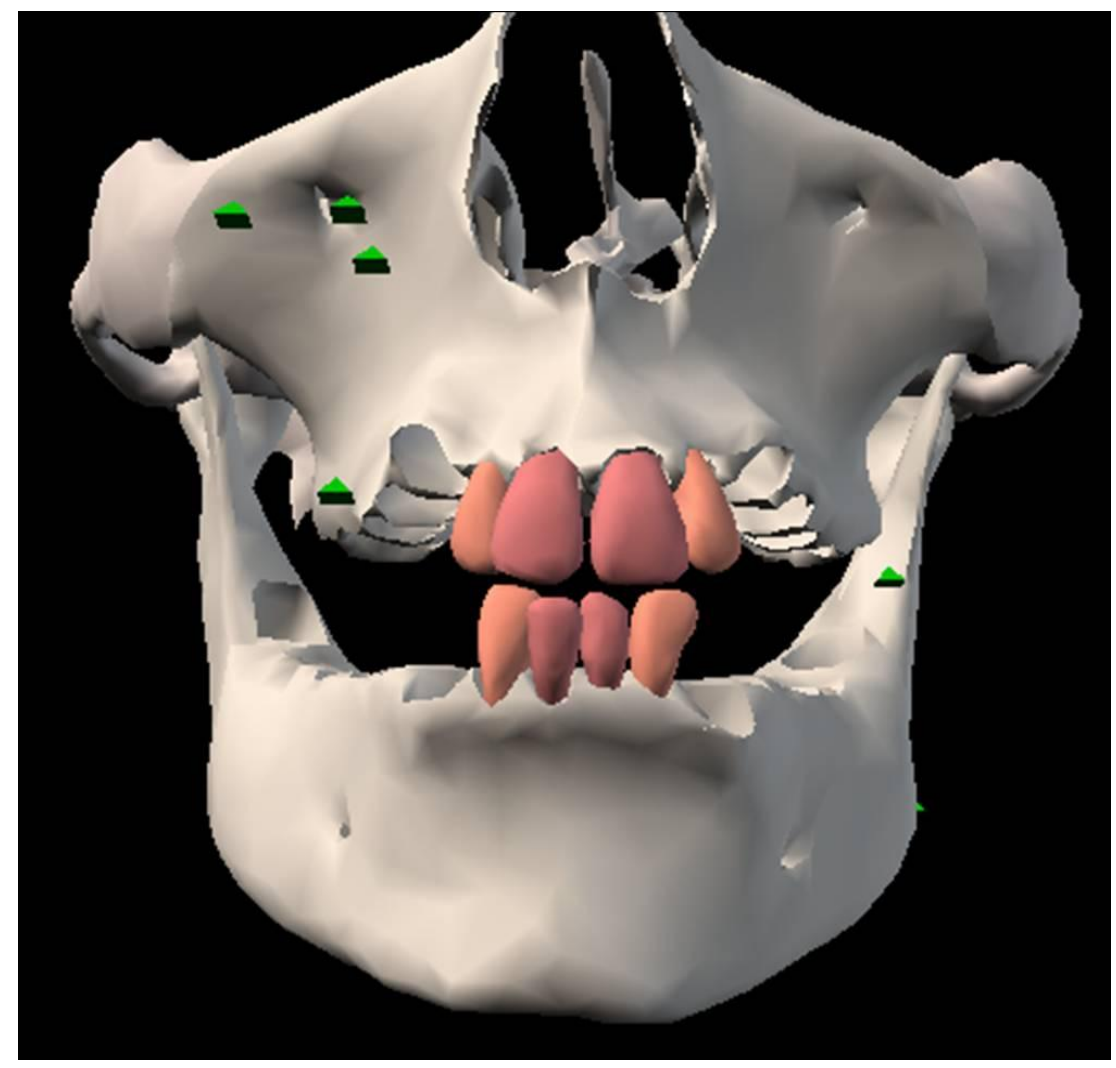

Figura 30.- Representación tridimensional del grupo dentario incisivo

Características diferenciales:

- Incisivo central superior:

El ángulo mesio-incisal es recto, mientras que el disto-incisal es redondeado.

Bajo el cíngulo se encuentra una concavidad: la fosita lingual.

La raíz es proporcionalmente corta por su relación con el suelo de las fosas nasales. 
- Incisivo lateral superior:

Los ángulos mesial y distal son redondeados, y los mamelones están poco diferenciados.

Ocasionalmente presentan una fisura central en el cíngulo denominada "agujero ciego".

La raíz es proporcionalmente larga y, en bastantes ocasiones, el ápice se incurva hacia distal.

- Primer incisivo inferior:

Es el diente más pequeño de la dentición permanente.

Los ángulos que limitan su borde incisal son rectos.

La raíz es larga y estrecha.

- Segundo incisivo inferior:

Ligeramente mayor que el anterior, su raíz está ligeramente torsionada con relación a la corona.

Incisivos temporales:

Características comunes:

- Corona:

Mamelón central menor que los mamelones laterales.

Diámetro mesio-distal mayor que el cérvico-incisal.

- Línea cervical:

Sus inclinaciones son menos pronunciadas que las de los incisivos permanentes. 
- Raíz:

Con una desviación lingual o palatina de los dos tercios cervicales de la misma con relación a la corona.

\section{Grupo dentario canino (Figura 31)}

Formado por cuatro piezas dentarias (un diente por hemiarcada) tanto temporales como permanentes, con una morfología muy favorable para cortar alimentos, y cuatro lóbulos de desarrollo, estando el lingual o palatino menos evolucionado.

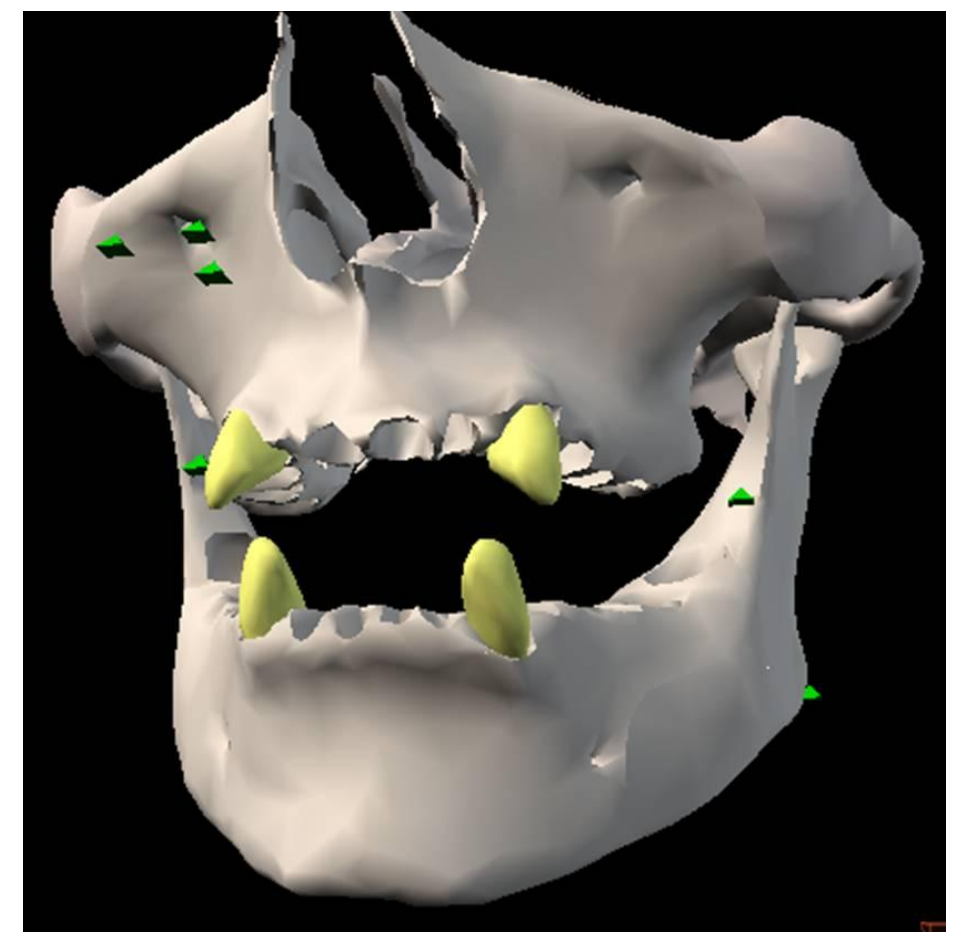

Figura 31.- Representación tridimensional del grupo dentario canino

- Caninos permanentes:

$>$ Características comunes:

- Corona: 
Cúspide puntiaguda en el borde incisal cuya vertiente mesial es más horizontal que la distal.

Superficie vestibular convexa divida en dos facetas por una cresta vertical y media.

Superficie lingual o palatina dividida por una cresta que va desde la cúspide hasta el cíngulo en dos fosas limitadas lateralmente por los rebordes marginales.

Superficies mesial y distal triangulares cuyos vértices forman un continuo con las vertientes del borde incisal.

- Línea cervical:

En la superficie vestibular es cóncava hacia incisal, en la lingual o palatina es cóncava o recta y en la mesial y distal cóncava-convexacóncava.

- Raíz:

Son dientes unirradiculares con una raíz robusta con surcos longitudinales mesial y distal, y el ápice normalmente desviado hacia vestibular y mesial.

Características diferenciales:

El canino inferior es menos robusto y con los detalles morfológicos menos marcados que en el superior.

- Caninos temporales:

Características comunes:

- Corona:

El mayor diámetro mesiodistal hace que sea más bulbosa. 
- Línea cervical:

Sus inclinaciones son menos pronunciadas.

- Raíz:

En los superiores los dos tercios cervicales tienen una desviación palatina con respecto a la corona mientras que las raíces de los inferiores tienen la misma dirección que la corona.

\section{Grupo dentario premolar (Figura 32)}

Únicamente presente en la dentición permanente, está formado por ocho piezas dentarias (dos por hemiarcada) con cuatro lóbulos de desarrollo (tres vestibulares y uno lingual, salvo en la variedad tricuspídea del segundo premolar inferior que tiene cinco: tres vestibulares y dos linguales), y cuya función es triturar los alimentos.

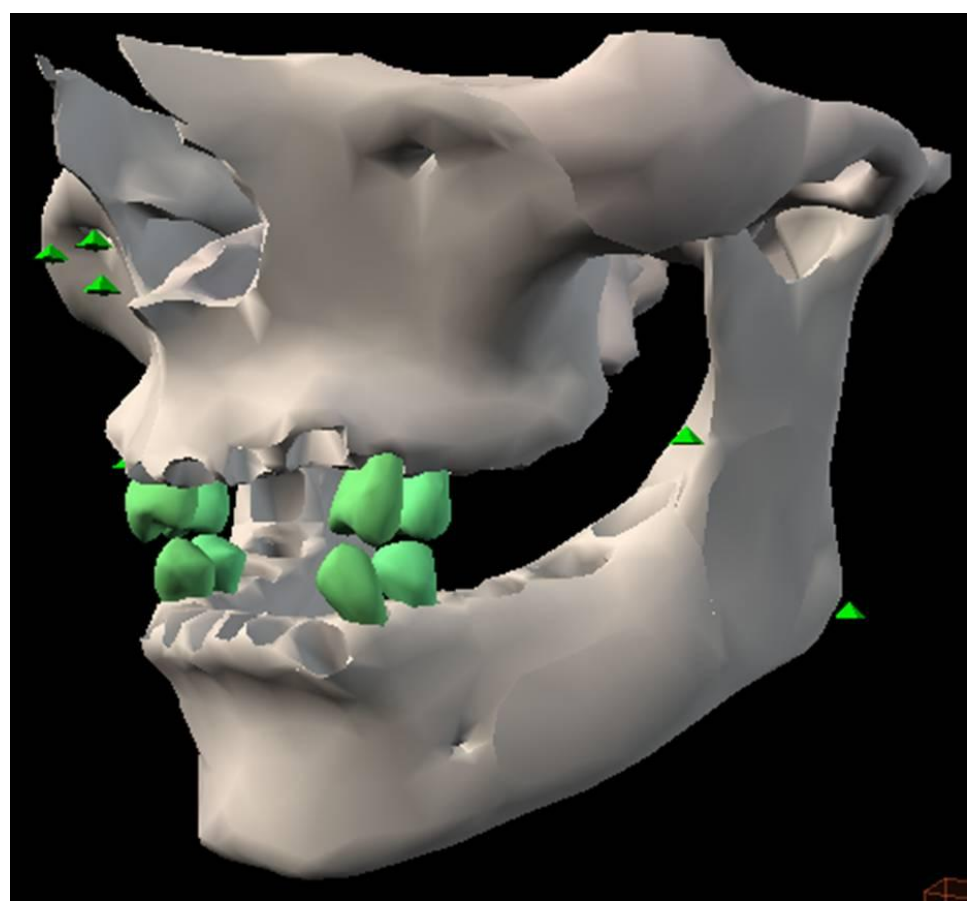

Figura 32.- Representación tridimensional del grupo dentario premolar 
- Características comunes:

\section{Corona:}

Se caracteriza por presentar dos cúspides (grupo dentario bicuspídeo), una vestibular o bucal y otra lingual o palatina, separadas por una surco central de dirección mesiodistal.

La superficie vestibular es mayor y más larga que la lingual o palatina.

\section{Línea cervical:}

En general, en la superficie vestibular y lingual o palatina se dispone cóncava hacia oclusal, mientras que en mesial o distal es convexa o recta.

Raíz:

Se trata de piezas uni o birradiculares.

Es el grupo dentario en el que los ápices dentarios presentan una menor incurvación.

- Características diferenciales:

Primer premolar superior:

$\mathrm{Su}$ cúspide vestibular trilobular conforma una superficie oclusal pentagonal de aspecto asimétrico por la posición más mesial de la cúspide palatina.

La superficie vestibular está dividida en dos facetas convexas por una cresta que va desde el vértice de la cúspide hasta la línea cervical. En las superficies mesial y distal a nivel del punto en el que convergen las dos vertientes de su borde oclusal parte un surco longitudinal hacia la línea cervical pero sin llegar a alcanzarla. 
Suele ser birradicular (una raíz vestibular y otra palatina) y cuando es unirradicular presenta un surco longitudinal en las porciones mesial y distal de la raíz.

Segundo premolar superior:

Más corto y agudo que el primero, las cúspides vestibular y palatina tienen una disposición simétrica.

En la mayoría de los casos es unirradicular con el surco longitudinal situado en mesial y distal.

Primer premolar inferior:

La cúspide lingual está poco desarrollada y apenas interviene en la oclusión dentaria.

La superficie lingual es atravesada por un surco longitudinal mesiodistal.

Es unirradicular, presentando el surco longitudinal en las superficies laterales.

Segundo premolar inferior:

Su corona es más roma.

Ocasionalmente es tricuspídeo: una cúspide vestibular y dos linguales, separadas por un surco en $\mathrm{Y}$, con dos fosas principales.

Es unirradicular, presentando el surco longitudinal en las superficies laterales.

\section{Grupo dentario molar (Figura 33)}

Formado por diferente número de piezas en la dentición temporal (ocho piezas, dos por hemiarcada) que en la permanente (doce, tres por hemiarcada), que englobamos, por su mayor desarrollo y sus anchas coronas, dentro de los 
dientes lofodontos, cuya función es la trituración de los alimentos para formar el bolo alimenticio.

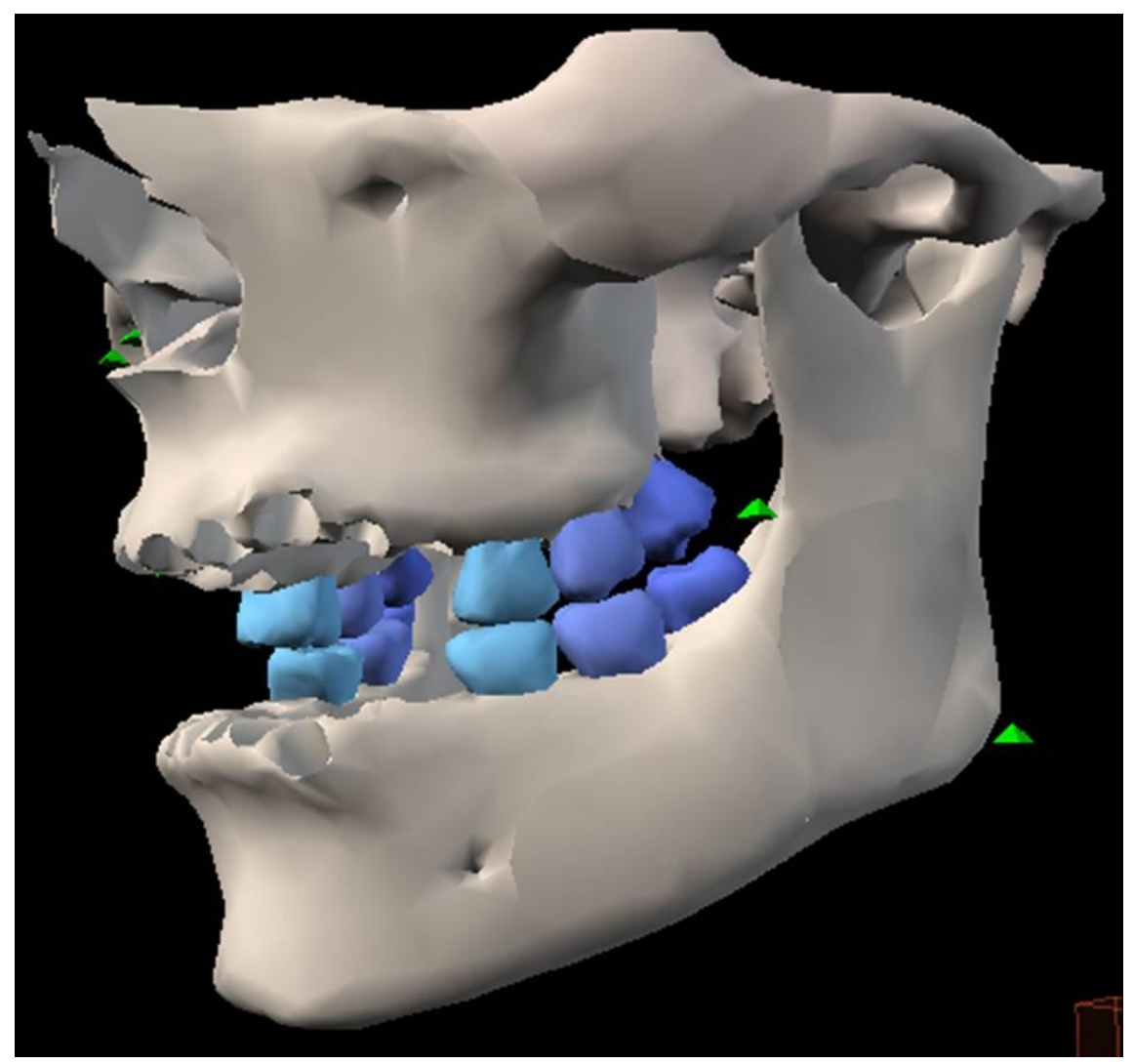

Figura 33.- Representación tridimensional del grupo dentario molar permanente

El primer molar inferior permanente y el segundo molar inferior deciduo tienen cinco lóbulos de desarrollo. Los demás tienen generalmente cuatro, aunque el segundo molar superior permanente y el primer molar superior deciduo pueden presentar sólo tres lóbulos (trigonodontes), y los terceros molares, que son muy variables, pueden tener tres, cuatro o cinco lóbulos. 
- Molares permanentes:

Características comunes:

- Corona:

La superficie oclusal es multicuspídea: está formada por cuatro o más cúspides separadas por surcos y fosas.

- Línea cervical:

En vestibular es cóncava, en lingual o palatina es cóncava, convexa y cóncava alternativamente (o cóncava toda ella), y en mesial o distal es ligeramente cóncava o recta.

- Raíz:

Los molares superiores son generalmente trirradiculares y los inferiores birradiculares.

Características diferenciales:

- Primer molar superior:

Su superficie oclusal tiene cuatro cúspides funcionales, de las cuales la mesiopalatina es la de mayor tamaño y la distopalatina la más pequeña, y una afuncional conocida como tubérculo de Carabelli situado mesiooclusalmente en la superficie palatina.

La superficie vestibular presenta en la separación entre las cúspides vestibulares un surco longitudinal hasta la mitad de su superficie.

La superficie palatina presenta igualmente un surco longitudinal de separación de las cúspides palatinas ligeramente desplazado hacia distal. 
Es un diente trirradicular (palatina, mesiovestibular y distovestibular) con los ápices frecuentemente incurvados.

- Segundo molar superior:

La cúspide distopalatina es de menor tamaño o a veces no existe, teniendo entonces un aspecto tricuspídeo.

Es trirradicular aunque con frecuencia se fusionan dos de sus tres raíces.

- Tercer molar superior:

Es un diente irregular en forma (generalmente tricuspídea), implantación (suele estar incluido) y raíces que suelen estar fusionadas.

- Primer molar inferior:

Es pentacuspídeo, con tres cúspides vestibulares (la distal es la menos desarrollada) y dos linguales.

La superficie vestibular tiene dos surcos longitudinales incompletos (uno en la lingual) que parten de la confluencia de las cúspides.

Es birradicular con una raíz mesial y otra distal.

- Segundo molar inferior:

Tiene cuatro cúspides (dos vestibulares y dos linguales) separadas por dos surcos en cruz.

Tanto la superficie vestibular como la lingual presentan un surco longitudinal incompleto que parte de la separación de las dos cúspides.

Es un diente birradicular cuyas raíces se fusionan con frecuencia y con incurvación apical frecuente. 
- Tercer molar inferior:

Diente irregular de corona bulbosa, penta o tetracuspídeo, que frecuentemente está incluido.

Sus raíces, en número y forma variable, se encuentran generalmente fusionadas.

- Molares temporales:

Características comunes:

Son dientes multicuspídeos y multirradiculares, los segundos con un mayor desarrollo morfológico que los primeros, cuya forma y disposición no se corresponde con los permanentes y cuyas raíces tienen una mayor divergencia por albergar entre ellas los gérmenes de los premolares permanentes.

Características diferenciales:

- Primer molar superior:

Generalmente tricuspídeo (dos vestibulares y una palatina más desarrollada) separadas por un surco con forma de $\mathrm{T}$.

En la superficie vestibular, en situación cérvico-mesial, se encuentra el tubérculo de Zuckerkandl.

Es trirradicular aunque con gran tendencia a la fusión de la raíz palatina con la distovestibular.

- Segundo molar superior:

Es tetracuspídeo (dos vestibulares y dos linguales) de las que la más pequeña es la disto-lingual.

Ocasionalmente presenta el tubérculo de Carabelli. 
Es trirradicular con tendencia a la fusión.

- Primer molar inferior:

Superficie oclusal ovoidea con cuatro cúspides, dos vestibulares y dos linguales, separadas por surcos cruzados.

Birradicular (una mesial y otra distal), muy divergentes para albergar el germen del primer premolar inferior permanente.

- Segundo molar inferior:

Morfológicamente muy similar al primer molar inferior permanente.

\section{Los arcos dentarios}

Los dientes, tanto los superiores como los inferiores, deben estar correctamente alineados y sin espacio entre ellos, disponiéndose dentro de los alvéolos de los maxilares en forma de curva abierta hacia atrás, constituyendo dos arcos, superior e inferior, que actúan como una unidad en el desempeño de las funciones propias del aparato dentario (masticación, articulación de la palabra, estética y mímica facial, etc.).

- Partes del arco dentario:

El plano medio sagital divide tanto el arco dentario superior como el inferior en dos hemiarcadas, derecha e izquierda.

Podemos diferenciar un segmento anterior de canino a canino formado por los dientes anteriores y dos segmentos posteriores de primer premolar hasta el último molar.

También podemos distinguir una parte coronaria formada por las coronas dentales, parte que es visible dentro de la boca, y una parte radicular formada por las porciones radiculares implantadas en los alvéolos dentarios y cubiertas por la mucosa gingival. 
Al igual que los dientes, los arcos poseen una superficie anterior y convexa (vestibular), otra posterior y cóncava (palatina en el arco superior y lingual en el inferior), un borde incisal en el segmento anterior y una superficie oclusal en los sectores posteriores.

- Características generales:

Cada diente debe estar correctamente alineado en la curva, el nivel de los bordes incisales y caras oclusales será homogéneo, su tamaño debe estar en consonancia con el de las bases óseas y el conjunto de la cara, y no deben existir espacios edéntulos.

Características de los arcos dentarios permanentes:

La forma de la arcada dental está en relación con su base ósea: los braquicefálicos tendrán una arcada ancha, mientras que la de los dolicocéfalos será estrecha.

La disposición de los dientes en los dos segmentos del arco es la responsable de la forma del arco dentario: superior ovoidea e inferior parabólica.

El tamaño de los dientes y los maxilares debe estar en una relación armónica. El diámetro transversal de ambos arcos es mayor que el anteroposterior, diferencia más acusada en el arco inferior. El diámetro anteroposterior del arco superior es mayor que el del inferior, al contrario que el transversal que es mayor en el inferior, a pesar de lo cual, y debido a su inclinación, los dientes superiores sobresalen cubriendo parte de cara vestibular de los inferiores. La longitud del arco es la suma de los diámetros mesiodistales de los dientes y debe estar en relación con la longitud de las bases óseas (discrepancia oseodentaria). 
En general todos los dientes se inclinan hacia atrás, arriba y adentro, salvo los incisivos inferiores cuyos ápices lo hacen hacia lingual y las coronas hacia vestibular.

Las superficies oclusales tienen cierta curvatura (curvas de compensación), la superior convexa y la inferior cóncava. La curva de Spee se dibuja en el plano sagital al unir con una línea imaginaria las cúspides y las crestas marginales de los molares con los bordes incisales. También uniendo las superficies oclusales de los molares pero en el plano transversal se forma la denominada curva de Wilson.

Características de los arcos dentarios temporales:

Tienen una forma ovalada, tanto el superior como el inferior.

Son de menor tamaño que los permanentes, al igual que lo son los dientes temporales. El arco superior es más grande que el inferior en todos los diámetros.

Los arcos presentan diastemas por el crecimiento maxilar, necesarios para el cambio de dentición.

Las superficies oclusales de ambos arcos temporales dibujan prácticamente un plano.

Características de los arcos de transición:

Presentan todo tipo de discrepancias tanto diastemas como apiñamientos.

- Relaciones interproximales:

Cada diente establece una relación de contacto puntual con el diente anterior y posterior en la arcada a través de sus caras mesial y distal salvo, lógicamente, en el caso de los incisivos centrales y de los cordales. Se establecen en la zona más sobresaliente de las caras proximales y debido al 
desgaste de las coronas se sitúan cada vez más próximos a las superficies oclusales.

Bajo el punto de contacto queda un espacio triangular denominado espacio interdental que está ocupado por la papila interdental. Por encima queda un espacio muy estrecho: el surco interdental.

Los puntos de contacto son un apoyo bilateral de los dientes por los cuales se transmiten las fuerzas oclusales.

- Relaciones de antagonismo:

Son las establecidas entre ambas arcadas superior e inferior en las distintas situaciones funcionales posibles, como la masticación, la deglución, la fonación y el reposo.

Los factores que determinan las posibles relaciones de antagonismo son la posición de los arcos dentarios (con o sin contacto), la actividad muscular (contracción o relajación) y la situación funcional de la mandíbula (estática o dinámica).

Para lograr una correcta texturización de los modelos anatómicos tridimensionales de nuestra Tesis Doctoral es necesario desarrollar coordenadas de textura a través de proyecciones geométricas y desarrollos más complejos mediante la aplicación splines (curvas diferenciables definida en porciones mediante polinomios) y operaciones matemáticas. Los splines nos permiten trabajar tanto en una como en varias dimensiones. Los volúmenes generados en la etapa de modelado de nuestras estructuras anatómicas se reorganizaron en base a las texturas aplicadas. Este proceso de texturización puede variarse dependiendo si son texturas repetitivas, imágenes fotográficas, texturas de iluminación o de detalle, lo que cambiaría las características de un modelo anatómico, que en nuestro trabajo siempre se ha buscado obtener el menor número de archivos para su procesamiento en tiempo real, en ordenadores 
personales con características técnicas elementales; por ello optamos a la utilización de modelos de baja resolución poligonal.

Por tanto, si bien en nuestro programa informático hemos empleado modelos alambritos sencillos para evitar enlentecer la aplicación, sin embargo, queremos mostrar iconográficamente la posibilidad de llevar a cabo modelos anatómicos tridimensionales muy próximos a la realidad (Figura 34), con el consiguiente aumento de su capacidad de tamaño de archivo que dificulta el manejo y la manipulación de la imagen para su valoración con cualquier posición espacial.

Este procedimiento se consigue mediante la reorganización de información, aplicándose por una de las caras y vértices de una estructura anatómica, lo que conlleva a que un mismo vértice y cara puede tener coordenadas separadas por polígonos, permitiendo un mayor aprovechamiento del espacio, y evitar no desperdiciar memoria en espacios vacíos en el modelo alámbrico o de malla.

De este aprovechamiento del espacio depende la división o adición de determinadas mallas, manteniendo una escala uniforme entre elementos del mismo material y en los casos que no se logra, la malla tiene que subdividirse, reordenando el modelo anatómico.

También se pueden aplicar otros elementos para aumentar el realismo del modelo anatómico, como con el falso relieve, que permite aparentar un mayor detalle (Figura 34) mediante una técnica de iluminación en el renderizado en tiempo real, sin modificar la superficie de la malla y el proceso de renderizar la iluminación a la textura, que permite aplicar cálculos de iluminación complejos y ejecutarlos como una textura, reduciendo el procesamiento por iluminación en tiempo real. 


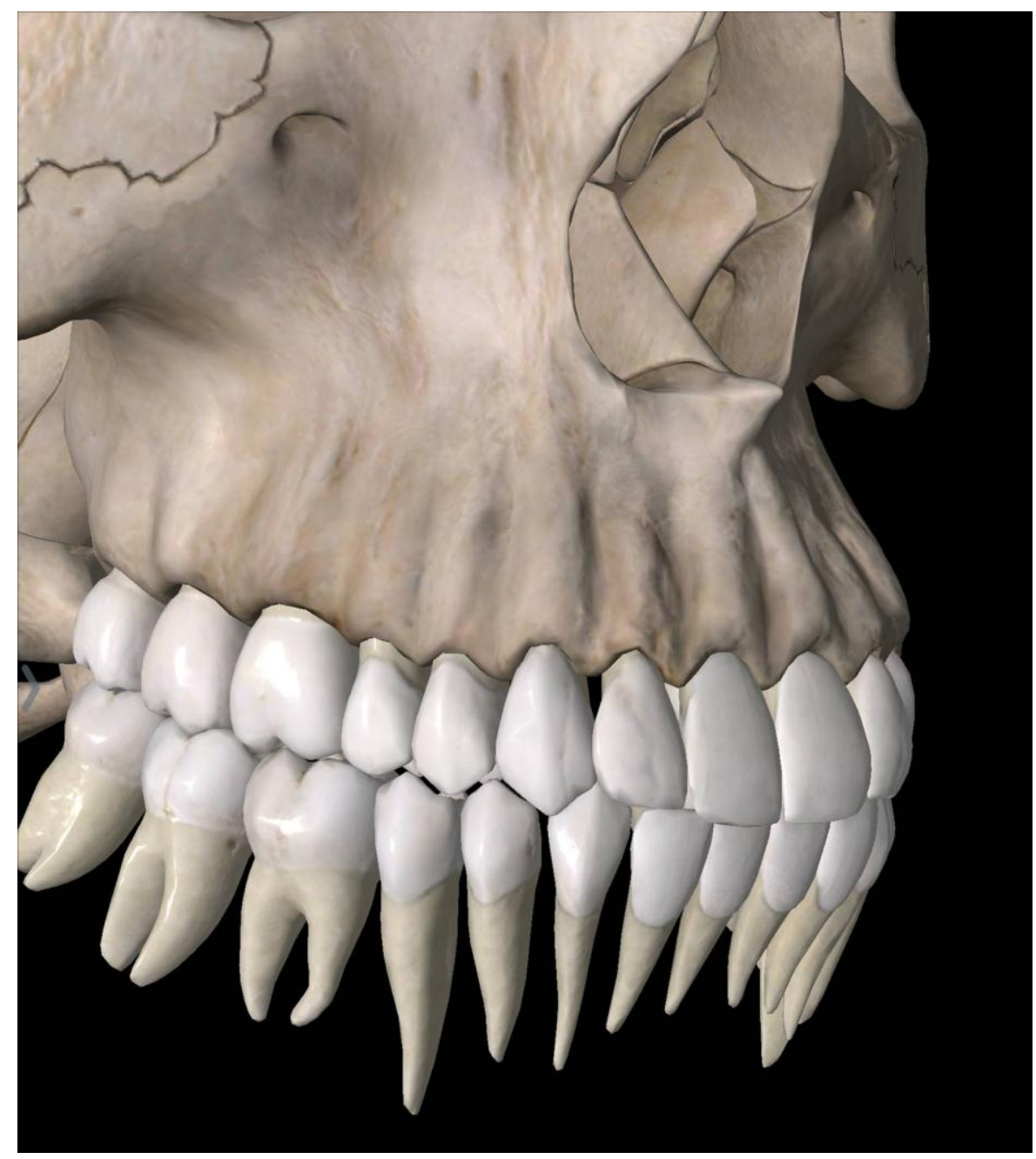

Figura 34.- Visión tridimensional, del aparato dentario con texturización poligonal de alta resolución, que se aproxima más a la realidad anatómica
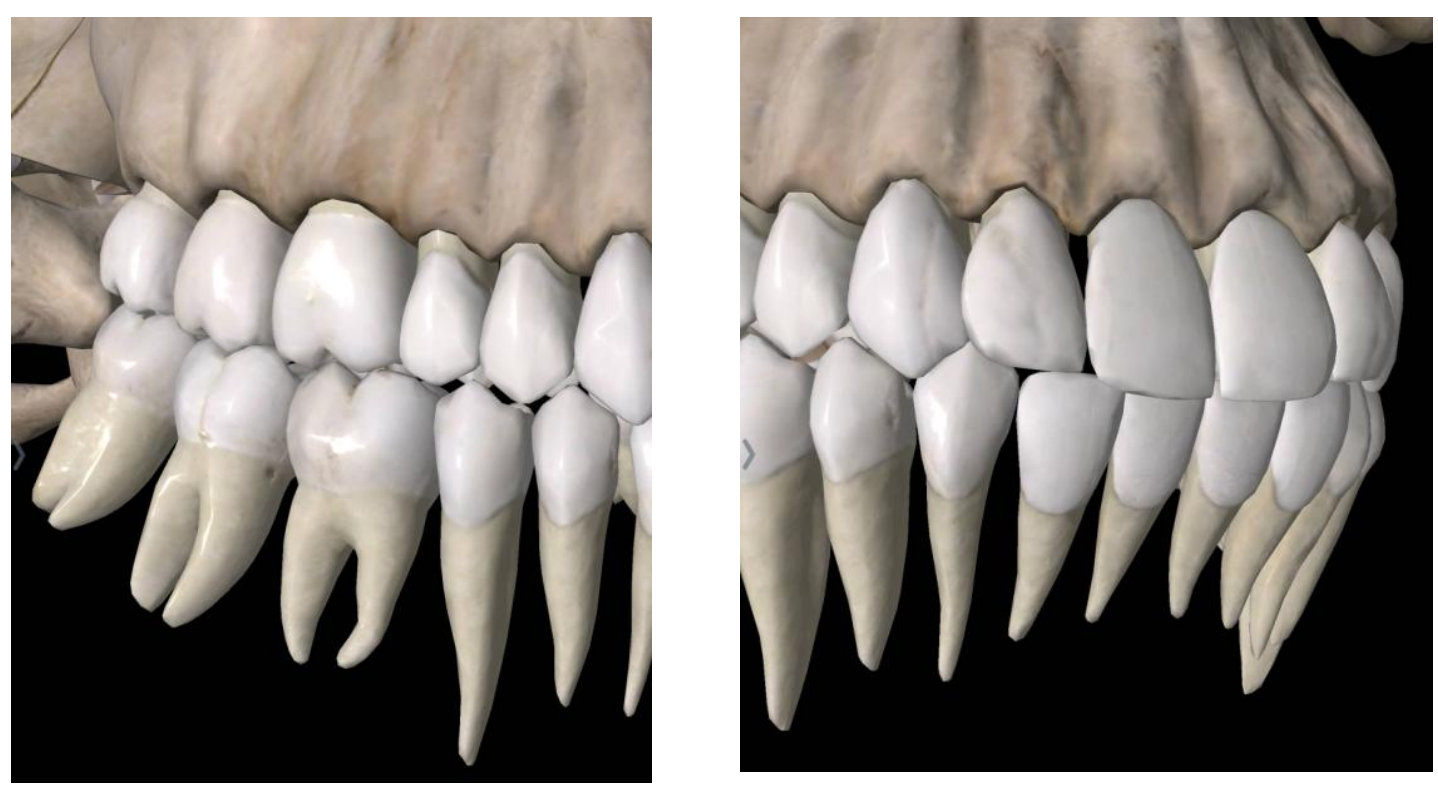
6.4.- Nervio mandibular (V3) (Figuras 35, 36, 37 y 38)
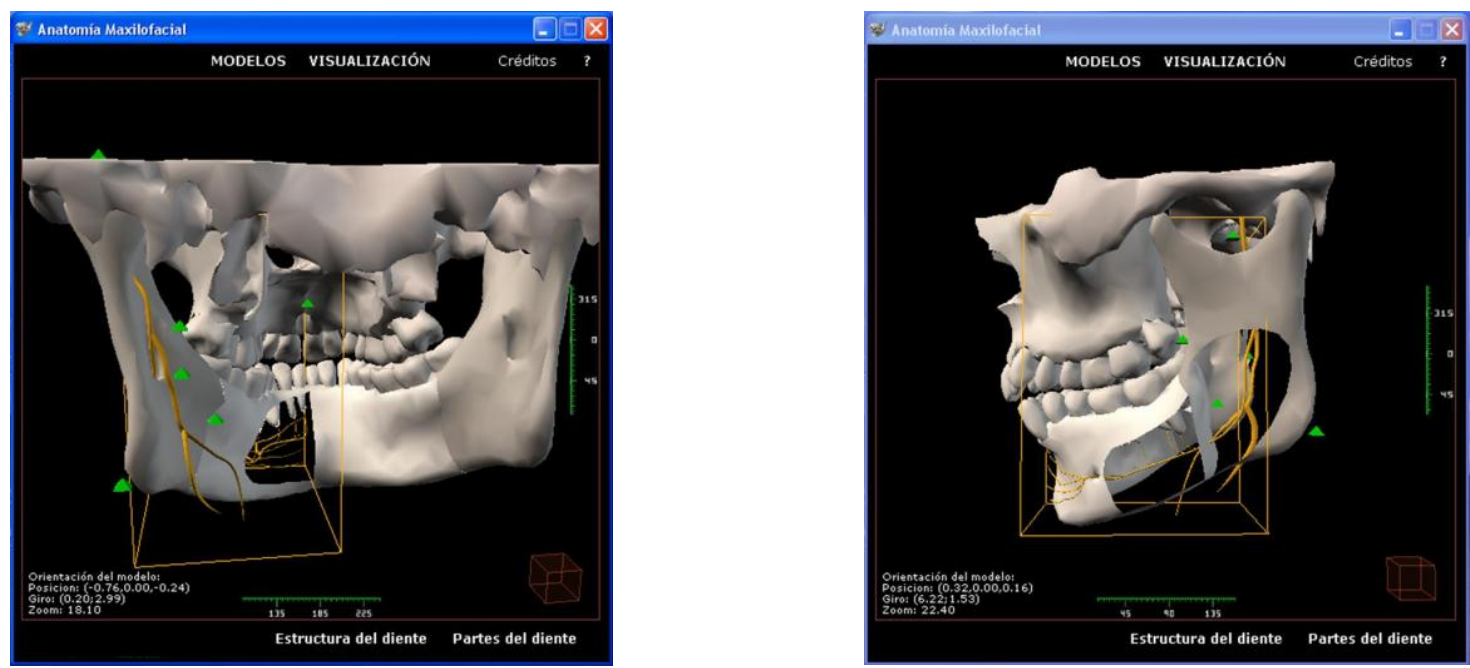

Figura 35.- Visión tridimensional, en diferentes posiciones espaciales, del nervio mandibular con algunas de sus ramas
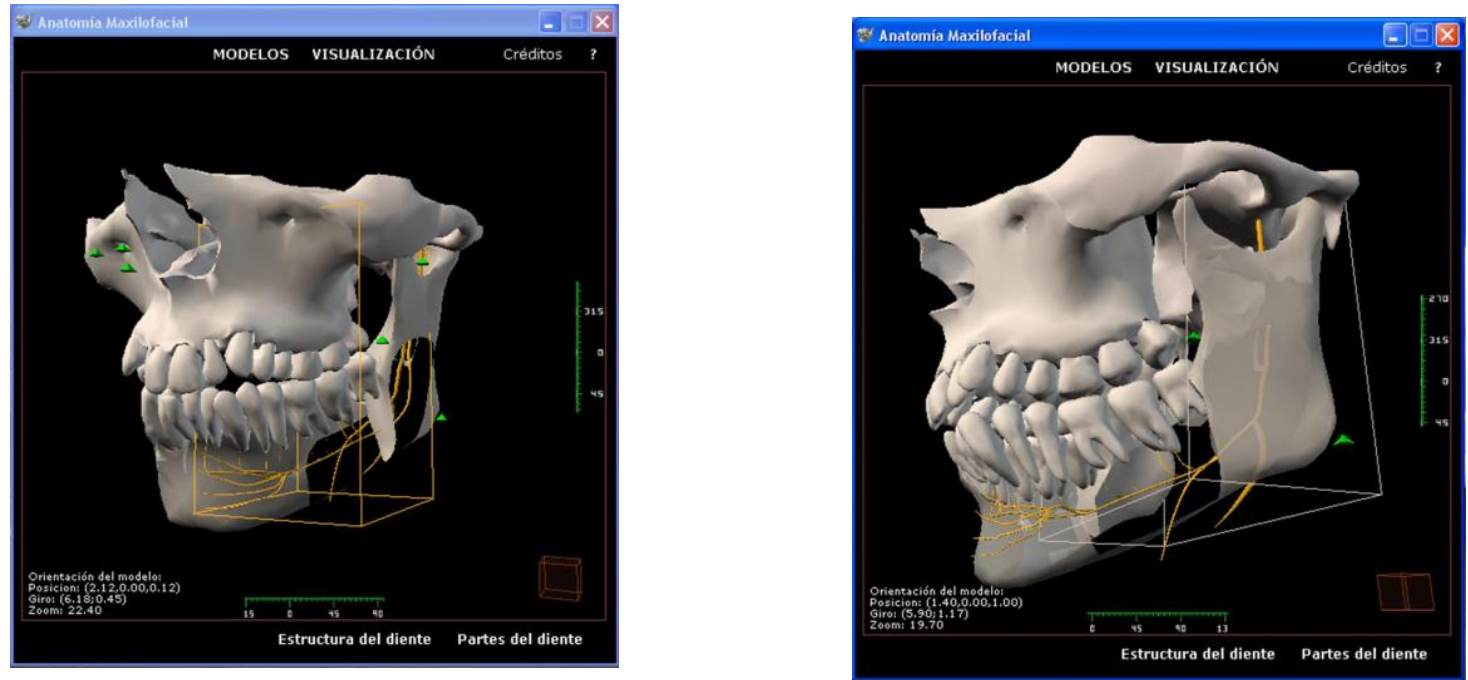

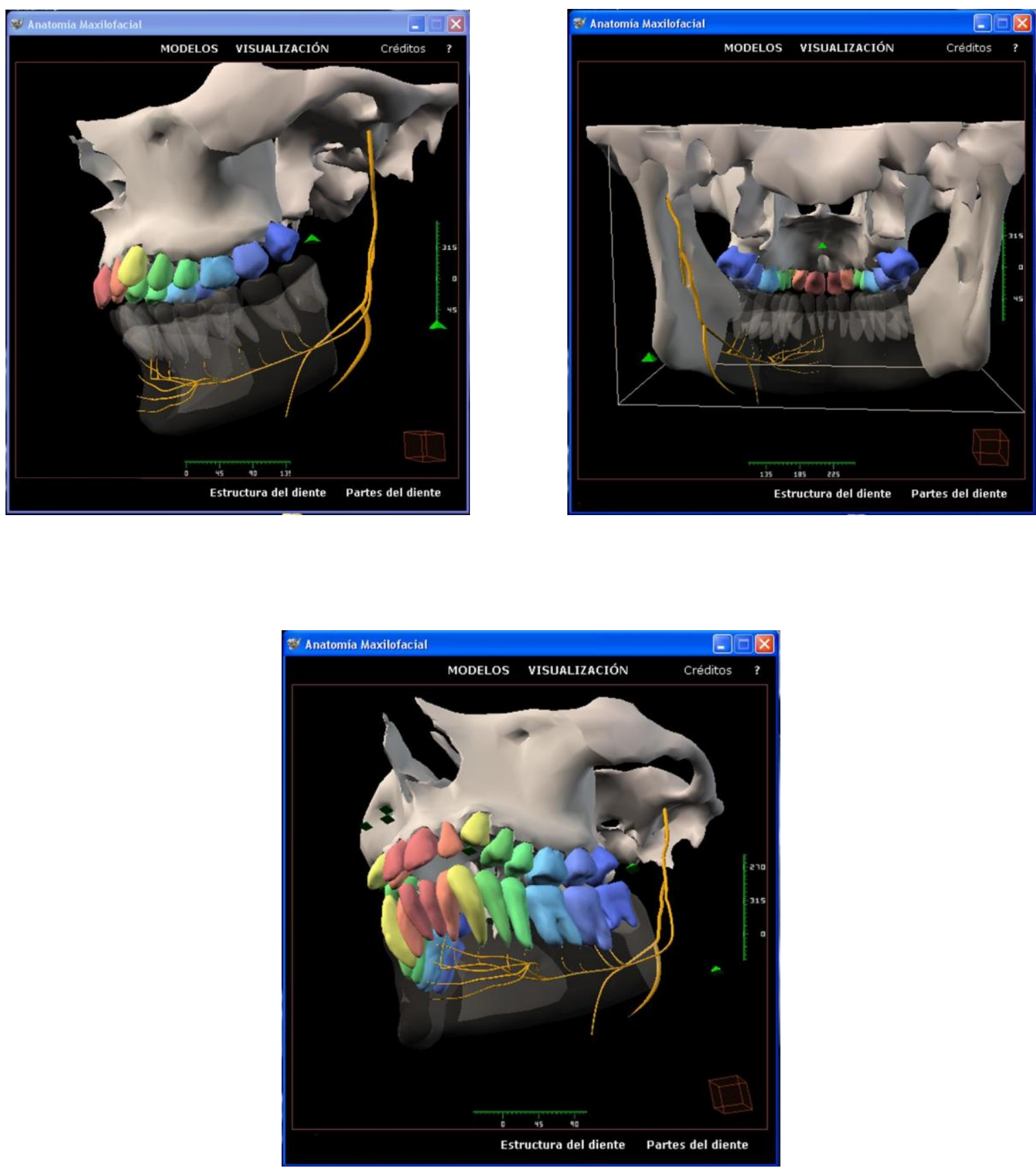

Figura 36.- Visión tridimensional, en diferentes posiciones espaciales, del nervio mandibular con algunas de sus ramas 
Es la más larga de las tres divisiones del trigémino, y la única que tiene un componente motor y sensitivo. La raíz sensitiva se desprende de la parte más externa del ganglio de Gasser; la motora constituye el nervio masticador o mandibular.

En el cavum de Meckel, la raíz motora se sitúa inferior a otras ramas del nervio trigémino V1 y V2, sale de la base del cráneo atravesando el agujero oval sin cruzar el seno cavernoso. En el agujero oval se relaciona con otras estructuras como el nervio petroso superficial menor, las venas emisarias y la arteria accesoria meníngea.

En el compartimento medio de la base del cráneo, por medio de su vaina, el nervio maxilar inferior descansa en la cara superior de la raíz posterior del ala mayor del esfenoides, cubierto por la porción inferior del lóbulo temporoesfenoidal.

La raíz motora se une a la raíz sensitiva después de atravesar el agujero oval, para formar el nervio maxilar inferior. Llega a la fosa cigomática infratemporal, donde se divide en:

- Rama recurrente meníngea, la cual vuelve a entrar por el agujero espinoso con la arteria meníngea media para inervar la duramadre de la fosa craneal media y la mucosa de las celdillas mastoideas.

- Nervio pterigoideo medio, pequeña rama para la parte más profunda del músculo pterigoideo medio.

- Nervio masetero, que llega al músculo de su mismo nombre.

- Nervios temporales profundos, que se dirigen a la profundidad del músculo temporal.

- Nervio bucal, que recoge la sensibilidad de la piel que cubre el músculo bucinador, cuya inervación motora procede de la rama bucal del VII par.

- Nervio pterigoideo lateral, para la profundidad del músculo pterigoideo lateral.

- Nervio auriculotemporal, recorre la parte posterior de la mandíbula, vuelve hacia arriba con la rama superficial de la arteria temporal, bajo la glándula 
parótida, y asciende sobre el arco cigomático. Se acompaña de fibras postganglionares parasimpáticas (procedentes del IX par y del ganglio ótico) para la glándula parótida. También se relaciona con ramas del VII par. Se divide en varias ramas:

* Auricular anterior, que inerva la piel de hélix y trago

* Rama del conducto auditivo externo, para la piel de dicho conducto y la membrana timpánica

* Ramas articulares, para la articulación temporomandibular

* Ramas temporales superficiales, que acompañan a la arteria temporal superficial hasta el vértice de la base del cráneo, para inervar la piel de la región temporal

- Nervio lingual. Inerva la mucosa oral y los dos tercios anteriores de la lengua. Se une al nervio cuerda del tímpano (rama del VII par), que transmite "el sabor" de los dos tercios anteriores de la lengua y proporciona fibras parasimpáticas para el ganglio submandibular. Pasa entre el músculo pterigoideo medial y la rama de la mandíbula, cruzando oblicuamente para llegar a la lengua.

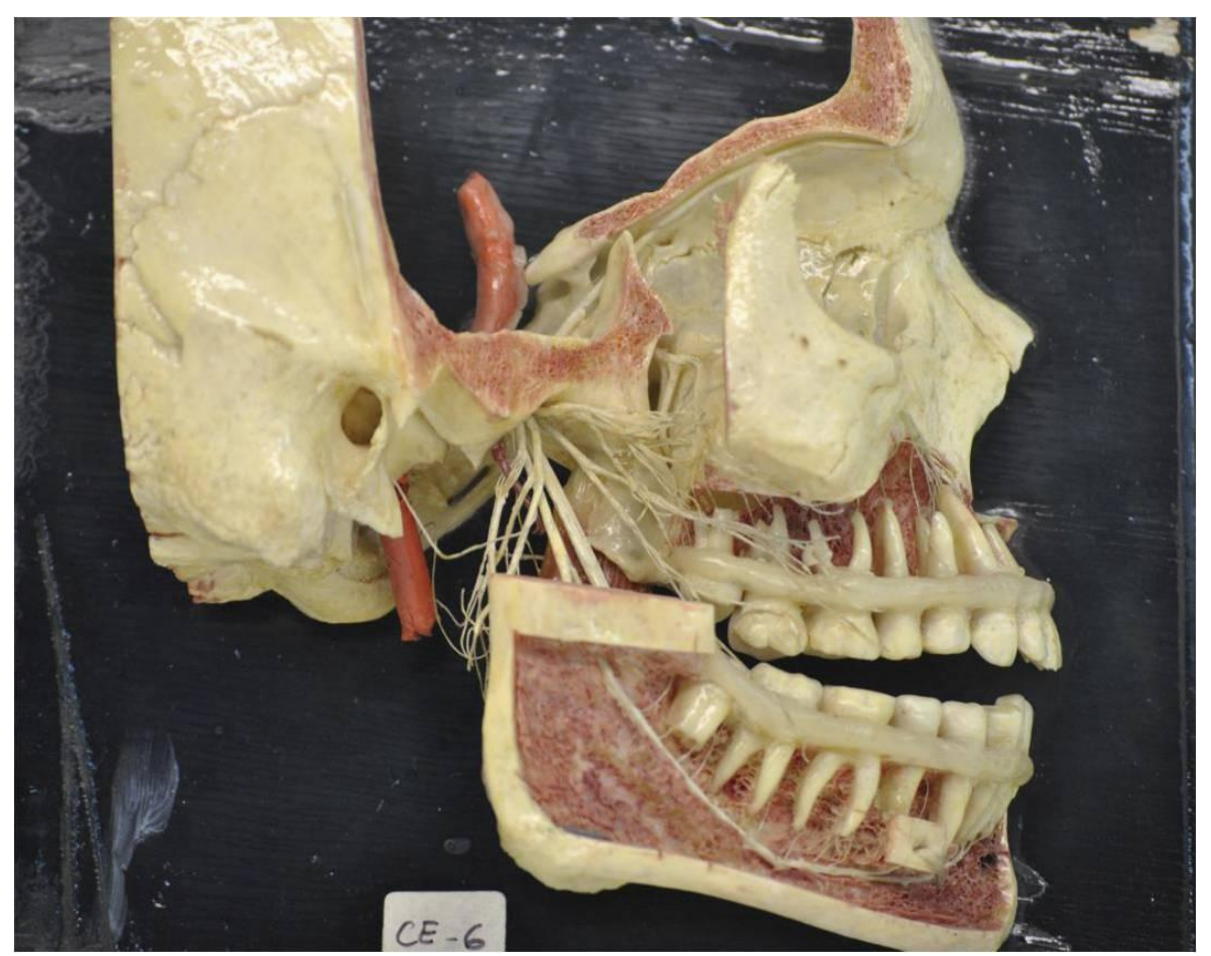

Figura 37.- Representación del nervio mandibular y sus ramas sobre un modelo anatómico en cera (gentilmente cedido por el Museo Anatómico de la Facultad de Medicina de Valladolid) 
- Nervio alveolar inferior. Es la rama más larga del nervio mandibular. Desciende junto a la rama de la mandíbula hacia el orificio mandibular para entrar en el canal mandibular y emitir las siguientes ramas:

* Ramas dentales, para los molares y premolares mandibulares

* Rama incisiva, para los caninos e incisivos mandibulares

* Nervio mentoniano, que emerge por el orificio mentoniano para inervar la piel del mentón y el labio inferior.

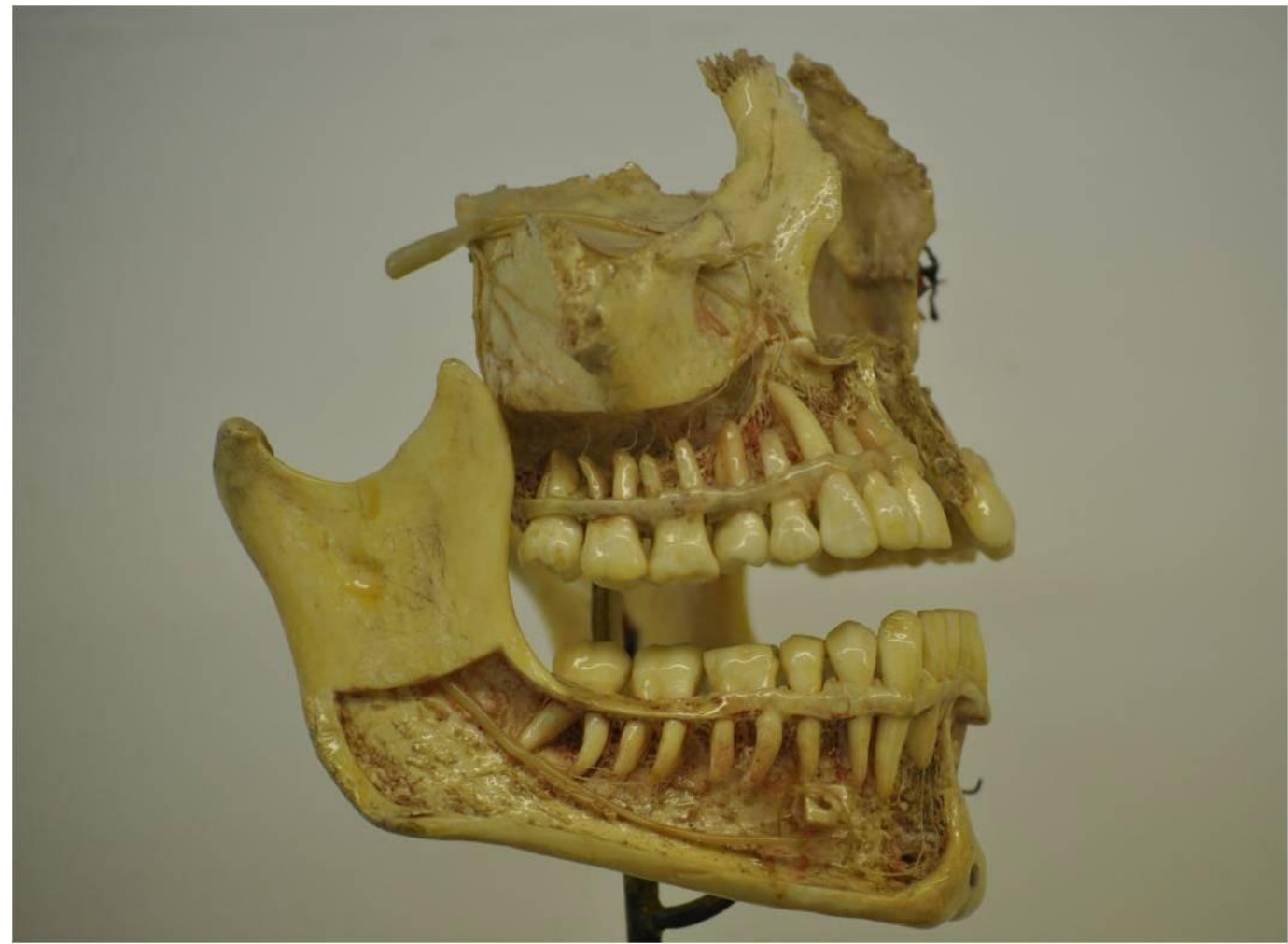

Figura 38.- Representación del nervio alveolar (dentario inferior) sobre un modelo anatómico en cera (gentilmente cedido por el Museo Anatómico de la Facultad de Medicina de Valladolid)

El componente motor del nervio mandibular proporciona inervación motora para los siguientes músculos de la masticación:

- Masetero

- Temporal

- Pterigoideo medial

- Pterigoideo lateral

- Músculo del martillo 
- Tensor del velo del paladar

- Milohiodeo

- Vientre anterior del músculo digástrico

\section{5.- Encuesta de satisfacción}

Tras la encuesta de satisfacción efectuada, los resultados obtenidos fueron los siguientes:

Las medias de los datos que se muestran en las gráficas 1 y 2 , reflejan que para todos los usuarios encuestados (tanto profesionales como estudiantes) valoraron muy positivamente la aplicación informática, mostrando un alto grado de satisfacción con el desarrollo didáctico empleado.

En el caso de los profesionales encuestados (gráfica 1), aunque en la mayor parte los ítems formulados superaron el valor 4 (parcialmente de acuerdo); muy próximos en ocasiones al valor 5 (totalmente de acuerdo). Llama la atención el ítem número cinco, en el que según los profesionales encuestados el contenido incorporado podría ser aún más exhaustivo. Este dato contrasta, con lo que comentan los alumnos, en los que en este caso, les parece muy adecuado y muy suficiente. Este aspecto parece fácilmente comprensible, dadas las diferencias en los conocimientos entre unos y otros.

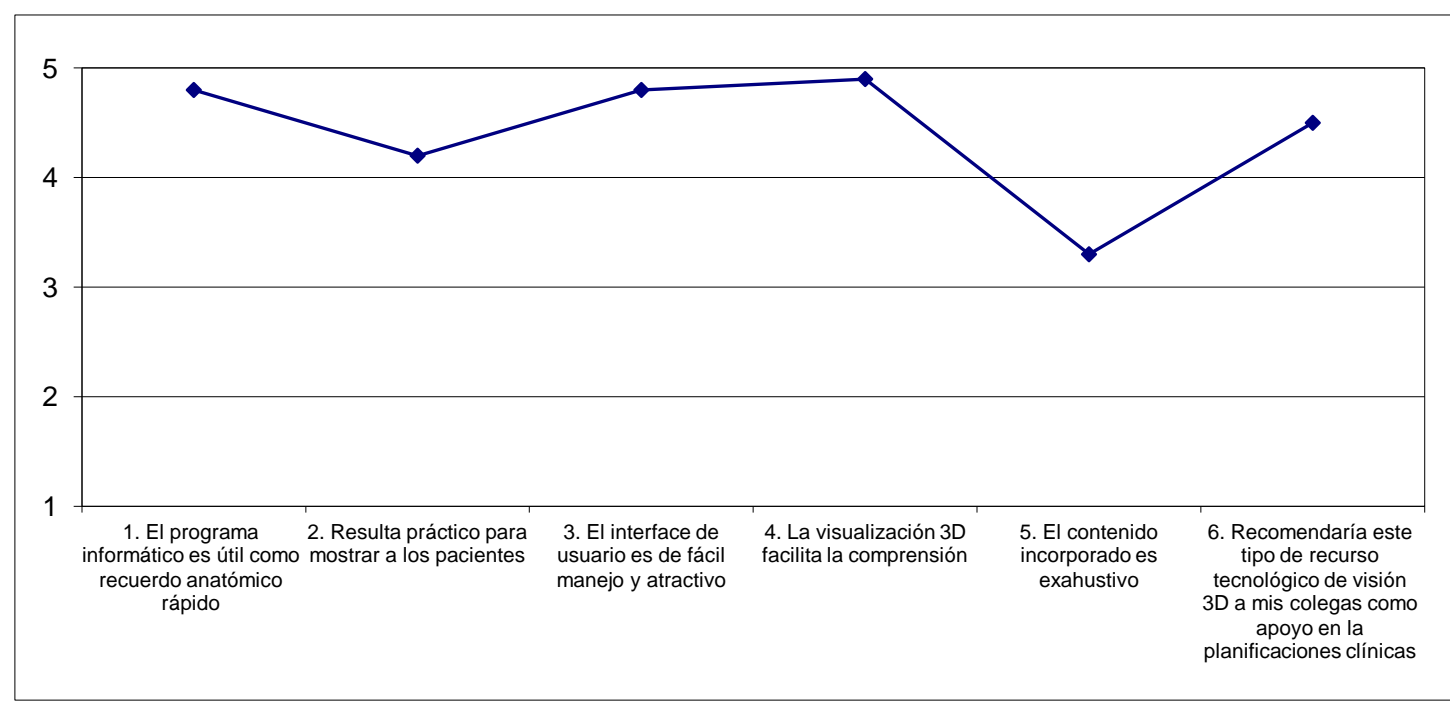

Gráfica 1.- Valores medios recogidos en la encuesta de satisfacción efectuada a los profesionales de diferentes ámbitos (Odontólogos, estomatólogos y cirujanos maxilofaciales). 
Los valores reflejados para las encuestas formuladas a los estudiantes del último curso de Odontología, se observa, en la gráfica 2. Los alumnos manifiestan que el empleo de este recurso informático, como material de apoyo y complementario a su proceso formativo, supone una facilidad para mejorar los resultados de la evaluación de los conocimientos adquiridos durante su proceso formativo. Posiblemente estos sistemas de consulta interactivos, motivan al estudio al tratarse de medios muy dinámicos y atractivos para los usuarios.

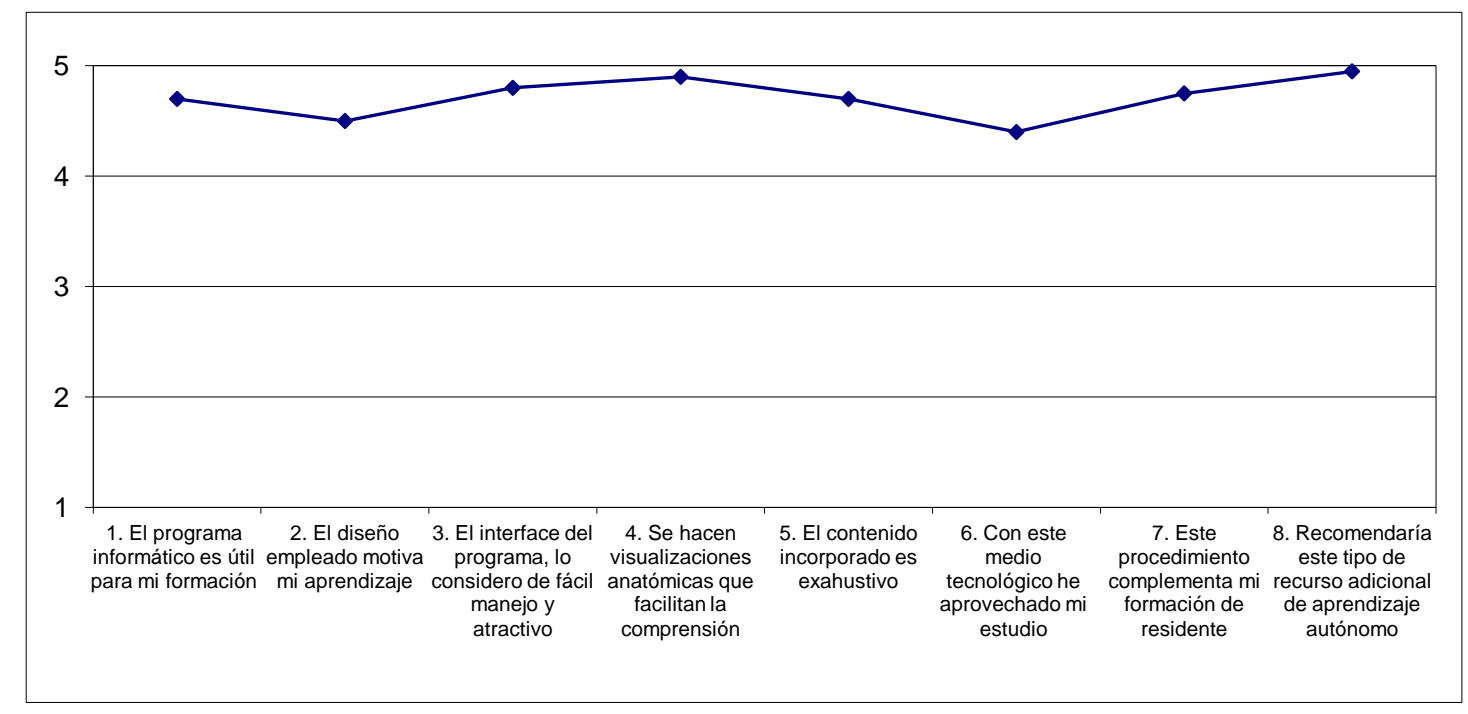

Gráfica 2.- Valores medios recogidos en la encuesta de satisfacción efectuada a los alumnos del último curso de la Licenciatura en Odontología.

Parece claro que estamos abocados a un futuro, en donde estos sistemas de visualización tridimensional de estructuras corporales, se está imponiendo fuertemente, incrementándose cada vez más la lista de nuevas aplicaciones. Estos sistemas de simulación en tres dimensiones, permiten llevar a cabo pruebas y experimentos evitando así un elevado costo, y en ocasiones un grado de peligrosidad en ciertas tareas. Es obvio, que un ordenador no puede sustituir la experiencia directa, pero, en muchas ocasiones, debido a la imposibilidad de acceder a estas experiencias, es donde la simulación con ordenador resulta un instrumento auxiliar muy valioso. Este fenómeno del que apenas en nuestro país empezamos a entrever sus posibilidades, jugará un papel importante en los métodos de enseñanza de las ciencias experimentales y de la salud, y sin duda, cambiará el rumbo de nuestros sistemas docentes. 
Tras la experiencia realizada con este trabajo, podemos terminar este apartado de nuestra Tesis Doctoral señalando, que nuestro procedimiento docente constituye una herramienta informática rigurosamente cuidada y elaborada, para que los usuarios, en el campo de las ciencias de la salud, y especialmente en el campo de la odontología y estomatología puedan desarrollar, de forma autónoma, todo el proceso de formación como si estuviera guiado por el profesor o el tutor, que es quien ha coordinado y controlado toda la acción didáctica. 
DISCUSIÓN 
El trabajo de Tesis Doctoral desarrollado se enmarca dentro del campo de una Anatomía virtual, como un nuevo concepto de visualización interactiva de las imágenes anatómicas, en el que el usuario decide el ángulo o posición espacial de visión. Por ello, en este capítulo de Discusión, analizaremos distintos aspectos de interés, en relación con el desarrollo tecnológico llevado a cabo y las relaciones con procedimientos informáticos aplicados a la formación clínica, terminando con las ventajas y los inconvenientes de este nuevo enfoque de la Anatomía virtual. Por otra parte, la importancia que hoy juega las técnicas de diagnóstico por imagen en la identificación de estructuras anatómicas, hace que estos procedimientos merezcan una atención especial.

Los grandes avances tecnológicos de las últimas décadas y su aplicación al campo de la Medicina y, más concretamente, al de la Odontología, han supuesto una auténtica revolución en el progreso de las técnicas de imagen y su empleo en labores diagnósticas (Koralakunte y Aljanakh, 2014).

La aparición de un gran número de nuevos métodos diagnósticos obliga a los clínicos, por una parte, a tener permanentemente actualizados sus conocimientos sobre los mismos y, por otra, a tener que decidir constantemente que prueba complementaria solicitar en cada circunstancia particular (Aps, 2010).

La Odontología ha experimentado en las últimas décadas una enorme expansión tanto desde el punto de vista científico como en todo lo relativo a sus aplicaciones prácticas, lo que hace difícil abarcar todos estos avances y, en la práctica, son los odontólogos y estomatólogos los que tienen mayores 
dificultades para mantener actualizados sus conocimientos y poder articularlos de una forma racional.

El desarrollo de nuevos métodos para la obtención de imágenes, y la evolución tecnológica nos ha proporcionado mejoras en la calidad de las imágenes convencionales mediante nuevos soportes de la imagen. La imagen digitalizada proporciona unas ventajas adicionales como son la mayor sencillez de almacenamiento y la posibilidad de procesamiento electrónico posterior de las imágenes (Asensio, 2005).

En la actualidad disponemos de una gran variedad de técnicas modernas para la obtención de imágenes del aparato dentario que permiten, en correcto equilibrio con los métodos tradicionales, mejorar sensiblemente las posibilidades diagnósticas (Alexander, 1976; Mancuso y Hanafee, 1985; Horch y cols., 1995; Spitzer, 1995; Palomo y cols., 2004; Hajeer y cols., 2005; Hamada y cols., 2005; Hoffmann y cols., 2005; Nakasima y cols., 2005; Schulze y cols., 2005; Westermark y cols., 2005). Asi, el procedimiento de examen radiográfico más utilizado en Odontología, corresponde a la radiografía intraoral. Dentro de esta técnica se diferencian tres tipos: periapical, oclusal y de aleta de mordida (Carranza, 1990; Verdasco y cols., 1994; Hernandez, 1998; Macorra, 1998; Clark y Curzon, 2004; Goga y cols., 2004; Khan y cols., 2004; Emmott, 2005; Erten y cols., 2005).

La técnica periapical, también conocida como retroalveolar, es de gran utilidad en la valoración detallada del diente y del proceso alveolar, de un sector determinado del maxilar superior o inferior, y como orientación de la clase de trabeculación ósea. La más clásica y frecuente en la práctica odontológica, es la técnica periapical bisectriz, en la que el rayo central incide perpendicularmente a la bisectriz formada por el eje dentario y el eje de la película pasando a través del ápice dentario. Sin embargo, la técnica periapical en paparelismo es la de elección en los casos de valoración periodontal o implantológica del paciente. Es muy útil a la hora de valorar el espacio mesiodistal disponible en un sector 
concreto, o entre un diente y una estructura anatómica como el seno maxilar o el agujero mentoniano, pero si no se realiza de forma correcta, puede dar lugar a errores en la medida de la anchura observada por la distorsión que se produce debido a las diversas formas anatómicas y a la dificultad de colocación de la película, con la limitación añadida del pequeño campo observado.

En la actualidad hay en el mercado diferentes sistemas de radiología intraoral digital que, manteniendo una buena resolución, disminuyen la dosis que recibe el paciente e incorporan diferentes programas de tratamiento de imágenes con posibilidades de medida de densidades, etc..

La técnica oclusal proporciona una imagen completa del maxilar superior o de la mandíbula con escasa magnificación dado que la película se sitúa en contacto con los dientes o con el reborde alveolar.

Sirve para evaluar la anchura mandibular, maxilar y la posición, en sentido vestíbulo-lingual, del conducto dentario inferior, pero debido a la superposición de todo el espesor mandibular, no es demasiado fiable, siendo por el contrario de gran utilidad en la comprobación de perforaciones de la cortical durante la colocación de implantes.

La técnica de aleta de mordida, permite visualizar el reborde óseo marginal y las coronas de los dientes tanto superiores como inferiores, por lo que sus indicaciones principales son la localización de caries interproximales, detección de obturaciones desbordantes, determinación del ajuste de prótesis fijas, descubrimiento de depósitos de sarro, etc.

Pese a sus deficiencias y a la necesidad de realizar radiografías complementarias, la radiografía panorámica u ortopantomografía ha demostrado su utilidad como medio diagnóstico. La radiografía panorámica proporciona una representación radiológica de conjunto de todo el aparato masticatorio, del maxilar superior, de la mandíbula, de las articulaciones temporomandibulares y de la región mediofacial (Aguirre y Caballero, 1995; Alandez y cols., 1996; 
Acero y Somacarrera, 1998; Lucas y cols., 1998; Lee y cols., 2004; Legovic y cols., 2004; Molander y cols., 2004; Alhaija, 2005; Sedaghatfar y cols. 2005; Asensio, 2005).

La tomografía computarizada (TC), técnica fundamental empleada en nuestro trabajo de reconstrucción tridimensional de estructuras del aparato dentario, se basa en la visualización radiológica detallada de los órganos en un plano corporal correspondiente al plano de rotación de un sistema móvil constituido por el tubo de rayos $\mathrm{X}$ y el sistema receptor.

La ventaja de las imágenes tomográficas es la posibilidad de visualizar estructuras determinadas evitando superposiciones. Por el contrario, tienen como inconveniente una pérdida de contraste y de precisión, sobre todo cuando se trata con estratos muy finos. La visualización tomográfica del esqueleto maxilofacial supera a las imágenes convencionales, principalmente en la determinación de la relación espacial de los dientes incluidos con el nervio dentario inferior.

La TC permite la visualización de las partes blandas, pudiéndose determinar la densidad y el grado de vascularización de algunos procesos expansivos mediante la inyección de un contraste intravenoso. Por tanto su principal ventaja es la visualización simultánea de huesos y partes blandas con gran definición de densidades (Arana-Fernández de Moya y cols., 2006; Lenguas y cols., 2010; Oviedo-Muñoz y Fernández-Añaños, 2012).

Un inconveniente relativamente frecuente de esta técnica diagnóstica es la presencia de cuerpos metálicos, materiales de osteosíntesis y prótesis dentales, que pueden generar artefactos que deterioran sensiblemente las imágenes (Pasquet y Cavezian, 1993; Yanagisawa y cols., 1993; Muñoz y cols., 1998; Rothman, 1998; Alberico y cols., 2000; Cova y cols., 2003; Donado y cols., 2003; Kim y cols., 2003; Scribano y cols., 2003; Varvara y cols., 2003; Baba y cols., 2004; Mupparapu y Singer, 2004; Nkenke y cols., 2004; Podesser y cols., 2004; Katsumata y cols., 2005; Rachmiel y cols., 2005; Suomalainen y cols., 2007; Lenguas y cols., 2012). 
Por otra parte, en la exploración del aparato dentario, es necesario valorar, de forma metódica y minuciosa, forma, tamaño, color, número, posición, etc...; buscando en cada exploración si existen trastornos de tipo conoidismo, dislaceración, taurodontismo; pigmentaciones exógenas o endógena; micro o macrodoncias, agenesias, supernumerarios, pérdidas dentarias, mal posiciones, interferencias, hipersensibilidad y caries, abrasión, erosión e hipoplasias, maloclusiones, diastemas, apiñamientos.

En el examen del sistema dentario se deben incluir: Palpación: cuando sospechamos un traumatismo dentario por un contacto prematuro. Percusión: que nos indica la presencia de afectación periodontal y nos orienta acerca de su origen (pulpar o periodontal). Movilidad: que nos informa del grado de soporte óseo. Pruebas de vitalidad: físicas, químicas o eléctricas, para conocer el estado y grado de reacción pulpar. Transiluminación: para la detección de caries.

Finalmente, el examen radiográfico será fundamental e imprescindible para el trabajo diario odontológico: ortopantomografía como examen general inicial, periapicales para finos detalles anatómicos, oclusales para determinados procesos patológicos, de aleta de mordida para el diagnóstico de caries interproximales, etc. (Bagan y cols., 1995; Bascones y Llanes, 1996; Blanco y cols., 1998.).

Ante estas consideraciones exploratorias y diagnósticos se extrae, como consecuencia, el necesario conocimiento anatómico de la zona por parte de odontólogos y estomatólogos, por lo que desarrollos informáticos como el propuesto suponen un apoyo y una guía adicional, de gran interés formativo, al poder valorarlo en tres dimensiones y en cualquier posición espacial; siendo además una reproducción anatómica fiel, del aparato dentario.

La mejora de la formación en ciencias de la salud, resulta ser uno de los anhelos más importantes de todos los profesionales docentes dedicados a este campo. 
La enseñanza es una actividad intencional, diseñada para dar lugar al aprendizaje de los alumnos. Pero ligar los conceptos de enseñar y aprender es una manera de manifestar que la situación que nos interesa es algo más que la relación de acciones instructivas por parte del formador y la relación de efectos de aprendizaje en los estudiantes (Boet y cols., 2014)

Los procesos de enseñanza-aprendizaje ocurren en un contexto institucional, transmitiéndole así unas características que trascienden a la significación interna de los procesos, al conferirle un sentido social (Beccaría y Rey, 1999).

Los procesos de enseñanza-aprendizaje pueden interpretarse bajo las claves de los sistemas de comunicación humana, teniendo en cuenta las peculiaridades especificas de aquéllos, una de las cuales es su carácter de comunicación intencional. La intencionalidad nos remite tanto a su funcionalidad social como a su pretensión de hacer posible el aprendizaje (Contreras, 1990).

El docente debe prever, seleccionar y organizar los recursos didácticopedagógicos que integrarán cada situación de aprendizaje, con la finalidad de crear las mejores condiciones para lograr los objetivos previstos (Rodríguez Lamas, 2002). En nuestro trabajo de Tesis Doctoral se ha buscado que la aplicación informática desarrollada cumpliera con los propósitos de aclarar y ayudar al aprendizaje del aparato dentario, de una forma autónoma, aunque guiada por el docente que es quien ha desarrollado el procedimiento formativo; intentando siempre que el recurso didáctico fuese sencillo de manejar y conciso en sus contenidos docentes.

Como ya hemos señalado anteriormente, la enseñanza es una actividad intencional, diseñada para dar lugar al aprendizaje de los alumnos. Por ello la mejora del aprendizaje resulta ser uno de los anhelos más importante de todos los docentes. 
El sentido interno de los procesos de enseñanza-aprendizaje está en hacer posible el aprendizaje.

La informática como recurso didáctico-pedagógico va adquiriendo un papel más relevante a medida que la moderna tecnología se va incorporando a la tarea educativa (Rivera Porto, 1993).

En los últimos años, los avances de las tecnologías informáticas y de las últimas técnicas de comunicación, se han incorporado al terreno formativo en las ciencias de la salud con el objetivo de elevar la eficiencia del proceso docente y en la búsqueda por aportar a la enseñanza una base más científica y técnica que haga más productiva la docencia en esta área de conocimiento.

El proceso de la introducción de estas tecnologías en la enseñanza de la odontología y estomatología y en otras disciplinas de las ciencias de la salud, ha sido progresivo, en función de las características y requerimientos de los distintos procesos educativos de cada centro universitario.

Parte de esta tecnología, no solo ha sido de hardware, sino también han entrado a formar parte de los sistemas docentes de los profesores universitarios, diversos desarrollos informáticos catalogados ya en sus guías académicas como software educativo, los cuales han sido creados para ser utilizados en la docencia tanto presencial como a distancia a través de redes colaborativas.

Los programas informáticos, como recursos didácticos en la formación médica, constituyen una herramienta muy útil en todas las materias de las ciencias de la salud (Shortliffe y Perreault, 1990; Roger y Santucci, 1987).

Es evidente que cada vez existe una mayor disponibilidad de equipos informáticos, de altas prestaciones tecnológicas, que hace posible satisfacer las necesidad óptimas de ejecución de muchos programas informáticos docentes con características hipermedia que requieran de una alta capacidad de memoria de los ordenadores donde se van a ejecutar (Salinas, 1994). 
La Informática Educativa utiliza el ordenador como enseñanza o como medio de programación (Rivera Porto, 1993). Existen diferentes enfoques, siendo la resolución de problemas la que se podría considerar como la forma más amplia de aprendizaje, en la que se espera, como norma, que los alumnos desarrollen estas técnicas mediante un proceso poco definido de ejemplificación y ejecución.

En este caso, el aprendizaje está individualizado y el alumno crea un propio programa, lo cual le ayuda al desarrollo de técnicas generales de resolución de problemas y el estudiante empieza a concebir sus errores como una fuente de aclaración y no como motivo de desesperación, la tendencia de este enfoque es el cognoscitivo de la enseñanza y el aprendizaje, donde se conciben a los ordenadores, como dispositivos para elaborar un sistema de enseñanza que tratan al alumno como un ser que piensa y participa en su proceso de aprendizaje (Alvarez, 1984).

En este sentido nuestro programa informático para el estudio del aparato dentario, está basado en un sistema tipo tutorial encargado de presentar la información y guiar al usuario (estudiante) en su aprendizaje inicial.

Por otra parte, los desarrollos informáticos basados en la simulación, constituyen un poderoso método tecnológico que enseña al usuario sobre algún aspecto concreto que se encontrará en su actividad profesional, imitándolo o replicándolo. Los estudiantes no solo se motivan por la simulación, sino que también aprenden interactuando con ella, de manera similar a como pudieran hacerlo en situaciones reales.

En casi todos los casos, la simulación, en el terreno de las ciencias de la salud también hay simplificación de la realidad al omitir o cambiar detalles. El propósito es ayudar, al estudiante de medicina u cualquier otra área de la salud o incluso residentes hospitalarios, a construir un modelo mental útil, darle una oportunidad de probarlos, sin riesgos y eficientemente y, que aprenda realizando actividades en un contexto similar al que se encontrará en la vida real. 
En este sentido, existen en el mundo muchos grupos de trabajo relacionados con la información médica en forma de imágenes clínicas. A modo de ejemplo podemos destacar grupos que han llevado a cabo desarrollos informáticos mediante un navegador en Java, que visualiza imágenes tridimensionales del cuerpo humano. Otros grupos han desarrollado una aplicación de visualización tridimensional destinada a ser utilizada por neurorradiólogos y neurocirujanos en simulaciones. Otros proyectos, más teóricos, consideran diversos aspectos del análisis y tratamiento de imágenes médicas, elaborando representaciones multiescala con diverso nivel de detalle. También, surgen grupos que trabajan en herramientas de trabajo colaborativo basadas en Internet para radiología. Algunos proyectos de trabajo están elaborando un modelo de acceso a bases de datos médicos a través de Internet, estableciendo dinámicamente un repositorio virtual de información que pueda ser útil tanto a profesionales de las ciencias médicas como para estudiantes e incluso los propios pacientes (Anderson y Jay, 1987; Gervás, 1987; Bakker y cols., 1988; Enriquez y Martínez, 1991).

Técnicas avanzadas de Inteligencia Artificial (Fiesch, 1987) se han empleando en otros trabajos que extraen las denominadas reglas de predicción clínica, procesando bases de datos epidemiológicas, y en aplicaciones que organizan la información tratando los términos utilizados y poniéndolos en relación con vocabularios médicos normalizados, construyendo un servidor de vocabulario.

En todos estos procedimientos tecnológicos, como ocurre con otros productos de la actual tecnología formativa en ciencias de la salud, no se puede afirmar que el software docente por sí mismo sea bueno o malo, todo dependerá del uso que de él se haga, de la manera cómo se utilice en cada situación concreta. En última instancia su funcionalidad y las ventajas e inconvenientes que pueda comportar su uso serán el resultado de las características del material, de su adecuación al contexto formativo al que se aplica y de la manera en que el profesor organice su utilización didáctica. 
La mayoría de los programas docentes informatizados, a través de sus actividades, presentan unos contenidos que proporcionan una información a los estudiantes. Como todos los medios didácticos, estos materiales representan la realidad y la ordenan. Los programas tutoriales, los simuladores $\mathrm{y}$, especialmente, las bases de datos, son los programas que realizan más marcadamente una función informativa. Todos los programas educativos orientan y regulan el aprendizaje de los estudiantes ya que, explícita o implícitamente, promueven determinadas actuaciones de los mismos encaminadas a facilitar el logro de unos objetivos educativos específicos.

Si bien el ordenador actúa, en general, como mediador en la construcción del conocimiento de los estudiantes, son los programas tutoriales los que realizan de manera más explícita esta función instructiva, ya que dirigen las actividades de los estudiantes.

La revolución de la informática médica, iniciada hace muchos años e intensificada, en la última década, ha abierto una revolución en la formación en las ciencias de la salud.

Entre las aplicaciones más destacadas que ofrecen la utilización de las tecnologías informáticas al terreno formativo se encuentran los recursos de características hipermedia (Salinas, 1994) los cuales se insertan rápidamente en el proceso de enseñanza-aprendizaje de los usuarios que los manejan. Esto es así, porque refleja fielmente la manera en que el alumno o usuario, piensa, aprende y recuerda, con los programas informáticos al explorar fácilmente textos, imágenes, sonidos, animaciones y videos, para estudiar, analizar, reflexionar e interpretar en profundidad la información utilizada (Marqués, 1999).

En consecuencia, la tecnología multimedia e hipermedia, se convierte en una poderosa y versátil herramienta que transforma a los usuarios (alumnos, residentes, jóvenes especialistas, etc.) de receptores pasivos de la información en participantes activos, en un enriquecedor proceso de aprendizaje en el que desempeña un papel primordial la facilidad de relacionar sucesivamente distintos 
tipos de información, personalizando la formación, al permitir a cada usuario avanzar según su propia capacidad.

Sin embargo, nosotros queremos reflejar que, la mera aplicación de estas tecnologías en la formación, no asegura la obtención de mejores alumnos, si entre otros requisitos, dichos procesos no van guiados y acompañados por la labor y la participación activa del docente que es quién coordina y dirige toda la acción didáctica (Avolio, 1981). El docente debe seleccionar cuidadosamente todo el material y el contenido docente que deben incluirse en los programas informáticos para que el usuario los estudie y aprenda con ellos.

Por eso, es necesario que los desarrollos informáticos de características docentes establezcan una metodología de estudio y de aprendizaje para que el alumno no convierta la información incluida en un programa informático, en un simple libro animado, en el que el usuario consuma grandes cantidades de información que no aporten demasiado a su formación médica personal. Este aspecto ha sido muy tenido en consideración en nuestra aplicación informática.

De ahí que, sobre todo el docente, tiene que tener la precaución no sólo de examinar cuidadosamente los contenidos de cada material a utilizar para detectar posibles errores, omisiones, ideas o conceptos equívocos, sino que también deberá fomentar entre los alumnos una actitud de juicio crítico frente a lo que estudia con el empleo de material didáctico tecnológico (Jiménez y cols., 1989).

Cada día surge gran variedad de software educativo en el terreno médico, lo que permite generar una amplia base documental de desarrollos informáticos que facilitan y mejoran el aprendizaje. De esta forma, además, los alumnos podrán ir adquiriendo las habilidades y destrezas que seguramente manejaran en su actividad profesional.

Las expresiones software educativo, programas educativos y programas didácticos o docentes, se emplean como sinónimos para designar genéricamente los programas para ordenador creados con la finalidad específica de ser utilizados 
como medio didáctico, es decir, para facilitar los procesos de enseñanza y de aprendizaje (de Pablos y Gortari, 1992). Esta definición engloba todos los programas que han estado elaborados con un fin didáctico, desde los tradicionales programas basados en los modelos conductistas de la enseñanza, conocidos clásicamente como programas de Enseñanza Asistida por Ordenador (EAO), hasta los programas experimentales de Enseñanza Inteligente Asistida por Ordenador (EIAO) que, utilizando técnicas propias del campo de los Sistemas Expertos y de la Inteligencia Artificial en general, pretenden imitar la labor tutorial personalizada que realizan los profesores y presentan modelos de representación del conocimiento en consonancia con los procesos cognitivos que desarrollan los alumnos (Cuena, 1986).

Lo que parece evidente, es que los modernos programas informáticos docentes que surgen en el campo de las ciencias de la salud, favorecen la flexibilidad del pensamiento de los usuarios que los emplean, ya que estimulan la búsqueda de distintas soluciones para una misma actividad planteada, permitiendo un mayor despliegue de los recursos cognitivos de los alumnos.

La utilización del ordenador en la docencia implica un mayor grado de abstracción de las acciones, una toma de conciencia y anticipación de lo que muchas veces hacemos "automáticamente"; de esta forma conseguiremos estimular en nuestros alumnos las conductas operatorias (actúa y toma decisiones) en lugar de las conductas sensorio-motoras (sólo escucha y escribe).

Por otro lado, desde el punto de vista afectivo y social, el manejo de programas informáticos docentes permite el trabajo en equipo, apareciendo así la cooperación entre sus usuarios y la posibilidad de intercambiar puntos de vista entre los alumnos, lo cual favorece también, sin lugar a dudas, sus procesos de enseñanza-aprendizaje. De esta forma, el alumno es un sujeto activo y participante de su propio aprendizaje que puede desarrollar usos y aplicaciones de lo que estudia a través de la inserción de las nuevas tecnologías. 
El ordenador, a través de los programas formativos, constituye además, para el docente, un instrumento capaz de revelar, paso a paso, el avance intelectual de los alumnos (Bartolomé, 1989).

Pero para favorecer este proceso de enseñanza-aprendizaje de los alumnos de una titulación como es la de Odontología, el docente deberá ser, ante todo, una persona capaz de acompañar a sus alumnos en este crecimiento de aprendizaje que van realizando.

Deberá ser capaz de plantear conflictos cognitivos y dudas que surjan en los alumnos, apoyándolos en la construcción de sus estructuras de conocimientos. También deberá colaborar con ellos para que integren el error como parte del proceso de aprendizaje que están llevando a cabo, impulsándolos a reflexionar sobre la lógica de sus equivocaciones.

Los docentes, hoy se encuentran ante un volumen creciente de materiales curriculares y elementos auxiliares de enseñanza: libros de texto, ordenadores, software educativo, medios audiovisuales. Sin embargo, disponen de pocas referencias de utilidad general que pudieran ayudarlos a hacer sus selecciones; algunas de ellas, significan decisiones sobre lo que se va a enseñar; otras encierran selecciones de medios en los cuales el contenido, ya elegido, ha de ser presentado. Para muchos profesores, muchas de estas ideas modernas, son difíciles de entender, de aceptar y de armonizar con los antiguos conceptos de educación adquiridos por los docentes. Un particular criterio a desarrollar en los docentes, ha de ser el de elegir adecuadamente los diferentes software educativos a emplear en la formación de sus alumnos, considerando el nivel de éstos, la didáctica de enseñanza y los requerimientos técnicos para su correcta utilización como apoyo a la docencia.

La evolución experimentada durante los últimos años, en la implementación de proyectos de informática educativa, promueve el desarrollo de diversas acciones entre las cuales es necesario destacar la disponibilidad de equipamiento informático adecuado, la utilización del software más conveniente, el debido 
mantenimiento y asistencia técnica de ambos y por último, pero no menos importante, la vigencia de un proyecto institucional promovido por las autoridades universitarias del centro y de la institución general, así como la formación y capacitación de los propios docentes.

Por eso, debemos tener en cuenta que, la mera incorporación de las nuevas tecnologías informáticas a las diversas actividades que se desarrollan habitualmente en la formación académica universitaria de nuestros alumnos, no logra satisfacer las expectativas creadas, si no se tiene en consideración la indispensable necesidad de capacitar simultáneamente los recursos humanos disponibles, a través de un permanente plan de formación y capacitación que incluya el desarrollo de cursos y encuentros que contemple no sólo los aspectos informáticos sino también los didácticos (Castillejo 1986; Ortega y Martínez, 1994).

La mayoría de los programas didácticos, igual que muchos de los programas informáticos nacidos sin finalidad educativa, tienen tres módulos principales claramente definidos: el módulo que gestiona la comunicación con el usuario, el que contiene debidamente organizados los contenidos informativos del programa y el módulo que gestiona las actuaciones del ordenador y sus respuestas a las acciones de los usuarios.

El interface es el entorno a través del cual los programas establecen el diálogo con sus usuarios y es el que posibilita la interactividad característica de estos materiales. Está integrado por dos sistemas: el sistema de comunicación programa-usuario, que facilita la transmisión de informaciones al usuario por parte del ordenador. Incluye las pantallas a través de las cuales los programas presentan información a los usuarios; y el sistema de comunicación usuarioprograma, que facilita la transmisión de información del usuario hacia el ordenador. Incluye: el uso del teclado y el ratón, mediante los cuales los usuarios introducen al ordenador un conjunto de órdenes o respuestas que los programas reconocen. El empleo de otros periféricos: micrófonos, lectores de fichas, 
teclados conceptuales, pantallas táctiles, lápices ópticos, modems, lectores de tarjetas, convertidores analógico-digitales.

Con la ayuda de las técnicas de la Inteligencia Artificial y del desarrollo de las tecnologías multimedia, se investiga la elaboración de entornos de comunicación cada vez más intuitivos y capaces de proporcionar un diálogo abierto y próximo al lenguaje natural (Shirai y Tsujii, 1987).

Los programas educativos, a pesar de tener unos rasgos esenciales básicos y una estructura general común, se presentan con unas características muy diversas: unos aparentan ser un laboratorio o una biblioteca, otros se limitan a ofrecer una función instrumental del tipo máquina de escribir o calculadora, otros se presentan como un juego o como un libro, muchos tienen aspecto de examen, unos pocos asemejan ser sistemas expertos, etc. Pero la mayoría de ellos participan, en mayor o menor medida, de algunas de estas peculiaridades citadas anteriormente.

Los programas docentes pueden catalogarse en distintas categorías, así podemos hablar de programas tutoriales directivos, programas no directivos, programas abiertos o cerrados, etc..

Programas tutoriales directivos, que hacen preguntas a los estudiantes y controlan en todo momento su actividad. El ordenador adopta el papel de juez poseedor de la verdad y examina al alumno. Se producen errores cuando la respuesta del alumno está en desacuerdo con la que el ordenador tiene como correcta. En los programas más tradicionales el error lleva implícita la noción de fracaso.

Programas no directivos, en los que el ordenador adopta el papel de un laboratorio o instrumento a disposición de la iniciativa de un alumno que pregunta y tiene una libertad de acción sólo limitada por las normas del programa. El ordenador no juzga las acciones del alumno, se limita a procesar los datos que éste introduce y a mostrar las consecuencias de sus acciones sobre un entorno. Objetivamente no se producen errores, sólo desacuerdos entre los 
efectos esperados por el alumno y los efectos reales de sus acciones sobre el entorno. No está implícita la noción de fracaso. El error es sencillamente una hipótesis de trabajo que no se ha verificado y que se debe sustituir por otra. En general, siguen un modelo pedagógico de inspiración cognitivista, potencian el aprendizaje a través de la exploración, favorecen la reflexión y el pensamiento crítico y propician la utilización del método científico.

Otra clasificación interesante de los programas atiende a la posibilidad de modificar los contenidos del programa y distingue entre programas cerrados (que no pueden modificarse) y programas abiertos, que proporcionan un esqueleto, una estructura, sobre la cual los alumnos y los profesores pueden añadir el contenido que les interese. De esta manera se facilita su adecuación a los diversos contextos educativos y permite un mejor tratamiento de la diversidad de los estudiantes.

No obstante, de todas las clasificaciones la que posiblemente proporciona categorías más claras y útiles a los profesores es la que tiene en cuenta el grado de control del programa sobre la actividad de los alumnos y la estructura de su algoritmo.

La idea fundamental en el concepto de interfaz es el de mediación, entre usuario y ordenador. Por tanto, la interfaz es lo que "media", o facilita la comunicación o interacción, entre dos sistemas de diferente naturaleza: el ser humano y el ordenador (Shneiderman, 1998).

De una manera más técnica, la interfaz de usuario lo constituye un conjunto de componentes empleados por los usuarios para comunicarse con el programa que se está ejecutando en el ordenador. Es el usuario el que realmente dirige el funcionamiento del programa informático mediante diversas instrucciones de usabilidad.

Podemos decir que, una interfaz es la parte de una aplicación informática que el usuario ve y con la cual interactúa. Está relacionada con la subyacente 
estructura, la arquitectura y el código del software (Shneiderman, 1998). La interfaz incluye las pantallas, ventanas, menús, ayuda, documentación etc.

La interface que mostramos en este desarrollo informático para la visualización de estructuras anatómicas del aparato dentario, es fácil de comprender y muy sencilla de manejar, permitiendo a los usuarios hacer desempeñar una tarea de aprendizaje de la forma más sencilla y rápida. Posiblemente ésta sea una de las principales ventajas que nuestro procedimiento ofrece, además del carácter visual de las imágenes tridimensionales.

Por otra parte, queremos señalar que la evolución de las interfaces de usuario camina en paralelo con la de los sistemas operativos; de hecho, la interfaz constituye actualmente uno de los principales elementos de un sistema operativo (Royo, 2004). Así, el sistema operativo DOS, de los primeros PC, es el estilo más antiguo de interacción entre usuario y ordenador. El usuario escribe órdenes utilizando un lenguaje formal con un vocabulario y una sintaxis propia (los mandatos en el caso del DOS). Se usa un teclado, típicamente, y las órdenes estaban encaminadas a realizar una acción. El usuario no suele recibir mucha información por parte del sistema (ejemplo: indicador del DOS) y debe conocer cómo funciona el ordenador y dónde están los programas (nada está oculto al usuario). El modelo de la interfaz es el del programador, no el del usuario (Shneiderman, 1998).

Las interfaces de menús, contienen una lista de opciones que se muestran en el monitor o en una ventana de la pantalla, para que los usuarios elijan la opción que deseen. Los menús permiten dos cosas: navegar dentro de un sistema, presentando rutas que llevan de un sitio a otro y seleccionar elementos de una lista, que representan propiedades o acciones que los usuarios desean realizar sobre algún objeto.

Los menús contextuales o menús pop-up son los más recientes. Se llaman así porque el contenido del menú depende del contexto de trabajo del usuario. Contienen únicamente las opciones que son aplicables al objeto seleccionado, 
más algunas de uso frecuente que también son accesibles desde el menú de barra. Estas interfaces son ya típicas del sistema operativo Windows.

Las interfaces de menús, bien estructuradas, son buenas para usuarios noveles o esporádicos. Son fáciles de aprender y de recordar. Pueden existir menús simples y avanzados, para adaptarse al tipo de usuario.

Las recomendaciones para este tipo de interfaces es no ocupar demasiado espacio de la pantalla, recordar la información acumulada de menús precedentes, no colocar demasiados elementos en el menú y agruparlos de manera lógica.

Finalmente, otro tipo son las denominadas Interfaces gráficas, conocidos con las siglas, GUIs (Graphical User Interfaces). Fueron desarrolladas originalmente por XEROX (sistema Xerox Star, 1981, sin éxito comercial), aunque popularizadas por Apple (Steven Jobs se inspiró en los trabajos de Xerox y creó el Apple Lisa, 1983, sin éxito, y Apple Macintosh, 1984, con éxito debido en gran medida a su campaña publicitaria).

Una GUI es una representación gráfica en la pantalla del ordenador de los programas, datos y objetos, así como de la interacción con ellos. Una GUI proporciona al usuario las herramientas para realizar sus operaciones, más que una lista de las posibles operaciones que el ordenador es capaz de hacer.

Este prototipo de interfaz es potenciada en nuestro desarrollo informático; entre las características más relevantes podríamos destacar las siguientes:

- Ejecutable y visible en un monitor gráfico de alta resolución.

- Opera con un dispositivo apuntador (ratón).

- Los usuarios pueden ver en la pantalla las imágenes y textos tal como los vería impresos.

- Sigue el paradigma de la interacción objeto-acción.

- Permite la transferencia de información entre programas (captura y archivo de imágenes). 
- Se puede manipular en la pantalla directamente las estructuras anatómicas tridimensionales y su plano de visión.

- Existe una muestra visual de la información y modelos anatómicos 3D a través de iconos intuitivos y ventanas desplegables.

- Proporciona respuesta visual a las acciones del usuario, de forma rápida (rotaciones de imagen, translaciones, zoom, etc.).

- Existen controles gráficos (widgets) para la selección de la información.

- Proporciona una excelente flexibilidad con el uso del ratón, para la navegación por el programa.

Queremos resaltar que, una característica importante de las GUI, es que permite manipular los objetos e información de la pantalla del ordenador y no sólo presentarla. No obstante, a nuestro parecer, sería muy recomendable que cualquier usuario que utilizara nuestra aplicación o cualquier otra de estas características técnicas conociera una serie de conceptos como son la organización del sistema operativo que maneja, diferentes tipos de iconos que aparecen en el programa así como el efecto de las acciones que hacen cuando se pulsa sobre ellos, elementos básicos de una ventana, uso adecuado del ratón (sobre todo en aplicaciones como la nuestra en la que toda la manipulación de las imágenes se realiza a través de él).

Lo que está claro es que esta nueva hornada de interfaces que está por llegar en los próximos meses o años, no será esencialmente diferente de lo que conocemos hoy en día. Un cambio radical de concepción está aún bastante lejano en el tiempo, por lo menos para lo que son los estándares en informática, y además no se conoce ningún desarrollo serio que se esté llevando a cabo en ese sentido. Sin embargo, es de suponer que la evolución de las interfaces gráficas pase por la adopción de las tres dimensiones y de nuevos paradigmas, alejados ya de los tradicionales. No cabe duda que sería muy interesante que la nueva generación de GUIs permitiese manipular la información de formas no ligadas a 
la realidad cotidiana, sino adaptadas a lo que es, algo mucho más abstracto. Así se podría pasar a un nuevo nivel de uso de las computadoras, haciendo previsiblemente más sencilla la manipulación de grandes cantidades de información y aumentando la productividad.

Además de lo anteriormente mencionado para la configuración de nuestro procedimiento informático, hemos tenido en consideración una serie de factores humanos al diseñar nuestra interfaz de usuario. Hemos tenido en cuenta las habilidades cognitivas y de percepción de las personas a las que principalmente va dirigida nuestra aplicación informática (estudiantes y profesionales en el campo de la odontología y la estomatología, sin descartar a los profesionales de la anatomía humana y los estudiantes de Anatomía Humana de la titulación de Medicina), adaptando el programa a todos ellos.

Cada persona tiene unas habilidades muy distintas con el manejo del ordenador, y ésta debe utilizar las suyas para soslayar las de la máquina, tales como:

- La Velocidad de Aprendizaje, con nuestro modelo de interfaz pretendemos que la persona aprenda a usar el sistema lo más pronto posible y le saque el mayor rendimiento para su formación médica en este campo.

- La Velocidad de Respuesta, es decir, el tiempo necesario para realizar una operación entre las diferentes opciones que le ofrece el desarrollo informático.

- La Retención, aspecto muy relevante de nuestro desarrollo informático, encaminado fundamentalmente hacia la formación y enseñanza médica en el conocimiento del aparato dentario, valorando cuánto recuerda o retiene el usuario con el uso de nuestra aplicación en un período de tiempo determinado, así como la ventaja que ofrece este sistema de formación frente a otros procedimientos más tradicionales. 
- La Satisfacción, es decir, si el usuario que maneja el programa está a gusto con el desarrollo y la metodología empleada para su formación.

Por otra parte, además de los aspectos mencionados anteriormente, hemos querido considerar otros que nos parecen igualmente importantes, destacando la visibilidad de las diferentes opciones del programa; la motivación por el programa, lo que hace que esté más tiempo aprendiendo. Esto se consigue si el usuario ve que realiza tareas muy específicas y se imita en gran medida el medio en el que se desenvuelve el usuario y que, sin lugar a dudas, verá en el ejercicio de su profesión con la que se encuentra identificado.

Ante estas consideraciones fue necesario llevar a cabo una prueba con los usuarios para validar, de alguna manera, su satisfacción con el manejo de nuestra herramienta de aprendizaje y como diseño de la misma. Por eso, hicimos una encuesta de satisfacción entre los usuarios potenciales de diferentes centros hospitalarios de nuestro país. Realizamos, por tanto, pruebas de usabilidad del producto, o con los propios usuarios finales del mismo (estudiantes y especialistas en el campo de la odontoestomatología). Los datos mostrados en el capítulo de resultados de nuestra Tesis Doctoral muestran un claro nivel de satisfacción con nuestro desarrollo informático, obteniendo resultados semejantes a los obtenidos por (Reeves y Van Schaik, 2012; King y cols., 2013; Boet y cols., 2014)

Por ello, cuando iniciamos todo el proceso de diseño de nuestro programa informático "centrado en las tareas y habilidades que debería asumir el usuario", tuvimos algunas actividades implícitas en consideración, tales como: quién usará el sistema y para hacer qué; seleccionar las acciones más representativas para el diseño de la interfaz; no plagiar o copiar otros formatos o diseños que ya se hubieran realizado (por lo que nuestro programa es totalmente innovador); bosquejar y pensar un diseño atractivo para el usuario y, finalmente, dejamos la aplicación abierta a posibles y nuevas incorporaciones para mejorar la aplicación. 
Además, hemos intentado en todo momento emplear las técnicas y los pasos más avanzados para el diseño de nuestra interfaz de usuario. Para ello, intentamos no colocar demasiados objetos en la pantalla y los que existen, pensamos que están bien distribuidos, ya que cada elemento visual influye en el usuario no sólo por sí mismo, sino también por su combinación con el resto de elementos presentes en la pantalla.

Por eso, a la hora de construir nuestro diseño informático hemos querido tener en cuenta otros aspectos como el número de elementos visuales que perciben el usuario como por ejemplo el color. Es probablemente el elemento de una interfaz que con más frecuencia es mal utilizado. El color comunica información, no es sólo decorativo; por eso deben utilizarse combinaciones adecuadas. El color debe atraer la atención, pero no cansar después de un tiempo de trabajo. Es especialmente importante seguir las líneas de diseño existentes. Principio básico: diseñar primero en blanco y negro y luego añadir el color.

En nuestra aplicación informática, basada en imágenes en escala de grises como son las secciones de resonancia magnética que hemos empleado para nuestro estudio, hemos reconstruido, a partir de ellas, las estructuras anatómicas, dejando la libertad al usuario para que la dote del color que desee, de esta forma cada persona se identificará con aquello que halla seleccionado por algún motivo específico.

Hemos intentado hacer un buen uso de la terminología, sabiendo que, en ocasiones, existen pequeñas matizaciones o variaciones dependiendo de la especialidad clínica. En todo caso, la nómina anatómica internacional ha sido nuestra guía.

Igualmente hemos llevado a cabo un análisis y una elección de los distintos controladores del sistema informático. En muchas ocasiones tuvimos la duda de qué controles utilizar, dado que no existe una única forma correcta. 
Existen diversas guías de diseño sacadas de expertos y comités, que complementan a las reglas de oro. Por citar algunas de ellas:

- Demasiada simetría puede hacer las pantallas difíciles de leer.

- $\quad$ Si se ponen objetos sin alinear, hacerlo drásticamente.

- Elementos de tamaño y color similares se perciben como pertenecientes a un grupo.

- Asumir errores en la entrada del usuario.

- Diseñar para el usuario, no para demostrar los propios conocimientos tecnológicos.

- Unos gráficos espectaculares no salvarán a una mal interfaz.

En definitiva, el conocimiento de estos puntos clave en la generación de diseños informáticos para la formación en ciencias de la salud, nos permitirán enfocarnos mejor al estudio de la materia.

Las interfaces de usuario, como vínculo de inmersión del usuario en el entorno de trabajo tecnológico actual, realzan su importancia en el desarrollo de nuevos productos, más eficaces, eficientes e interactivos para la formación y enseñanza aprendizaje, que es lo que la sociedad de la información y comunicación demanda.

A partir de la base de datos proporcionada por el proyecto Human Visible han proporcionado modelos anatómicos virtuales que configuran los que se puede llamar Anatomía Virtual (Temkin y cols., 2000; 2002; Hatfield y cols., 2002). Estos modelos permiten el desarrollo en numerosas aplicaciones prácticas, se puede interactuar con ellos e incluso se puede llegar a lo que en la actualidad se denomina el Cuerpo Humano Virtual, sobre el que se puede interactuar y efectuar en él nuestros proyectos (Spitzer y Scherzinger, 2006). 
Muchas Facultades o Escuelas de Medicina utilizan una combinación, para el estudio de la Anatomía, de los métodos clásicos de enseñanza con la disección como modelo junto con modelos virtuales de diferentes estructuras del cuerpo humano. En este sentido Temkim y cols., (2006) desarrollan una página Web basada en la enseñanza de anatomía mediante modelos tridimensionales utilizando la base de datos del Visible Human Male, donde se puede localizar, explorar, seleccionar, extraer, estructuras virtuales de imágenes 2D y 3D.

La Clínica Mayo se ha caracterizado por ser una de las pioneras en la investigación para conseguir imágenes biomédicas que puedan ser visualizadas y analizadas (Robb, 1995; 2001). Con la base de datos del Human Visible y sus imágenes de alta resolución, en la clínica Mayo se ha llevado a cabo diversos proyectos aplicables en la práctica clínica, tanto en el diagnóstico como en el tratamiento, como son: modelos de intervención en la próstata, pudiendo realizar un estudio anatómico de las relaciones de la próstata con los órganos vecinos, posibilidad de analizar las biopsias guiadas de próstata y otros como simulaciones endoscópicas virtuales (Robb y Satava, 1997; Robb 2000) o para realizar procederes anestésicos, así como múltiples aplicaciones docentes (Robb y Hanson, 2006).

Estudios combinados entre especialistas, informáticos y anatomistas (Gehrmann y cols., 2006) han llevado a cabo un atlas interactivo de la mano, elaborado siguiendo los datos del Visible Human; según los autores proporciona nuevos datos interesantes para las intervenciones microquirúrgicas de la mano, que no proporcionan los atlas convencionales, combinando los detalles anatómicos con las nuevas posibilidades de interactuación dirigidas a las tareas de enseñanza de la anatomía y la cirugía.

Deutsch (2006) utiliza la base de datos del proyecto Human Visible para estudios clínicos en gastroenterología tales como simuladores, libros de texto de imágenes de anatomía ecográfica, páginas Web, etc. 
Idénticas posibilidades se pueden ir desarrollando con otros proyectos como el Visible Korean Human (ver Park y cols., 2006) o con el proyecto Chinese Visible Human (ver Zhang y cols., 2006). Sobre este último, combinando su base de datos con imágenes de resonancia magnética de pacientes se hace una reconstrucción tridimensional, enfocada al estudio de la masa cerebral o creando modelos anatómicos virtuales (Li y cols., 2006; Heng y cols., 2006).

Según Spitzer y Scherzinger, (2006) se parte del Human Visible y se espera que alcance un gran desarrollo, orientado en cinco direcciones: Desde la muerte a la vida (y viceversa); desde la estructura a la función; desde el adulto hacia el niño, hombre de mediana edad y viejo; desde lo normal a lo patológico y viceversa; desde lo normal al traumatismo y viceversa.

Los cortes en el cadáver dan una imagen estática de la anatomía, que está, con toda seguridad distorsionada, en mayor o menor grado, debido a los procesos postmorten. Así, es difícil su estudio de determinadas regiones, entre ellas la pelvis femenina, pero además otras como el estudio de la cavidad abdominal o torácica, el estudio de los vasos por falta de presión o el estudio cardiaco o pulmonar que se modifica en el vivo con la función. Por ello en el virtual Human Body se debe partir de cortes no del cadáver sino de imágenes del individuo vivo.

La asociación de la morfología con la función es un dato más complicado, aunque ya se está estudiando $\mathrm{y}$, de hecho, ya existen estudios referidos fundamentalmente a la función muscular, como por ejemplo, los efectos que sobre la mandíbula provocan los músculos masticadores en la masticación (Functional Anatomy of the Visible Human, v1: Head and Neck, UC Center for Human Simulation, 2005) o las consecuencias de la rotación en los movimientos de flexión de la rodilla (Eckhoff y cols., 2003).

Los programas informáticos docentes basados en simulaciones, presentan un modelo o entorno dinámico (generalmente a través de gráficos o animaciones interactivas) que facilitan su exploración y pueden realizar aprendizajes inductivos o deductivos mediante la observación y la manipulación de la 
estructura subyacente; de esta manera pueden descubrir los elementos del modelo, sus interrelaciones, y se pueden tomar decisiones y adquirir experiencia directa delante de unas situaciones que frecuentemente resultarían difícilmente accesibles a la realidad, como puede ser la posibilidad de simular un abordaje quirúrgico de forma virtual, a través del manejo y empleo de diferentes técnicas de imagen diagnóstica que visualizan la realidad anatómica del paciente.

Los estudios de imagen pueden facilitar el conocimiento de la anatomía y el diagnóstico de los procesos patológicos que afectan a las estructuras anatómicas del aparato dentario. Estas técnicas han ido cambiando a lo largo del tiempo, no sólo con vistas a la exactitud diagnóstica en sí, sino también como elemento de decisión fundamental a la hora de establecer un plan terapéutico.

Por eso, en el diagnóstico de los procesos patológicos del aparato dentario tienen un papel preponderante las técnicas de diagnóstico por la imagen. $\mathrm{Su}$ contribución es imprescindible en el estudio de cualquier tipo de proceso patológico del sistema dentario, unas veces como complemento de la exploración, otras estableciendo la necesidad del empleo de otras técnicas diagnósticas, posibilitando la contribución de éstas a través de su localización exacta y como guía para obtener espécimen de este estudio.

Actualmente, varios autores, entre los que nos incluimos, señalan que la reconstrucción y la visualización 3D de estructuras anatómicas aportan una información útil para un posterior diagnóstico clínico ante patologías de cualquier región corporal. Por este motivo, durante los últimos años se ha investigado de forma intensa en este campo con el objetivo de automatizar el análisis de imágenes médicas 3D para el apoyo de las tareas diagnósticas y terapéuticas (Fielding y cols., 2000; Parikh y cols., 2004). Asimismo y de forma paralela al creciente interés que hoy despiertan las técnicas de la imagen en el campo de la exploración diagnóstica, se desarrollan las posibilidades que estos métodos ofrecen en el terreno de las ciencias morfológicas, y en concreto en el campo de la Anatomía Humana, como complemento de la información 
morfológica obtenida por la disección del cadáver. De esta forma es posible ampliar el estudio anatómico de los distintos órganos de nuestra economía, mediante las diferentes técnicas de imagen empleadas en la actualidad (Goh y cols., 2000).

El desarrollo de aplicaciones informáticas que permitan representar modelos anatómicos en entornos virtuales aplicados a la enseñanza de la anatomía humana es otra área de gran interés. En el estudio que presentamos sobre la obtención de un modelo 3D para la visualización de las estructuras del aparato dentario, se obtuvieron imágenes a partir de secciones tomográficas con tomógrafo computarizado, desde un cráneo.

A modo de resumen, queremos finalizar este capítulo de Discusión, de nuestra Tesis Doctoral, indicando que la anatomía virtual presenta ventajas considerables sobre la realidad del cadáver y sobre un paciente, pudiendo además ofrecer diferentes visiones y perspectivas. El modelo virtual es estandarizable, transportable, duradero y permite incorporar la diversidad que existe en nuestra especie, proporcionando la oportunidad de aprender la anatomía a partir del ser humano vivo. La anatomía virtual para poder desarrollarse de una forma adecuada a las necesidades de formación de los profesionales de la salud en sus diferentes fases (formación básica, postgrado y formación continuada) debe ser capaz de integrar en sus modelos, distintas áreas del conocimiento en ciencias de la salud: fisiología, patología, fisiopatología, etc. Para iniciar el camino, que sin duda será largo y para poder desarrollar esta área de forma adecuada, es fundamental la colaboración entre anatomistas, clínicos, radiólogos e informáticos. Pensamos que este trabajo que presentamos es un ejemplo claro de esta colaboración entre las distintas especialidades.

Por otra parte, este trabajo de Tesis Doctoral, ha pretendido proporcionar al profesional de la odontología y la estomatología un instrumento de ayuda del que puedan extraer aquellos conocimientos anatómicos que le son precisos en su 
actividad diaria de forma rápida y sencilla, para lo que aportamos este material tecnológico, de visualización tridimensional, cuidadosamente seleccionado.

En las últimas décadas, el progreso de la Medicina, y por ende de la práctica de la Odontología, ha sido imparable: regeneración ósea, nuevos materiales bioactivos, osteointegración, son sólo ejemplos de un desarrollo que exige técnicas quirúrgicas complejas que son aplicadas cada vez con mayor frecuencia en la práctica clínica diaria.

Para poder llevar a cabo estos tratamientos de forma es imprescindible que el diagnóstico clínico, el radiológico y el nivel de conocimientos anatómicos esté en consonancia con los objetivos propuestos.

Lógicamente esta revolución tecnológica también ha afectado a los métodos de diagnóstico por imagen, cuyas innovaciones se han convertido en un complemento excepcional del diagnóstico clínico.

Para acabar este apartado de nuestra Tesis Doctoral, queremos resaltar que nuestro propósito con este desarrollo informático elaborado ha sido poner a disposición de los estudiantes y profesionales de la odontología una herramienta didáctica e interactiva que les permita obtener los conocimientos anatómicos más relevantes e imprescindibles para su actividad clínica profesional, a través de procedimiento tecnológico de visión tridimensional, que permite al usuario decidir la posición espacial que desea para analizar cualquier estructura anatómica del aparato dentario. 
CONCLUSIONES 
Después de generar una aplicación informática que visualiza, en tres dimensiones, los elementos anatómicos que integran el aparato dentario, a partir de secciones seriadas de Tomografías Computarizadas con tomógrafo multidetector, hemos llegado a las siguientes conclusiones:

$1^{\text {a }}$.- La técnica de Tomografía Computarizada optimizó la identificación de estructuras anatómicas del aparato dentario, constituyéndose como el método de imagen que mejor permitió identificar las estructuras óseas y dentarias. Su alta resolución de contraste permitió efectuar con precisión la delimitación anatómica de las estructuras del aparato dentario, en los cortes tomodensitométricos, lo que facilitó la posterior reconstrucción tridimensional.

$2^{\text {a }}$.- Los entornos virtuales de formación médica, con programas informáticos como el que hemos desarrollado, constituyen sin duda, una forma nueva de tecnología formativa, donde el aprovechamiento de todo este potencial tecnológico, es de gran utilidad en la práctica clínica, tal y como se ha demostrado tras su valoración en diferentes profesionales.

$3^{\mathrm{a}}$.- Las novedosas técnicas informáticas de grafismo por ordenador, que hemos empleado en nuestro estudio, han permitido desarrollar imágenes tridimensionales muy próximas a la realidad, tomando una nueva entidad en el ámbito de la odontología, al posibilitar la creación y manipulación de imágenes anatómicas de estructuras del aparato dentario, originando un entorno virtual de visualización en cualquier posición espacial, con fines docentes y prácticos.

$4^{\text {a }}$.- El procedimiento informático elaborado es totalmente innovador, facilitando la comprensión y aprendizaje de la anatomía del aparato dentario, posibilitando 
así, de una manera atractiva, dinámica e interactiva, la adquisición de los conocimientos necesarios de los principales elementos anatómicos del aparato dentario, necesario para la labor profesional en el campo de la odontología, tal y como se desprende de los resultados de las encuestas de satisfacción efectuadas.

$5^{\mathrm{a}}$.- El desarrollo informático realizado, permite experimentar con medios que se ajusten a nuestra realidad en el área de la odontología, por lo que al diseñar entornos virtuales para la formación docente y experiencia práctica de la anatomía, ayudará al usuario a situarse, de forma simulada, ante situaciones reales.

$6^{\text {a }}$ - Nuestro sistema informático, se maneja a voluntad del usuario, por lo que existe una verdadera interacción entre éste y el ordenador, evitando así, en la medida de lo posible, que el usuario se convierta en un mero espectador; pudiendo visualizar una imagen en la posición que desee y con las estructuras anatómicas del aparato dentario que considere oportunas; lo que le da una gran libertad de posibilidades de observación, cosa que no ofrecen otros dispositivos de formación como los atlas anatómicos.

$7^{\text {a }}$ y última.- La incorporación de las tecnologías informáticas al campo de la formación superior, supone un recurso útil y atractivo para la docencia de cualquier área de las ciencias de la salud. Hemos podido reflejar, que la formación, con el apoyo de métodos tecnológicos y programas informáticos interactivos como el que hemos elaborado, favorece sin duda el proceso de aprendizaje, estimulando al usuario en la consecución de objetivos docentes, como se ha demostrado y valorado con nuestro procedimiento tecnológico desarrollado. 


\section{BIBLIOGRAFIA}


ABU-SERRIAH, M.M.; AYOUB, A.F.; ODELL, E.; CARMICHAEL, S. y WRAY, D. (2004). A minimally invasive novel design for a vascular-pedicled bone segment for experimental studies of reconstruction of mandibular defects. $\mathrm{Br} \mathrm{J}$ Oral Maxillofac Surg, 42: 236-240.

ACERO, J. y SOMACARRERA, M.L. (1998). Lesiones radiolúcidas de los maxilares. En Bascones, A. y cols.: Tratado de Odontología, III: 2893-909. Trigo Ediciones. Madrid.

ACKERMAN, MJ.; RIFKIN, BA y FOLKENBERG, J. (2006). Human Anatomy. Depicting the Body from the Renaissance to Today. Thames \& Hudson.

ADAMS, L.; KRYBUS, W. y MEYER-EBRECHT, D. (1990). Computer-Assisted Surgery. IEEE Comput Graphics App, 10: 43-51.

AGUIRRE, J.M. y CABALLERO, R. (1995). Diagnóstico diferencial de las lesiones radiotransparentes de los maxilares. En BAGAN, J.V. y cols.: Medicina Oral. Masson. Barcelona.

ALANDEZ, J.; HERRERA, J.I. y CARASOL, M. (1996). El diagnóstico radiológico en la planificación del tratamiento con implantes. RCOE, 4: 23-30.

ALbERICO, R.A.; LOUD, D.; POLlINE, J.; GRECO, W.; PATEL, M. y KLUFAS, R. (2000). Thick section reformatting of thinly collimated helical CT for reduction of skull base-related artifacts. Am J Roentgol, 175: 1361-1366.

ALEXANDER, J.M. (1976). Radionuclide bone scanning in the diagnosis of lesions of the maxillofacial region. J Oral Surg, 34: 249.

ALHAIJA, E.S. (2005). Panoramic radiographs: determination of mandibular steepness. J Clin Pediatr Dent, 29 : 165-166.

ALVAREZ, M. (1984). Informática para docentes. Anaya. Madrid.

ANDERSON, JG. y JAY, JS. (1987). Use and impact of computers in clinical medicine. New York, Springer-Verlag.

APS, J.K.M. (2010).Flemish general dental practitioners' knowledge of de dental radiology. Dentomaxillofacial Radiology. 39: 113-118. 
ARAI, Y.; TAMMISALO, E.; IWAI, K.; HASHIMOTO, K. y SHINODA, K. (1999). Development of a compact tomographic apparatus for dental use.

Dentomaxillofacial Radiology. 28:245-8.

ARANA-FERNÁNDEZ DE MOYA, E.; BUITRAGO-VERA, P.; BENETIRANZO, F. y TOBARRA-PÉREZ, E. (2006). Tomografía computerizada: introducción a las aplicaciones dentales. RCOE. 11:311-322.

ASENSIO M. (2005). Imaginología de la cavidad bucal: estudio anatomo-radiológico. Tesis Doctoral Universidad de Salamanca.

AVOLIO de COLS, S. (1981). Planeamiento del Proceso de Enseñanza-Aprendizaje. Ediciones Marymar S.A.. Buenos aires.

BABA, R.; UEDA, K. y OKABE, M. (2004). Using a flat-panel detector in high resolution cone beam CT for dental imaging. Dentomaxillofac Radiol, 33 (5): 285-90.

BAGAN, J.V.; CEBAlloS, A.; BERMEJO, A.; AGUIRRE, J.M. y PEÑARROCHA, M. (1995). Medicina Oral. Masson. Barcelona.

BAJKA, M.; MANESTAR, M.; HUG, J.; SZÉKELY, G.; HALLER, U. y GROSCURTH, P. (2004). Detailed anatomy of the abdomen and pelvis of the visible human female. Clin Anat, 17: 252-260.

BAKKER, AR.; BALL, M.J.; SCHERRER, J.R. y WILLEMS, J.L. (1988). Towards New Hospital Information System, Noth-Holland Publ. Comp. Amsterdam

BARTOLOMÉ, A. (1989). Nuevas tecnologías y Enseñanza. Graó-ICE UB. Barcelona.

BASCONES, A. y LLANES, F. (1996). Medicina bucal. Ed. Avances. Madrid.

BASDOGAN, L.; HO, H.; SRINIVASAN, S.; SMALL, P. Y DAWSON, J. (1998). Force Interactions in Laparoscopic Simulations: Haptic Rendering of Soft Tissues. Proceedings of the Medicine Meets Virtual Reality Conference, San Diego,CA, Ja.

BECCARÍA, L.P. y REY, P.E. (1999). La inserción de la Informática en la Educación y sus efectos en la reconversión laboral". Instituto de Formación Docente SEPA-. Buenos Aires.

BERNSTEIN, E. F. (1978). Non invasive diagnostic Techniques in vascular disease. Mosby. St. Louis.

BERNSTEIN, E. F. (1990). Recent advances in non invasive diagnostic techniques in vascular disease. Mosby. St. Louis.

BLANCO, A.; BASCONES, A. y LLANES, F. (1998). Patología lingual. En Bascones, A. y cols.: Tratado de Odontología, III: 3195-206. Trigo Ediciones. Madrid. 
BOET, S.; BOULD, M.D.; BURN, C.L. y REEVES, S. (2014). Twelve tips for a successful interprofessional team-based high-fidelity simulation education session. Medical Teacher.1-5, Early Online.

CARLSON, B.M. (2006). Embriología humana y Biologia del desarrollo. $3^{\text {a }}$ Edición. Elsevier. Madrid.

CARMICHAEL SW, PAWLINA W. (2000). Animated Power-Point as a tool to teach anatomy. Anat Rec (New Anat), 261: 83-88.

CARRANZA, F.A. (1990). Glickman’s Clinical Periodontology. Saunders. Filadelfia.

CASTILLEJO, J.L. (1986). Tecnología y Educación. CEAC. Barcelona.

CHIRANI, R.A.; JACQ, J.J.; MERIOT, P. y ROUX, C. (2004). Temporomandibular joint: a methodology of magnetic resonance imaging 3-D reconstruction. Oral Surg Oral Med Oral Pathol Oral Radiol Endod. 97: 756-61.

CHUNG, M.S.; KIM, M.K.y PARK, S.K. (2000). Three-dimensional virtual dissection program of the heart using Korean cadaver. J Biomed Eng Res, 21:17-22.

CLARK, H.C. y CURZON, M.E. (2004). A prospective comparison between findings from a clinical examination and results of bitewing and panoramic radiographs for dental caries diagnosis in children. Eur J Paediatr Dent. 5 (4): 203-9.

CONTRERAS, D.J. (1990). Enseñanza, Currículum y Profesorado. "Introducción crítica a la Didáctica". Ed. Akal. Buenos Aires. 1990.

COTIN, S.; DELINGETTE, H. y AYACHE, N. (1996). Real time volumetric deformable models for surgery simulation. Visualizatin in Biomedical Computing (Proc. VBC'96). Höhne KH, Kikinis R (eds.). Lecture Notes in Computer Science, vol. 1131, Springer-Verlag.

COTTON, T. P.; GEISLER, T.M.; HOLDEN, D.T.; SCHWARTZ, S.A. y SCHINDLER, W.G. (2007). Endodontic applications ofcone-beam volumetric tomography. J Endod. 9: 1121-1132.

COVA, M.; UKMAR, M.; BOLE, T.; MORRA, A.; LUBIN, E. y POZZI MUCELLI, R. (2003). Evaluation of lingual vascular canals of the mandible with Computed Tomography. Radiol Med (Torino). 106 (4): 391-8.

CUENA, J. (1986). Inteligencia artificial: sistemas expertos. Alianza. Madrid.

DE PABLOS, J. y GORTARI, C. (1992). Las nuevas tecnologías de la información en la educación. Alfar. Sevilla.

DEUTSCH JC. (2006). Applications of the Colorado Visible Human Project in Gastroenterology. Clin Anat, 19: 254-257. 
DONADO, M.; DONADO, A.; GUISADO, B.; ORTEGA, R. y SANZ, J.V. (2003). Anatomía Implantológica: Bases morfológicas y su aplicación clínica en Implantología dental. Ars Médica STM Editores. Barcelona.

DOWNES, M.; HSU, A. y STEELE, M. (1997). A virtual environment for training laparoscopic chiolecystectomy. Univ. California. Berkeley CS294-5, Virtual Reality, spring Semester.

DRAKE RL. (1998). Anatomy education in a changing medical curriculum. Anat Rec (New Anat), 253: 28-31.

DUMOULIN, S.O.; HOGE, R.D.; BAKER, C.L. JR.; HESS, R.F.; ACHTMAN, R.L. y EVANS, A.C. (2003). Automatic volumetric segmentation of human visual retinotopic cortex. Neuroimage, 18:576-587

ECKHOFF, D.G.; BACH, J.M.; SPITZER, V.M.; REINING, K.D.; BAGUR, M.M.; BALDINI, T.H.; RUBINSTEIN, D. y HUMPHRIES, S. (2003). Threedimensional morphology and kinematics of the distal part of the femur viewed in virtual reality. Parte II. J Bone Joint Surg Am. 85 (Suppl 4): 97-104

EMMOTT, L.F. (2005). The digital revolution, images and X-rays. N Y State Dent J, 71 (1): 40-3.

ENLOW, D.H. y HANS, M.G. (1998). Crecimiento facial. Mc Graw-Hill Interamericana. Madrid.

ENRIQUEZ, F. y MARTÍNEZ, D. (1991). Metodología para la informatización de la historia clínica. Madrid, Rama.

ERTEN, H.; AKARSLAN, Z.Z. y TOPUZ, O. (2005). The efficiency of three different films and radiovisiography in detecting approximal carious lesions. Quintessence Int, 36: 65-70.

ESTEVEZ, R.; DE LA TORRE, F.; ARANGUREN, J.; TEJEDOR, B y CISNEROS R. (2009). Tomografía computarizada en endodoncia: usos e indicaciones. Endodoncia, 27: 80-85.

EVE, E.J.; KOO, S.; ALSHIHRI, A.A.; CORMIER, J.; KOZHENIKOV, M.; DONOFF, R.B. KARIMBUX N.Y. (2014). Performance of Dental Students Versus Prosthodontics Residents on a 3D Immersive Haptic Simulator. J Dent Educ, 78:630637

FIELDING, J.R.; DUMANLI, H.; SCHEEYER, A.G.; OKUDA, S.; GERING, D.T.; ZOU, K.H.; KIKINIS, R. y JOLESZ, F.A. (2000). MR-based threedimensional modeling of the normal pelvic floor in women: quantification of muscle mass. AJR Am J Roentgenol. 174(3):657-660.

FIELDING, JR. (2002). Practical MR imaging of female pelvic floor weakness. Radiographics. 22: 295-304. 
FIESCH, M. (1987). Inteligencia artificial en medicina. Sistemas expertos. Barcelona, Masson.

GAMBA, D.; RAYMUNDO, R.; VASCONCELLOS, M.; VASCONCELLOS, D. y NIZA, S. (2007).Tomografía computadorizada de feixe cônico (Cone beam): entendendo este novo método de diagnóstico por imagem com promisora aplicabilidade na Ortodontia. Rev. Dent. Ortodon Ortop Fac.12: 139-156.

GARG, A.; NORMAN, G.; SPERO, L. y TAYLOR, I. (1999). Learning anatomy: do new computer models improve spatial understanding. Med Teacher. 21: 519-522.

GEHRMANN, S.; HÖHNE, K.H.; LINHART, W.; PFLESSER, B.; POMMERT, A.; RIEMER, M.; TIEDE, U.; WINDOLF, J.; SCHUMACHER, U. y RUEGER, J.M. (2006). A Novel Interactive Anatomie Atlas of the Hand. Clin Anat. 19: 258-266.

GERVÁS, J.J. (1987). Los sistemas de registro en la atención primaria de salud. Madrid, Díaz de Santos.

GIBSON, S.; SAMOSKY, J. Y MOR, A. (1997). Simulating arthroscopic knee surgery using volumetric object rendering with real-time volume rendering. In: CVMRMed- MRCAS'97, 369-378. Springer-Verlag.

GIJBELS, F.; SANDERINK, G.; WYATT, J.; VAN DAM, J.; NOWAK, B. y JACOBS, R. (2004). Radiation doses of indirect and direct digital cephalometric radiography. Br Dent J. 197 (3): 149-52.

GLOVER, G.H. y EISNER, R.L. (1979). Theoretical resolution of computed tomography systems. J Comput Assist Tomogr. 3: 85-91.

GLOVER, G.H. y PELC, N.J. (1980). Nonlinear partial volume artifacts in X-ray computed tomography. Med Phys. 7: 238-249.

GOAZ, P.W. y WHITE, S.C. (1995). Radiología oral. Principios e interpretación. Mosby-Doyma. Madrid.

GOGA, R.; CHANDLER, N.P. y LOVE, R.M. (2004). Clarity and diagnostic quality of digitized conventional intraoral radiographs. Dentomaxillofac Radiol, 33 (2): 103-7.

GOH, V.; HALLIGAN, S.; KAPLAN, G.; HEALY, J.C. y BARTRAM, C. (2000). Dynamic MR imaging of the pelvic floor in asymptomatic subjects. AJR. 174: 661-666.

GOMEZ, M.E. y CAMPOS; A. (2000). Histología y Embriología Bucodental. Editorial Médica Panamericana. Madrid.

GUERRERO, M.E.; JACOBS, R.; LOUBELE, M.; SCHUTYSER, F.; SUETENS, P. Y VAN STEENBERGHE, D . (2006). State of the art on cone beam CT imaging for preoperative planning of implant placement. Clin O ral Invest, 10: 1-7.

GUTIÉRREZ C. (1997). Medicina e Internet. Anaya Multimedia.A.A. Madrid. 
HAJEER, M.Y.; MAO, Z.; MILLETT, D.T.; AYOUB, A.F. y SIEBERT J.P. (2005). A new three-dimensional method of assessing facial volumetric changes after orthognathic treatment. Cleft Palate Craniofac J. 42: 113-20.

HALLGREN, R.C.; PARKHURST, P.E.; MONSON, C.L. y CREWE, N.M. (2002). An interactive, web-based tool for learning anatomic landmarks. Acad Med, 77: 263265.

HAMADA, Y.; KONDOH, T.; NOGUCHI, K.; IINO, M.; ISONO, H.; ISHII, H.; MISHIMA, A.; KOBAYASHI, K. y SETO, K. (2005). Application of limited cone beam computed tomography to clinical assessment of alveolar bone grafting: a preliminary report. Cleft Palate Craniofac J. 42 (2): 128-37.

HANAZAWA, T.; SANO, T.; SEKI, K. y OKANO, T. (2004). Radiologic measurements of the mandible: a comparison between CT-reformatted and conventional tomographic images. Clin Oral Implants Res. 15:226-32.

HASSAN B. (2010). Comparison of Five Cone Beam Computed Tomography Systems for the Detection of Vertical Root Fractures. J Endod. 36:126-29.

HASSAN, B.; METSKA, M.E.; OZOK, A. R.; VAN DER STELT, P. y WESSELINK, P.R. (2009). Detection of vertical root fractures in endodontically treated teeth by cone beam computed tomography scan. J. Endod. 35:719-22.

HATFIELD, P.; TEMKIN， B.; GRISWOLD，JA.; DEEB，SA.; DEV，P.; HEINRICHS, WL.; SRIVASTAVA, S. y WALDRON K. (2002). Volumetric virtual body structures. Stud Health Technol Inform. 85: 185-187.

HEGE, I.; ZARY, N. y KONONOWICZ, A.A. (2012). Criteria to assess the quality of virtual patients. Stud Health Technol Inform., 180:954-7.

HERNANDEZ, G. (1998). Radiología periodontal. En Bascones, A. y cols.: Tratado de Odontología. III: 2881-91. Trigo Ediciones. Madrid.

HIRSCHMANN, P.H. (1998). Magnetic resonance imaging. A possible alternative to CT prior to dental implants. Br Dent J. 12: 600.

HOFFMAN, H. y MURRAY, M. (1999). Anatomic visualizer: Rendering the vision of a VR-based learning enviorement. Medicine Meets Virtual Reality, 7: 134-140.

HOFFMANN, J.; WESTENDORFF, C.; LEITNER, C.; BARTZ, D. y REINERT, S. (2005). Validation of 3D-laser surface registration for image-guided craniomaxillofacial surgery. J Craniomaxillofac Surg. 33 (1): 13-8.

HORCH, H.H.; BECKER, R.; GUNDLACH, K.K.H.; HAUSAMEN, E.; HERZOG, M.; JOOS, U.; REICH, R.; SCHMIDT, P.A. y SPITZER, W.J. (1995). Cirugía Oral y Maxilofacial. Masson. Barcelona.

HOUNSFIELD, G.N. (1973). Computerized transverse axial scanning (tomography). Part. 1. Description of system. Br J Radiol. 46: 1016-1022. 
HOYTE, L.; SCHIERLITZ, L.; ZOU, K.G. y FLESHG, J. (2001). Two- and 3dimensional MRI comparison of levator ani structure, volume, and integrity in women with stress incontinence and prolapse. Am J Obstet Gynecols.,;185(1):11-19.

IMAMURA, H.; SATO, H.; MATSUURA, T.; ISHIKAWA, M. y ZEZE, R. (2004). A comparative study of computed tomography and magnetic resonance imaging for the detection of mandibular canals and cross-sectional areas in diagnosis prior to dental implant treatment. Clin Implant Dent Relat Res. 6 (2): 75-81.

INOSTROZA P. (2005). Real-time update of eye features on the 3D head model texture. Comp. Anim Virtual Worlds. 16: 129-136.

JASHTROW, H. y VOLLRATH, L. (2002). Anatomy online: Presentation of a detailed WWW atlas of human gross anatomy-reference for medical education. Clin Anat. 15: 402-408.

JIMÉNEZ, B.; GONZÁLEZ, A.P.; y FERRERES,V. (1989). Modelos didácticos para la innovación educativa. PPU. Barcelona.

JOSEPH, P.M. (1981). Artifacts in computed tomography. En: Newton, T.H. y Potts, D.G.: Radiology of the skull and brain: technical aspects of computed tomography. 5: 3956-3992. Mosby. St.Louis.

JOSEPH, P.M. y SPITAL, R.D. (1978). A method for correcting bone induced artifacts in computed tomography scanners. J Comput Assist Tomogr. 2: 100-108.

JUANES, J.A.; PRATS, A.; LAGÁNDARA, M.L. y RIESCO, J.M. (2003). Application of the «Visible Human Project» in the field of anatomy: a review. European Journal of Anatomy,7:147-159.

JUANES, J.A.; ESPINEL, J.L.; VELASCO, M.J.; ZOREDA, J.L.; RIESCO, J.M.; CARMENA, J.J.; BLANCO, E.; MARCOS, J. y VAZQUEZ, R. (1996). A threedimensional virtual model of the head generated from digitalized CT or MR images for anatomical-radiological and neurosurgical evaluations. J Neuroradiol, 23(4): 211-6.

KAU C, RICHMOND S. (2005). Three-dimensional cone beam computerized tomography in orthodontics. J. Orth.; 32: 282-293.

KATSUMATA, A.; FUJISHITA, M.; MAEDA, M.; ARIJI, Y.; ARIJI, E. y LANGLAIS, R.P. (2005). 3D-CT evaluation of facial asymmetry. Oral Surg Oral Med Oral Pathol Oral Radiol Endod. 99: 212-20.

KERR, J.P.; RATIU, P. y SELLBERG, M. (1996). Volume rendering of visible human data for an anatomical virtual environment. Stud Health Technol Inform, 29: $352-370$.

KHAN, E.A.; TYNDALL, D.A. y CAPLAN, D. (2004). Extraoral imaging for proximal caries detection: Bitewings vs scanogram. Oral Surg Oral Med Oral Pathol Oral Radiol Endod. 98: 730-7. 
KIM, H.J.; YOON, H.R.; KIM, K.D.; KANG, M.K.; KWAK, H.H.; PARK, H.D.; HAN, S.H. y PARK, C.S. (2003). Personal-computer-based three-dimensional reconstruction and simulation of maxillary sinus. Surg Radiol Anat. 24: 393-9.

KING, A.E.; CONRAD, M. y AHMED, R.A. (2013). Improving collaboration among medical, nursing and respiratory therapy students through interprofessional simulation. $\mathbf{J}$ Interprof Care. 27:269-271.

KITAI, N.; ERIKSSON, L.; KREIBORG, S.; WAGNER, A. y TAKADA, K. (2004). Three-dimensional reconstruction of TMJ MR images: a technical note and case report. Cranio. 22 (1): 77-81.

KONONOWICZ, A.A.; HEGE. I.; KRAWCZYK, P. y ZARY, N. (2012). New approaches to linking clinical guidelines to virtual patients. Stud Health Technol Inform.180:958-962.

KORALAKUNTE, P.R. y ALJANAKH, M. (2014). The role of Virtual Articulator in Prosthetic and Restorative Dentistry. Journal of Clinical and Diagnostic Research. 8: 25-28

KOTTOO, J.; HEMAMALATHI, S.; SUDHA, R. y VELMURUGAN, N. (2010). Maxillary second molar with 5 roots and 5 canals evaluated using cone beam computerized tomography: a case report. Oral Surg Oral Med Oral Pathol Oral Radiol Endod. 109: 162-165.

KRAUS, P. y LUFKIN, T. (1999). Mammalian Dlx homeobox gene control of craniofacial and inner car morphogenesis. J cell Biochem suppl. 32: 133-140.

LA, S.; JUNG, D.; KIM, E. MIN, K. (2010). Identification of independent middle mesial canal in mandibular first molar using cone-beam computed tomography Imaging. J Endod. 36:542-245.

LAMICHANE, M.; ANDERSON, N. K.; RIGALI, P.H.; SELDIN, E.B. y WIL, LA. (2009). Accuracy of reconstructed images from cone-beam comuted tomography scans. Am J. Orthod J Dentofacial Orthop, 136: 156-157.

LARSEN, W.J. (2006). Human Embryology. Chruchill Livingstone. Nueva York.

LEE, J.Y.; HAN, Q. y TROTMAN, C.A. (2004). Three-dimensional facial imaging: accuracy and considerations for clinical applications in orthodontics. Angle Orthod. 74: 587-93.

LEE, S.S.; CHOI, J.H.; YOON, C.L.; KIM, C.Y. y SHI, K.J. (2004). The diversity of dental patterns in the orthopantomography and its significance in human identification. J Forensic Sci. 49: 784-6.

LEGOVIC, M; PAPA, D.; LEGOVIC, A.; MARIC, M. y LAPTER, M. (2004). Verifica dell'asimmetria mascellare e mandibolare tramite analisi di ortopantomografia. Minerva Stomatol. 53: 369-74. 
LENGUAS, A.L.; ORTEGA, R.; SAMARA, G. Y LÓPEZ, M.A. (2010).

Tomografía computerizada de haz cónico.Aplicaciones clínicas en odontología; comparación con otras técnicas. Cient Dent ,7:147-159.

LI, L.; LIU, Y.X. y SONG, Z.J. (2006). Three-Dimensional Reconstruction of Registered and Fused Chinese Visible Human ans Patient MRI Images. Clin Anat. 19: 225-231.

LUCAS, M.; SOMACARRERA, M.L.; LOPEZ, A. y HERNANDEZ, G. (1998). Lesiones radiológicas mixtas de los huesos maxilares. En Bascones, A. y cols.: Tratado de Odontología. III: 2919-30. Trigo Ediciones. Madrid.

LUND, B.; FORS, U.; SEJERSEN, R.; SALLNÄS, E.L. y ROSÉN, A. (2011). Students perception of two different simulation techniques in oral and maxillofacial surgery undergraduate training. BMC Med Educ 11: 82-84

MACORRA, J.C. (1998). Diagnóstico radiológico de las enfermedades dentarias. En Bascones, A. y cols.: Tratado de Odontología, III: 2931-38. Trigo Ediciones. Madrid.

MANCUSO, A.A. y HANAFEE, W.N. (1985). Computed tomography and magnetic resonance imaging of the head and neck. Williams and Wilkins. Baltimore.

MARQUÉS, P. (1999). "El software educativo". Universidad de Barcelona. España. 1999.

MARTINEZ, J.M. (1998). Lesiones radiocondensantes. En Bascones, A. y cols.: Tratado de Odontología. III: 2911-2918. Trigo Ediciones. Madrid.

MARTINEZ, C. y LINARES, R. (1998). Embriología. En Bascones, A. y cols.: Tratado de Odontología. I: 243-289. Trigo Ediciones. Madrid.

MARTÍNEZ DE IBARRETA ZORITA, J. (2008). Modelización virtual de la pelvis femenina, a partir de imágenes de resonancia magnética. Tesis Doctoral. Universidad de Salamanca.

MARTIN-GRANIZO, R. y GARCIA-GONZÁLEZ, D. (2004). Unilateral agenesis of the parotid gland: a case report. Oral Surg Oral Med Oral Pathol Oral Radiol Endod. 98 (6): 712-4.

MILLER, S.A.; PERROTTI, W.; SILVERTHORN, D.U.; DALLEY, A. y RAREY, K. (2002). From college to clinic: Reasoning over memorization is key for understanding anatomy. Anat Rec (New Anat), 269: 69-80.

MOLANDER, B.; GRÖNDAHL, H.G. y EKESTUBBE, A. (2004). Quality of filmbased and digital panoramic radiography. Dentomaxillofac Radiol. 33 (1): 32-6.

MONSOUR, P.A y DUDHIA, R. (2008). Implant radiography and radiology. Aust Dent J, 2008; 53(1)s11-25.

MONTSERRAT, C. (1999). Modelos deformables de tejidos elásticos en tiempo real. Tesis Doctoral, Universidad Politécnica de Valencia, septiembre de 1999. 
MONSERRAT, C.; ALCAÑIZ, M.; MEIER, U.; POZA, J.; JUAN, M. y GRAU, V. (2000). Simulador para el entrenamiento en cirugías avanzadas. Universidad Politécnica de Valencia. www.dsic.upv.es/ cmonserr/Articulos/AA028 pdf.

MOORE, K.L. y PERSAUD, T.V.N. (1995). Embriología clínica 5ª Ed. McGraw-HillInteramericana. Méjico.

MORIMOTO, Y.; TANAKA, T.; KITO, S.; TOMINAGA, K.; YOSHIOKA, I.; YAMASHITA, Y.; SHIBUYA, T.; MATSUFUJI, Y.; KODAMA, M.; TAKAHASHI, T.; FUKUDA, J. y OHBA, T. (2005). Utility of three dimension fast asymmetric spin-echo (3D-FASE) sequences in MR sialographic sequences: model and volunteer studies. Oral Dis. 11 (1): 35-43.

MOZZO, P.; PROCACCI, C.; TACCONI, A.; MARTINI, P.T. y ANDREIS, I.A. (1999). A new volumetric CT machine for dental imaging base done the cone-beam technique: preliminary results. European Radiology. 8: 1558-1564.

MUÑOZ, J.V.; SOLER, F.; PEÑARROCHA, M. y GUARINOS, J. (1998). Estudio entre osteometría directa, tomografía computarizada y radiografía panorámica. RCOE. 1: 25-31.

MUPPARAPU, M. y SINGER, S.R. (2004). Implant imaging for the dentist. J Can Dent Assoc, 70: 32-37.

NAKASIMA, A.; TERAJIMA, M.; MORI, N.; HOCINO, Y.; TOKUMORI, K.; AOKI, Y. y HASHIMOTO, S. (2005). Three-dimensional computer-generated head model reconstructed from cephalograms, facial photographs, and dental cast models. Am J Orthod Dentofacial Orthop. 127: 282-92.

NKENKE, E.; ZACHOW, S.; BENZ, M.; MAIER, T.; VEIT, K.; KRAMER, M.; BENZ, S.; HÄUSLER, G.; NEUKAM, F.W. y LELL, M. (2004). Fusion of computed tomography data and optical 3D images of the dentition for streak artefact correction in the simulation of orthognathic surgery. Dentomaxillofac Radiol. 33: 226329.

OKANO, Y.; YAMASHIRO, M.; KANEDA, T. y KASAI, K. (2003). Magnetic resonance imaging diagnosis of the temporomandibular joint in patients with orthodontic appliances. Oral Surg Oral Med Oral Pathol Oral Radiol Endod. 95: 255263.

ORTEGA, P. y MARTINEZ, F. (1994). Educación y Nuevas Tecnologías. Paraninfo. Madrid

ORTEGA, R. (1998). Anatomía radiográfica de la cavidad oral. Técnicas de exploración. En: Bascones, A. y cols. Tratado de Odontología. Trigo Ediciones, 28672880. Madrid.

OVIEDO MUÑOZ, P.Y HERNÁNDEZ-AÑÃ̃OS, J.F. (2012). Tomografía computarizada Cone Bean en endodoncia. Rev Estomatol Herediana. 22: 59-64.

PAALMAN M. (2000). New frontiers in Anatomy Education. Anat Rec (New Anat), 261: 247. 
PALOMO, J.M.; WOLF, G.R. y HANS, M.G. (2004). Use of digital photography in the Case orthodontic clinic. Am J Orthod Dentofacial Orthop. 126: 381-385.

PAPADOPOULOS L. (2010). Virtual reality simulators in dental training. Hel Stom. Rev. 54:263-276

PARIKH, M.; RASMUSSEN, M.; BRUBAKER, L.; SALOMON, C.; SAKAMOTO, K.; EVERHOUSE, R., AI, Z. y DAMASER M.S. (2004). Threedimensional virtual reality model of the normal female pelvic floor. Ann Biomed Eng. 32:292-296.

PARK, JS.; CHENG, M.S.; HWANG, S.B.; LEE, Y.S.; HAR, D.H. y PARK, H.S. (2005). Visible Korean human: Improved serially sectioned images of the entire body. IEEE Trans Med Imaging. 24: 352-360.

PARK, J.S.; CHENG, M.S.; HWANG, S.B.; SHIN, B.S. y PARK, H.S. (2006). Visible Korean Human: Its Techniques and Applications. Clin Anat. 19: 216-224.

PASLER, F.A. (1992). Atlas de Radiología Odontológica. Masson-Salvat. Barcelona.

PASQUET, G. y CAVEZIAN, R. (1993). Diagnóstico por la imagen en odontoestomatología. Masson. Barcelona.

PATEL, S.; DAWOOD, A. y WHAITES, E. (2009). New dimensions in endodontic imaging: Part 1 Conventional and alternative radiographic systems. Int End J. 42: 447462.

PEREIRA, J.A.; MERÍ, A.; MOLINA-ROS, A. y MOLINA-ANDREU, O. (2003). Web-based course for teaching Human Anatomy. The UPF experience. Eur. J Anat. 7: 19-22.

PFLESSER, B.; PETERSIK, A.; POMMERT, A.; RIEMER, M.; SCHUBERT, R.; TIEDE, U.; HOHNE, K.H.; SCHUMACHER, U. y RICHTER, E. (2001). Exploring the visible human's inner organs with the Voxel-Man 3D navigator. Stud Health Technol Inform. 81: 379-385.

PLATZER W. (1995). Pernkopf Anatomía. V.2. Marban. Madrid.

PODESSER, B.; WILliAMS, S.; BANTLEON, H.P. e IMHOF, H. (2004). Quantitation of transverse maxillary dimensions using computed tomography: a methodological and reproducibility study. Eur J Orthod. 26: 209-15.

POULTON T, CONRADI E, KAVIA S, ROUND J, HILTON S. (2009). The replacement of 'paper' cases by interactive online virtual patients in problem-based learning. Med Teach. 31:752-8.

RACHMIEL, A.; AIZENBUD, D.; PILlAR, G.; SROUJI, S. y PELED, M. (2005). Bilateral mandibular distraction for patients with compromised airway analyzed by three-dimensional CT. Int J Oral Maxillofac Surg. 34: 9-18.

REEVES, S. y VAN SCHAIK S. (2012). Simulation: A panacea for interprofessional learning? J Interprof Care. 26:167-169. 
REINDENBERG J.S. (2002). The new face of gross Anatomy. Anat Rec (New Anat), 269: 81-88.

RIVERA PORTO, E. (1993). La computadora en la educación. Ed. Publicaciones Portorriqueñas. San Juan.

ROBB, R.A. (1995). Three-dimensional biomedical imaging. Principles and practice. New Cork, NY: VCH Publishers, Inc. P 1-282.

ROBB, R.A. y SATAVA, R.M. (1997). Virtual endoscopy: Applications of 3-D visualization to medical diagnosis. Presence 6: 179-197.

ROBB, R.A. (2000). Virtual endoscopy: Development and evaluation using the Visible Human Datasets. Comput Med Imaging Graph. 24: 133-151.

ROBB, R.A. (2001). The biomedical imaging resource at Mayo Clinic. IEEE Trans Med Imaging, 20: 854-867.

ROBB, R.A. y HANSON, D.P. (2006). Biomedical Image Visualization Research Using the Visible Human Datasets. Clin Anat. 19: 240-253.

RODRÍGUEZ LAMAS, R. (2002). Introducción a la Informática Educativa. Ed. Pueblo y Educación, Ciudad de la Habana.

ROGER, F.H. y SANTUCCI, G. (1987). Perspectives of Information processing in Medica Applications. Berlín, Springer-Verlag.

ROMERO VACAS, J. (2005). Diseño, implementación y evaluación de un recurso multimedia para el aprendizaje de los fundamentos de la radiología odontológica. Tesis Doctoral. Universidad de Salamanca.

ROSEN, A.; ELIASSI, S.; FORS, U.; SALLNEAS, E.L.; FORSSLUND, J.; SEJERSEN, R. Y LUND, B. (2014). Computerised third molar surgery simulator results of supervision by different professionals. European J. of Dent Educ, 18:86-90

ROTHMAN, S. (1998). Dental aplications of computerized tomography. Surgical Planning for Implant Placement. Quintessence. Chicago.

ROUND, J.; CONRADI, E. y POULTON, T. (2009). Training staff to create simple interactive virtual patients: the impact on a medical and healthcare institution. Med Teach. 31:764-9.

ROYO, J. (2004). Diseño Digital. Ediciones Paidós Ibérica.

SADLER, T.W. (2006). Langman. Embriología Médica con orientación clínica. 10a edición. Edit. Medica Panamericana. Madrid.

SALINAS, J. (1994). Hipertexto e hipermedia en la enseñanza universitaria. Pixel-Bit. Revista de Medios y Educación. No1. Enero. pp. 15-29. 
SANTOS, B.F.; ENTER, D.; SOPER , N.J. Y HUNGNESS, E.S. (2011). Singleincision laparoscopic surgery (SILSTM) versus standard laparoscopic surgery: a comparison of performance using a surgical simulator. Surg. Endosc, 25: 483-490.

SATO, H.; MATSUGUMA, T.; ISHIKAWA, M.; KURAMOTO, S.; UKON, S.; ZEZE, R. y KODAMA, J. (2002). Deformation/displacement of posterior digastric and sternocleidomastoid muscles during posterior digastric muscle palpation using magnetic resonance imaging and image processing procedure. Journal of Oral Rehabilitation, 29(9): 884.

SCHENDEL, S.A. Y LANE, C. (2009). 3D Orthognatic Surgery simulation using image fusión. Semin Orthod, 15: 48-56.

SCHULZE, D.; HEILAND, M.; BLAKE, F.; ROTHER, U. y SCHMELZLE, R. (2005). Evaluation of quality of reformatted images from two cone-beam computed tomographic systems. J Craniomaxillofac Surg, 33 (1): 19-23.

SCHUBERT, R.; SCHIEMANN, T.; TIEDE, U. y HOHNE, K.H. (1997). Applications and perspectives in anatomical 3-dimensional modelling of the visible human with Voxel-Man. Acta Anat, 160: 123-131.

SCRIBANO, E.; ASCENTI, G.; MAZZIOTTI, S.; BLANDINO, A.; RACCHIUSA, S. y GUALNIERA, P. (2003). Computed tomography in dental implantology: medicolegal implications. Radiol Med (Torino), 105 (1-2): 92-9.

SEDAGHATFAR, M.; AUGUST, M.A. y DODSON, T.B. (2005). Panoramic radiographic findings as predictors of inferior alveolar nerve exposure following third molar extraction. J Oral Maxillofac Surg, 63 (1): 3-7.

SHIMIZU, M.; YOSHIURA, K.; NAKAYAMA, E.; KANDA, S.; NAKAMURA, S.; OHYAMA, Y. y NAKAMURA, N. (2005). Multiple sialolithiasis in the parotid gland with Sjögren's syndrome and its sonographic findings-report of 3 cases. Oral Surg Oral Med Oral Pathol Oral Radiol Endod, 99 (1): 85-92.

SHIRAI, Y y TSUJII, J. (1987). Inteligencia artificial. Conceptos, técnicas y aplicaciones. Ariel. Barcelona.Press.

SHNEIDERMAN, B. (1998). Designing The user interface, Strategies for effective Human-computer interaction. Addison-Wesley, 1998

SHORTLIFFE, E. y PERREAULT, L. (1990). Medical informatics: Computer applications in health care. Nueva York, Addison-Wesley, 1990

SILIO, M. y ARECHAGA, J. (1998). Desarrollo de la cavidad bucal y de los dientes. En Bascones, A. y cols.: Tratado de Odontología, I: 403-411. Trigo Ediciones. Madrid.

SPITZER, W.J. (1995). Nuevas posibilidades diagnósticas mediante técnicas de imagen. En HORCH, H.H. y cols.: Cirugía Oral y Máxilofacial, I: 3-36. Masson, SA. Barcelona. 
SPITZER VM, ACKERMAN MJ, SCHERZINGER AL, WHITLOCK DG. (1996). The visible human male: A technical report. J Am Med Inform Assoc, 3: 118-130.

SPITZER, V.M. y WHITLOCK, D.G. (1998). The Visible Human dataset: The anatomical platform for human simulation. Anat Rec (New Anat), 253: 49-57.

SPITZER, V.M. y SCHERZINGER, A.L. (2006). Virtual Anatomy: An Anatomist's Playground. Clinical Anatomy, 19: 192-203.

SUOMALAINEN, A.K.; SALO, A.; S ROBINSON, S. JS PELTOLA, J.S. (2007). The 3DX multi image micro-CT device in clinical dental practice. Dentomaxillofacial Radiology. 36:80-85.

TAYLOR, R.; LAVALLÉE, S.; BURDEA, G. Y MOSGES, R. (1996). Computerintegrated surgery. Technology and clinical applications. MIT Press, Cambridge MA.

TEMKIN, B.; ACOSTA, E.; HATFIELD, P.; ONAL, E. y TONG, A. (2002). Webbased three-dimensional Virtual Body Structures: W3D-VBS. JAMIA 9: 425-436.

TEMKIN, B.; ACOSTA, E.; MALVANKAR, A. y VAIDYANATH, S. (2006). An interactive three-dimensional virtual body structures system for anatomical training over the internet. Clin Anat. Apr;19:267-274.

TEMKIN, B.; STEPHENS, B.; ACOSTA, E.; WEI, B. y HATFIELD, P. (2000). Virtual body structures. En: Proccedings of the $3^{\text {rd }}$ visible human conference, Bethesda, Maryland.

TETRADIS, S.; ANSTEY, P. y GRAFF-RADFORD, S. (2010). Cone Beam Computed Tomography in the Diagnosis of Dental Disease. J Calif D ent A ssoc. 38: 27-32.

TRELEASE RB. (1998). Toward virtual anatomy: A stereoscopic 3-D interactive multimedia computer program for cranial osteology. Clin Anat, 9: 269-272.

TRELEASE, R.; NIEDER, G,; DORUP, J. y SCHACHT HANSEN M. (2000). Going virtual with quicktime VR: New methods and standardized tools for interactive dynamic visualization of anatomical structures. Anat Rec (New Anat), 261: 64-77.

TYNDALL, A.A. y BROOKS, S.L. (2000). Selection criteria for dental implant site imaging: a position paper of the American Academy of Oral and Maxillofacial radiology. Oral Surg. Oral Med. Oral Pathol. Oral Radiol. Endod. 89:630-7.

TYNDALL, DA. y RATHORE. S. (2008). Cone-Beam CT Diagnostic applications: Caries, periodontal bone assessment, and endodontic applications. Dent Clin North Am. 52(4):825-841.

VAN HOLSBEECK, M.T. e INTROCASO, J.H. (2002). Ecografía musculoesquelética. Marbán. Madrid. 
VARVARA, G.; ESPOSITO, P.; FRANCHINI, F.; PERINETTI, G. y CAPUTI, S. (2003). A positioning device for computed tomography: a clinical report. J Prosthet Dent, 89 (2): 123-6.

VÁZQUEZ R, RIESCO JM, JUANES JA, BLANCO E, RUBIO M, CARRETERO J. (2007). Educational strategies applied to the teaching of anatomy. The evolution of resources. Eur J Anat, 11 (supp 1) 31-43.

VERDASCO, M.; BRAVO, J.M.; GOMEZ, A. y MACORRA, J.C. (1994). Radiografías interproximales. Estudio clínico de su fiabilidad en la detección de caries interproximales de esmalte. Arch Odontoest Prev y Com, 10: 195-200.

VERHEY, J.F.; NATHAN, N.S.; RIENHOFF, O.; KIKINIS, R.; RAKEBRANDT, F. y D'AMBRA, M.N. (2006). Finite-element-method (FEM) model generation of time-resolved 3D echocardiographic geometry data for mitral-valve volumetry. Biomed Eng Online, 5:17.

WESTERMARK, A.; ZACHOW, S. y EPPLEY, B.L. (2005). Three-dimensional osteotomy planning in maxillofacial surgery including soft tissue prediction. J Craniofac Surg, 16: 100-4.

WIDMANN G. (2007). Image-guiided surgery and medical robotics in the cranial area. Biomed Imaging Interv J. 3:e11. doi: 10.2349/biij.3.1.e11

WINDISCH, G.; WEIGLEIN, A.H. y KIESLER, K. (2004). Herniation of the mylohyoid muscle. J Craniofac Surg, 15: 566-9.

WITKOWSKI GJ. (1890). La generación humana. C. Bailly-Bailliere Edit. Madrid.

YANAGISAWA, K.; FRIEDMAN, C.D.; VINING, E.M. y ABRAHAMS, J.J. (1993). Dentascan imaging of the mandibula and maxilla. Head and Neck. 15: 1-7.

ZARY, N.; JOHNSON, G. FORS, U. (2009). Web-based virtual patients in dentistry: factors influencing the use of cases in the Web-SP system. Eur J Dent Educ. 13:2-9. doi: 10.1111/j.1600-0579.2007.00470.x.

ZHANG, S.X.; HENG, P.A.; LIU, Z.J.; TAN, L.W.; QIU, M.G.; LI, Q.Y.; LIAO, R.X.; LI K, CUI GY, GUO YL, YANG XP, LIU GJ, SHAN JL, LIU JJ, ZHANG WG, CHEN XH, CHEN JH, WANG J, CHEN W, LU M, YOU J, PANG XL, XIAO H, XIE YM. (2003). Creation of the Chinese Visible Human data set. Anat Rec. 275B: 190-195.

ZHANG, SX.; HENG, P.A. y LIU, Z.J. (2006). Chinese Visible Human Project. Clinical Anatomy, 19: 204-215

ŻURADA A., GIELECKI J, JAN BARON, ZAWILIŃSKI JL Y KOZLOWSKA H. (2008). Interactive 3D stereoscopic digital-image analysis of the basilar artery bifurcation. Clinical Anatomy, 21: 127-137. 